Prepared in cooperation with the U.S. Environmental Protection Agency

\title{
Sources, Transport, and Trends for Selected Trace Metals and Nutrients in the Coeur d Alene and Spokane River Basins, Northern Idaho, 1990-2013
}
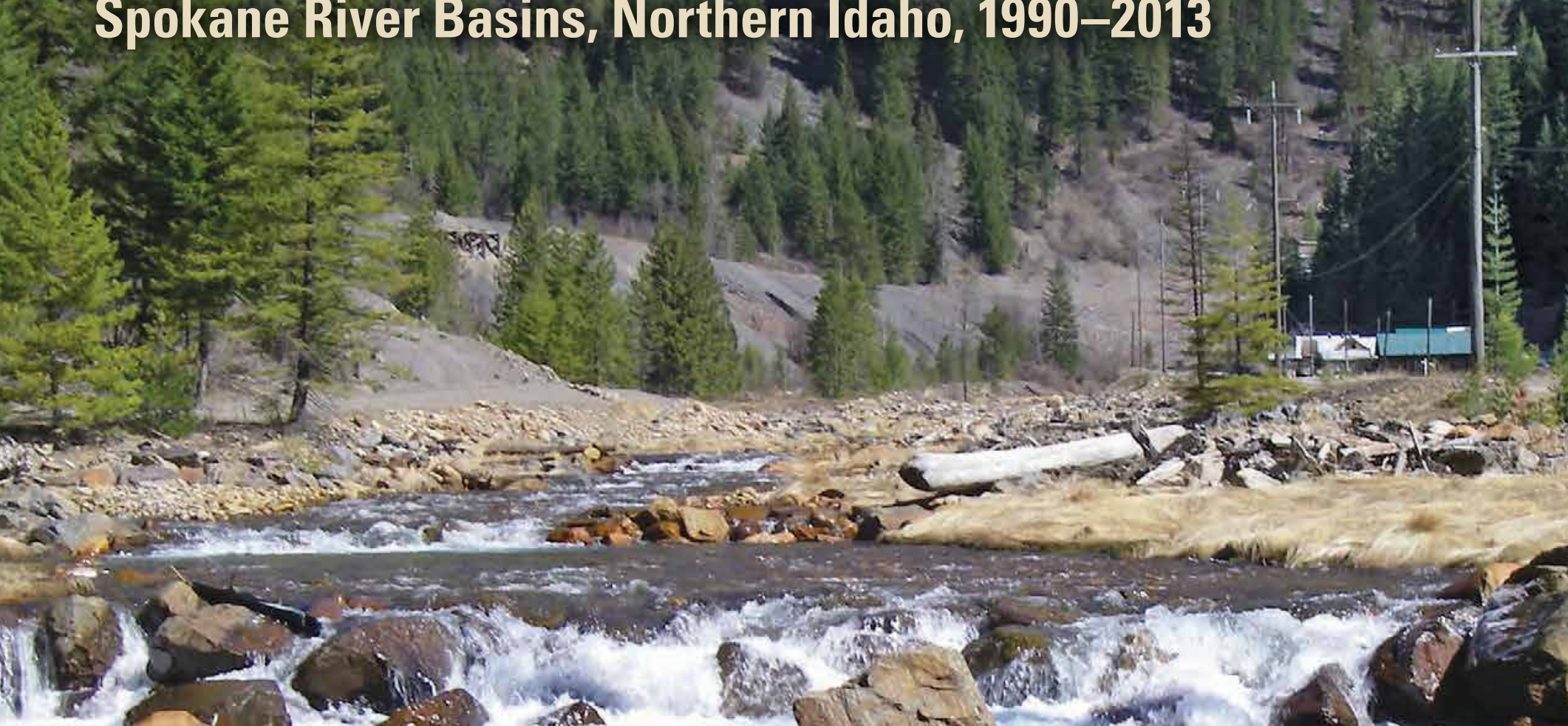

ativ
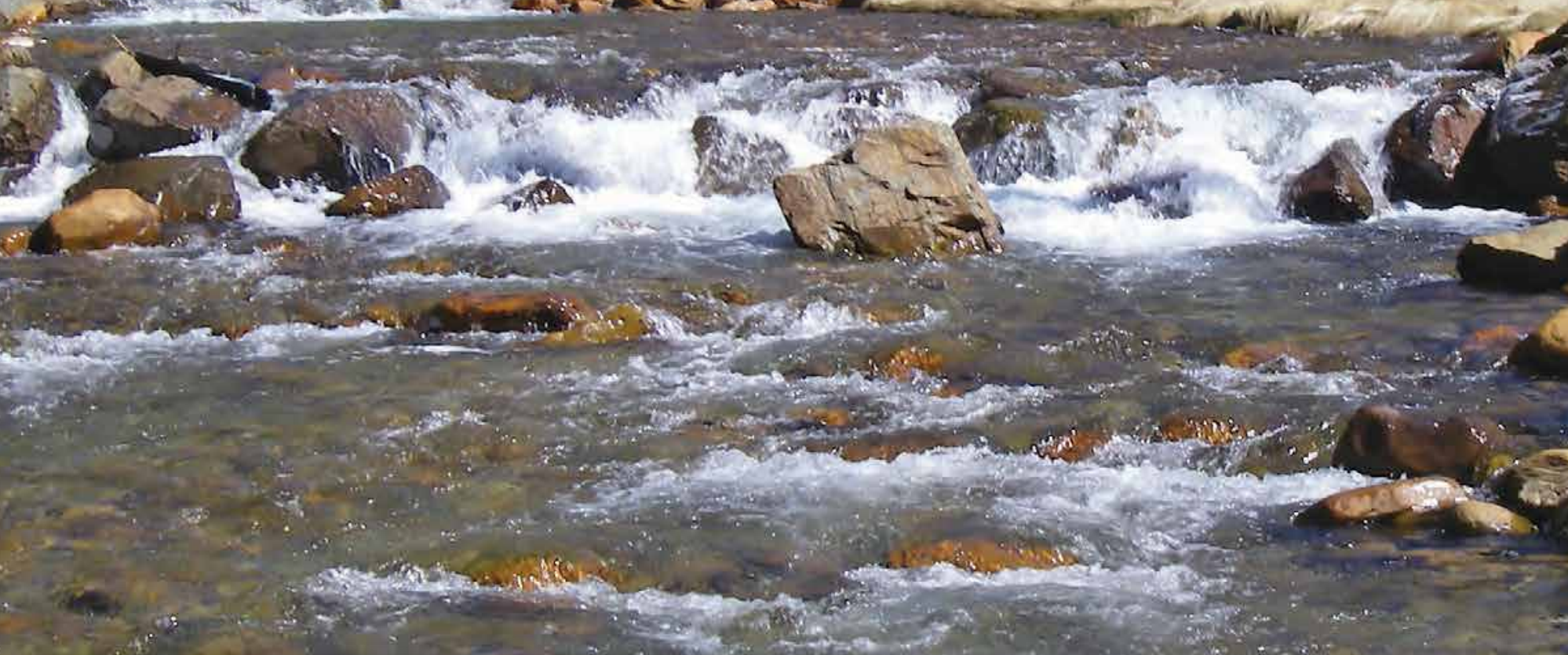

Scientific Investigations Report 2014-5204

U.S. Department of the Interion

U.S. Geological Survey: 
Front Cover: Canyon Creek near its confluence with the South Fork Coeur d'Alene River near Wallace, Idaho. Photograph taken by Gregory M. Clark, U.S. Geological Survey, April 17, 2013.

Back Cover: Collecting a water sample during spring runoff from the North Fork Coeur d'Alene River near Enaville, Idaho. Photograph taken by Gregory M. Clark, U.S. Geological Survey, May 19, 2008. 


\section{Sources, Transport, and Trends for Selected Trace Metals and Nutrients in the Coeur d'Alene and Spokane River Basins, Northern Idaho, 1990-2013}

By Gregory M. Clark and Christopher A. Mebane

Prepared in cooperation with the U.S. Environmental Protection Agency

Scientific Investigations Report 2014-5204 


\title{
U.S. Department of the Interior SALLY JEWELL, Secretary
}

\section{U.S. Geological Survey \\ Suzette M. Kimball, Acting Director}

\author{
U.S. Geological Survey, Reston, Virginia: 2014
}

For more information on the USGS - the Federal source for science about the Earth, its natural and living resources, natural hazards, and the environment, visit http://www.usgs.gov or call 1-888-ASK-USGS.

For an overview of USGS information products, including maps, imagery, and publications, visit http://www.usgs.gov/pubprod

To order this and other USGS information products, visit http://store.usgs.gov

Any use of trade, firm, or product names is for descriptive purposes only and does not imply endorsement by the U.S. Government.

Although this information product, for the most part, is in the public domain, it also may contain copyrighted materials as noted in the text. Permission to reproduce copyrighted items must be secured from the copyright owner.

Suggested citation:

Clark, G.M., and Mebane, C.A., 2014, Sources, transport, and trends for selected trace metals and nutrients in the Coeur d'Alene and Spokane River Basins, northern Idaho, 1990-2013: U.S. Geological Survey Scientific Investigations Report 2014-5204, 62 p., http://dx.doi.org/10.3133/sir20145204.

ISSN 2328-0328 (online) 


\section{Contents}

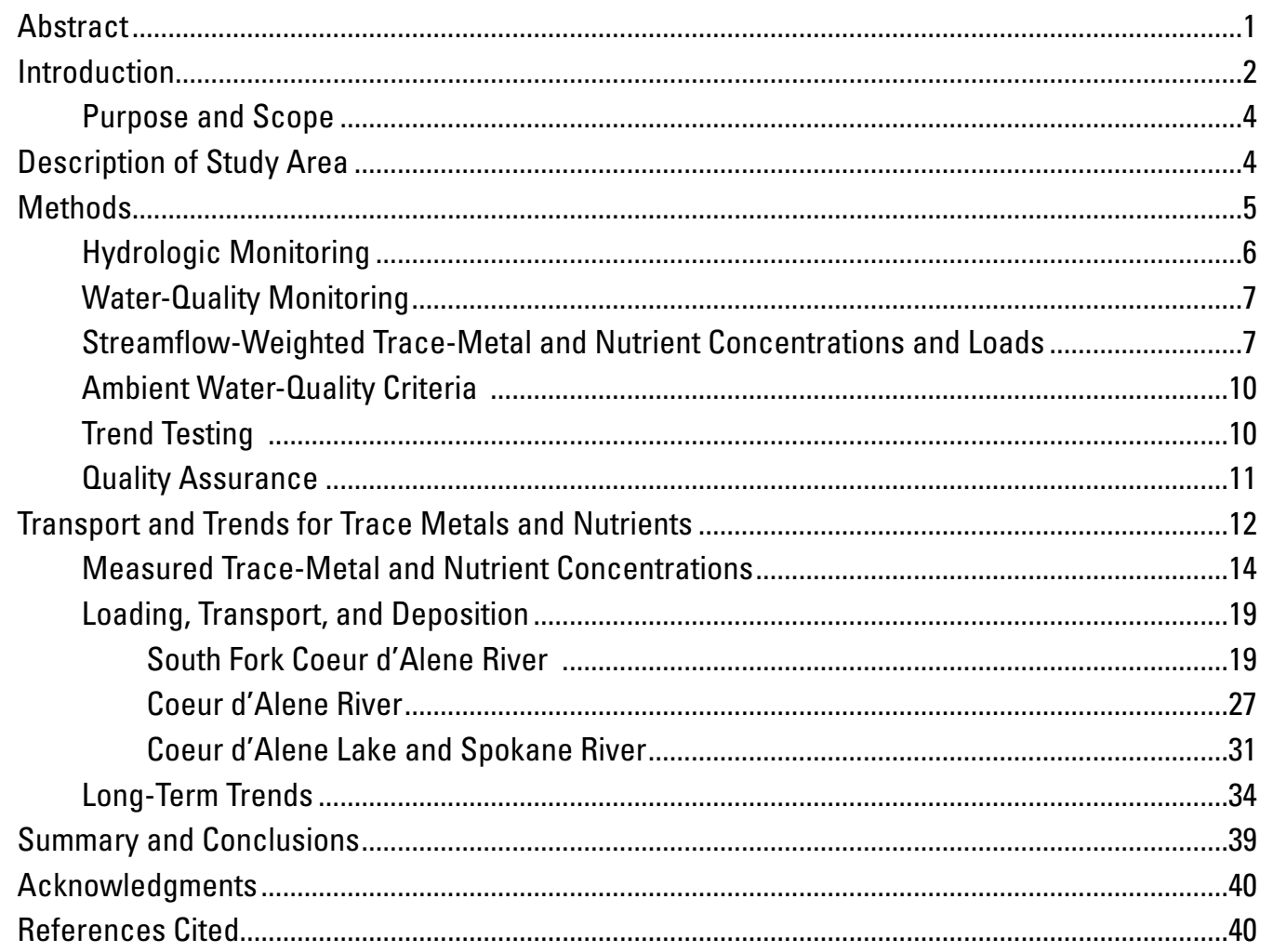




\section{Figures}

1. Map showing study area and sampling sites in the Coeur d'Alene and Spokane River Basins, northern Idaho

2. Hydrographs and water-quality samples collected at selected streamflow-gaging and water-quality sampling sites in the Coeur d'Alene and Spokane River Basins, northern Idaho, water years 2009-13.

3. Graph showing relation of total cadmium, zinc, and lead concentrations to variations in streamflow in the South Fork Coeur d'Alene River near Pinehurst, Idaho, water years 2009-13

4. Hydrographs showing daily mean streamflow at streamflow-gaging and water-quality sampling sites at South Fork Coeur d'Alene River near Pinehurst, Coeur d'Alene River near Cataldo, and Spokane River near Post Falls, Idaho, water years 2009-13, compared with the 25-year historical mean for water years 1989-2013

5. Boxplots showing dissolved and total cadmium, lead, and zinc concentrations in water samples collected at streamflow-gaging and water-quality sampling sites in the Coeur d'Alene and Spokane River Basins, northern Idaho, water years 2009-13

6. Boxplots showing Chronic Ambient Water Quality Criteria (AWOC) ratios for dissolved zinc and cadmium in water samples collected at streamflow-gaging and water-quality sampling sites in the Coeur d'Alene and Spokane River Basins, northern Idaho, water years 2009-13.

7. Boxplots showing total phosphorus and nitrogen concentrations in water samples collected at streamflow-gaging and water-quality sampling sites in the Coeur d'Alene and Spokane River Basins, northern Idaho, water years 2009-13

8. Diagrams showing mean annual streamflow, total cadmium loads, total lead loads, and total zinc loads at streamflow-gaging and water-quality sampling sites in the Coeur d'Alene and Spokane River Basins, northern Idaho, water years 2009-13

9. Diagrams showing mean annual total phosphorus and nitrogen loads at streamflow-gaging and water-quality sampling sites in the Coeur d'Alene and Spokane River Basins, northern Idaho, water years 2009-13.

10. Graphs showing relation of dissolved and total cadmium and zinc in the Coeur d'Alene River near Harrison, Idaho, water years 2009-13.

11. Graphs showing concentrations of total cadmium, lead, and zinc, and streamflow, in the Coeur d'Alene River near Harrison, Idaho, water years 2009-13.

12. Graphs showing concentrations of total cadmium, lead, and zinc in selected samples collected from the Coeur d'Alene River near Harrison, Idaho, water years 2011-13.

13. Graphs showing historical trends in total zinc concentrations at selected streamflow-gaging and water-quality sampling sites in the Coeur d'Alene and Spokane River Basins, northern Idaho, water years 1990-2013 and 2003-13.

14. Graphs showing historical trends in Ambient Water Quality Criteria ratios for cadmium and zinc at selected streamflow-gaging and water-quality sampling sites, Coeur d'Alene and Spokane River Basins, northern Idaho, water years 1990-2013 and 2003-13. 


\section{Tables}

1 Streamflow-gaging and water-quality sampling sites in the Coeur d'Alene and Spokane River Basins, northern Idaho, water years 2009-13...

2 Variation of chronic Ambient Water Quality Criteria for cadmium and zinc based on a range of hardness concentrations in the South Fork Coeur d'Alene River Basin and other parts of the Coeur d'Alene and Spokane River Basins, northern Idaho...

3 Results from field blanks and split replicate quality-control samples collected in the Coeur d'Alene and Spokane River Basins, northern Idaho, water years 2009-13

4 Estimated mean streamflow and mean streamflow-weighted concentrations and chronic Ambient Water Quality Criteria ratios for selected constituents at streamflow-gaging and water-quality sampling sites in the Coeur d'Alene and Spokane River Basins, northern Idaho, water years 2009-13

5 Annual loads of total phosphorus and total nitrogen and 95-percent confidence intervals for streamflow-gaging and water-quality sampling sites in the Coeur d'Alene and Spokane River Basins, northern Idaho, water years 2009-13

6 Results from Seasonal Kendall trend tests on concentrations of total cadmium, lead, and zinc, and chronic Ambient Water Quality Criteria ratios for dissolved cadmium and zinc at selected streamflow-gaging and water-quality sampling sites in the Coeur d'Alene and Spokane River Basins, northern Idaho, water years 1990-2013.

7. Regression coefficients, and coefficients of determination $\left(R^{2}\right)$ for models used to estimate streamflow-weighted concentrations and loads of selected trace metals and nutrients at streamflow-gaging and water-quality sampling sites in the Coeur d'Alene and Spokane River Basins, northern Idaho

8 Annual loads of dissolved and total cadmium, lead, and zinc and 95-percent confidence intervals for streamflow-gaging and water-quality sampling sites in the Coeur d'Alene and Spokane River Basins, northern Idaho, water years 2009-13 


\section{Conversion Factors, Datums, and Abbreviations and Acronyms}

\section{Conversion Factors}

Inch/Pound to SI

\begin{tabular}{|c|c|c|}
\hline Multiply & By & To obtain \\
\hline \multicolumn{3}{|c|}{ Length } \\
\hline inch (in.) & 2.54 & centimeter $(\mathrm{cm})$ \\
\hline foot $(\mathrm{ft})$ & 0.3048 & meter $(\mathrm{m})$ \\
\hline mile (mi) & 1.609 & kilometer (km) \\
\hline \multicolumn{3}{|c|}{ Area } \\
\hline acre & 4,047 & square meter $\left(\mathrm{m}^{2}\right)$ \\
\hline acre & 0.004047 & square kilometer $\left(\mathrm{km}^{2}\right)$ \\
\hline square mile $\left(\mathrm{mi}^{2}\right)$ & 2.590 & square kilometer $\left(\mathrm{km}^{2}\right)$ \\
\hline \multicolumn{3}{|c|}{ Volume } \\
\hline acre-foot (acre-ft) & 1,233 & cubic meter $\left(\mathrm{m}^{3}\right)$ \\
\hline \multicolumn{3}{|c|}{ Flow rate } \\
\hline cubic foot per second $\left(\mathrm{ft}^{3} / \mathrm{s}\right)$ & 0.02832 & cubic meter per second $\left(\mathrm{m}^{3} / \mathrm{s}\right)$ \\
\hline \multicolumn{3}{|c|}{ Mass } \\
\hline pound per day (lb/d) & 0.4536 & kilogram per day $(\mathrm{kg} / \mathrm{d})$ \\
\hline ton, short $(2,000 \mathrm{lb})$ & 0.9072 & megagram $(\mathrm{Mg})$ \\
\hline ton per year (ton/yr) & 0.9072 & metric ton per year \\
\hline \multicolumn{3}{|l|}{ SI to Inch/Pound } \\
\hline Multiply & By & To obtain \\
\hline \multicolumn{3}{|c|}{ Length } \\
\hline micrometer $(\mu \mathrm{m})$ & $3.9370 \times 10^{-5}$ & inch (in.) \\
\hline milliliter (mL) & 0.033814 & ounce, fluid (fl oz) \\
\hline
\end{tabular}

Temperature in degrees Fahrenheit $\left({ }^{\circ} \mathrm{F}\right)$ may be converted to degrees Celsius $\left({ }^{\circ} \mathrm{C}\right)$ as follows:

$$
{ }^{\circ} \mathrm{C}=\left({ }^{\circ} \mathrm{F}-32\right) / 1.8
$$

Concentrations of chemical constituents in water are given either in milligrams per liter (mg/L) or micrograms per liter $(\mu \mathrm{g} / \mathrm{L})$. 


\section{Conversion Factors, Datums, and Abbreviations and Acronyms-Continued}

\section{Datums}

Vertical coordinate information is referenced to the North American Vertical Datum of 1988 (NAVD 88).

Horizontal coordinate information is referenced to the North American Datum of 1983 (NAD 83).

Elevation, as used in this report, refers to distance above the vertical datum.

\section{Abbreviations and Acronyms}

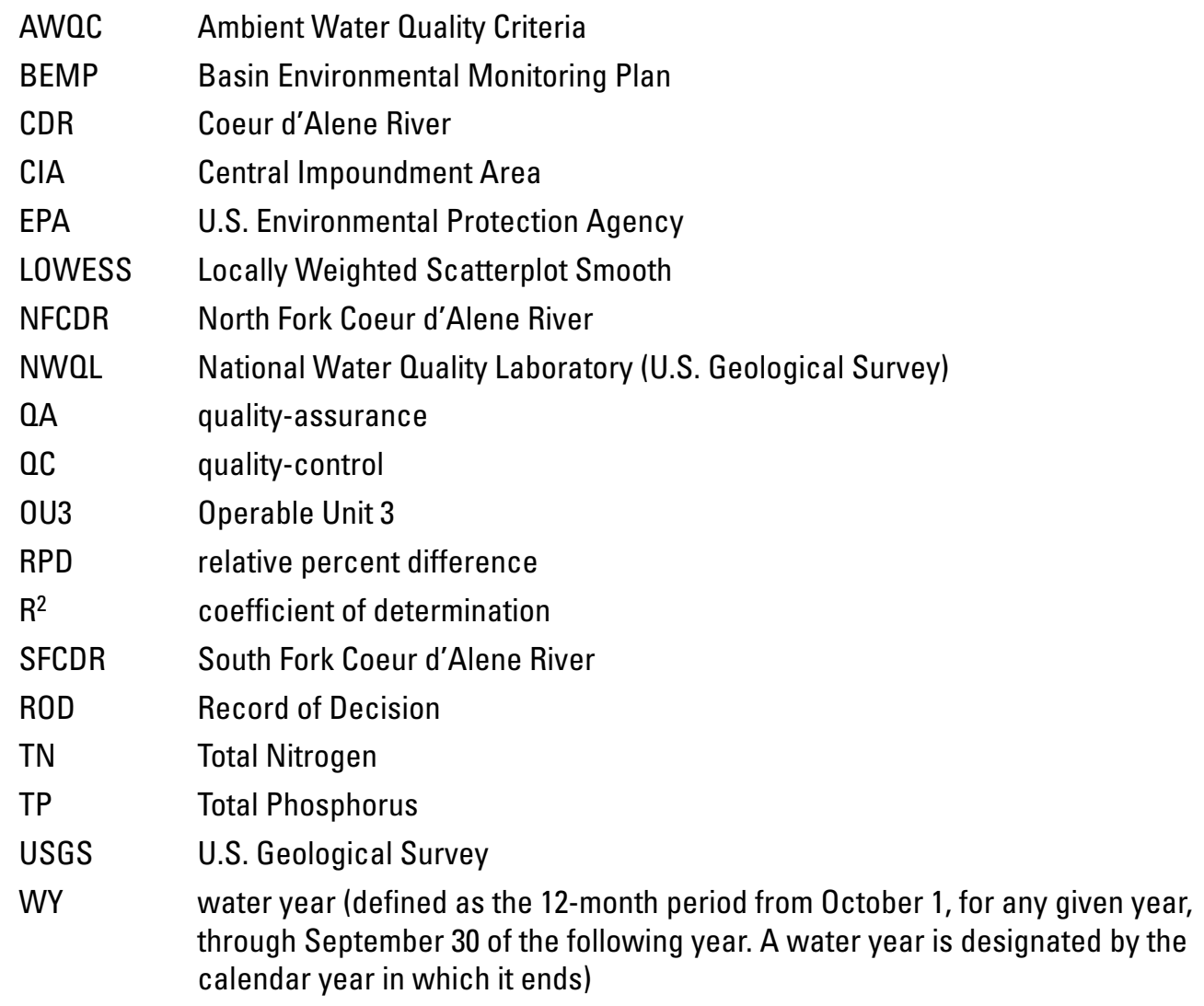





\title{
Sources, Transport, and Trends for Selected Trace Metals and Nutrients in the Coeur d'Alene and Spokane River Basins, Northern Idaho, 1990-2013
}

\author{
By Gregory M. Clark and Christopher A. Mebane
}

\section{Abstract}

Data collected at 18 streamflow-gaging and water-quality sampling sites in the Coeur d'Alene and Spokane River Basins of northern Idaho were used to estimate mean streamflow-weighted concentrations and annual loads of total and dissolved cadmium, lead, and zinc, and total phosphorus (TP) and nitrogen (TN) for water years (WYs) 2009-13. Chronic Ambient Water Quality Criteria (AWQC) and AWQC ratios also were calculated to evaluate Idaho aquatic life criteria for chronic exposure to cadmium and zinc in streams. At four sites with a longer period of record, a Seasonal Kendall trend test was used to assess historical trends in the concentrations of total cadmium, lead, and zinc, and chronic AWQC ratios for cadmium and zinc during WYs 1990-2013.

Concentrations of dissolved and total cadmium, lead, and zinc varied widely both at and among sites. At most sites, dissolved cadmium and zinc constituted most of the total concentrations; dissolved lead generally constituted less than 10 percent of the total lead concentration. Trace metal concentrations increased by 2 to 4 orders of magnitude along the South Fork Coeur d'Alene River (SFCDR) from near Mullan (site 2) downstream to near Pinehurst (site 13). The mean streamflow-weighted concentrations of total cadmium, lead, and zinc in the SFCDR near Pinehurst for WYs 2009-13 were 3.71, 61.4, and 514 micrograms per liter $(\mu \mathrm{g} / \mathrm{L})$, respectively. In the Coeur d'Alene River (CDR) near Harrison (site 15), downstream of the confluence of the metal-enriched SFCDR and the relatively dilute North Fork Coeur d'Alene River (NFCDR), the mean streamflow-weighted concentrations of total cadmium, lead, and zinc were $1.58,125$, and $236 \mu \mathrm{g} / \mathrm{L}$, respectively. Trace-metal concentrations were smaller in the Spokane River than in the CDR because of dilution and retention of trace metals in Coeur d'Alene Lake. The mean streamflow-weighted concentrations of total cadmium, lead, and zinc in the Spokane River near Post Falls (site 18) were 0.231, 2.91, and $48.9 \mu \mathrm{g} / \mathrm{L}$, respectively.
AWQC ratios indicate that cadmium and zinc concentrations met the chronic criteria (ratio of less than 1.0) for the protection of aquatic life at only three sites: the NFCDR at Enaville (site 1), the upper SFCDR near Mullan (site 2), and the St. Joe River near St. Maries (site 16). Cadmium and zinc concentrations at sites on the Spokane River (sites 17 and 18) generally were close to the chronic AWQC values. The sites with the largest chronic AWQC ratios in the Coeur d'Alene and Spokane River Basins for both cadmium and zinc were in the Canyon and Ninemile Creek basins (sites 3-6).

Concentrations of TP and TN generally were low along the SFCDR downstream to Kellogg. From the SFCDR near Kellogg (site 9) downstream to the SFCDR above Pine Creek (site 11), the mean streamflow-weighted concentration of the nutrients TP and TN increased by 0.036 milligram per liter (mg/L) (200 percent) and $0.124 \mathrm{mg} / \mathrm{L}$ (78 percent), respectively. The increases in nutrient concentrations along the SFCDR likely are in response to discharge from wastewater-treatment facilities. Mean streamflow-weighted concentrations for TP and $\mathrm{TN}(0.054$ and $0.284 \mathrm{mg} / \mathrm{L}$, respectively) were the highest in the sampling network in the SFCDR above Pine Creek (site 11).

LOADEST modeling was used to relate mass transport, or load, of trace metals and nutrients to variations in streamflow and time. Results indicate that most of the cadmium and zinc load in the Coeur d'Alene and Spokane Rivers is derived from the SFCDR, and that most of the lead load is derived from the Coeur d'Alene River downstream of the confluence of the NFCDR and SFCDR. Major tributary sources of trace metals to the SFCDR are Canyon Creek and Ninemile Creek. Combined, these two tributaries contributed estimated mean loads of about 0.575 ton per year (ton/yr) of total cadmium, 5.29 ton/yr of total lead, and 90.9 ton/yr of total zinc to the SFCDR during WYs 2009-13. Groundwater discharge and tributaries near the Central Impoundment Area between SFCDR near Kellogg (site 9) and SFCDR near Smelterville (site 10) were other primary sources of cadmium and zinc. Combined, these sources contributed an estimated 1.39 ton/yr of total cadmium and 143 ton/yr of total zinc to the SFCDR during WYs 2009-13. 
Erosion and transport of sediment-bound lead contained in the CDR flood plain and on the river bottom between Cataldo (site 14) and Harrison (site 15) were the primary source of lead. During WYs 2009-13, the mean load of trace metals delivered to Coeur d'Alene Lake included about $4.66 \mathrm{ton} / \mathrm{yr}$ of total cadmium, $398 \mathrm{ton} / \mathrm{yr}$ of total lead, and 698 ton/yr of total zinc. About 99 percent of the trace-metal load to the lake was from the CDR as measured near site 15 at Harrison. During WYs 2009-13, about 1.48 ton/yr of cadmium, 18 ton/yr of lead, and 350 ton/yr of zinc were transported from Coeur d'Alene Lake into the Spokane River as measured at the lake outlet (site 17).

During WYs 2009-13, the loads of TP and TN delivered from the Coeur d'Alene and St. Joe Rivers to Coeur d'Alene Lake were about equivalent. On average, the CDR transported about 93.6 tons of TP and 369 tons of TN, and the St. Joe River transported about 92.9 tons of TP and 360 tons of TN to the lake during 2009-13. About 52.9 ton/yr of TP and 628 ton/yr of TN were transported from Coeur d'Alene Lake to the Spokane River during WYs 2009-13.

Results from Seasonal Kendall trend tests indicate statistically significant downward temporal trends during WYs 1990-2013 for total cadmium, lead, zinc, and chronic AWQC ratios of cadmium and zinc in the SFCDR at Elizabeth Park (site 8) and near Pinehurst (site 13), and in the CDR near Harrison (site 15). Statistically significant downward temporal trends for total lead, zinc, and the chronic AWQC ratio of zinc also occurred in the Spokane River near Post Falls (site 18) during WYs 1991-2013. Seasonal Kendall trend tests for WYs 2003-13 indicated statistically significant downward trends for total cadmium, zinc, and chronic AWQC ratios of cadmium and zinc in the SFCDR at Elizabeth Park (site 8). The Spokane River near Post Falls (site 18) had a statistically significant downward trend for total zinc during WYs 2003-13, and a significant upward trend for the chronic AWQC ratio of cadmium. No significant trends were found in trace-metal concentrations or chronic AWQC ratios in the SFCDR near Pinehurst (site 13) and the CDR near Harrison (site 15) during WYs 2003-13.

Results from this study indicate that remedial activities conducted since the 1990s have been successful in reducing the concentrations and loads of trace metals in streams and rivers in the Coeur d'Alene and Spokane River Basins. Soils, sediment, surface water, and groundwater in areas of the Coeur d'Alene and Spokane River Basins are contaminated, and the hydrological relations between these media are complex and difficult to characterize. Trace metals have variable source areas, are transported differently depending on hydrologic conditions, and behave differently in response to remedial activities in upstream basins. Based on these findings, no single remedial action would be completely effective in reducing all trace metals to nontoxic concentrations throughout the Coeur d'Alene and Spokane River Basins. Instead, unique cleanup activities targeted at specific media and specific source areas may be necessary to achieve long-term water-quality goals.

\section{Introduction}

Mining and ore-processing activities since the late 1800s in the Coeur d'Alene mining district in northern Idaho have altered the water quality, aquatic biological, and hydrologic conditions in the Spokane and Coeur d'Alene River Basins (fig. 1). From 1883 through 1987, more than 130 million tons of lead, zinc, and silver-sulfide ores were mined from the Coeur d'Alene Mining district (Long, 1998), primarily in the South Fork Coeur d'Alene River (SFCDR) Basin. Historical ore-processing activities in the SFCDR Basin resulted in large quantities of metal-rich tailings that were placed directly in and along streams (Long, 1998) and subsequently were transported downstream. Although direct dumping of tailings into streams ceased in 1968, metal-enriched streambed sediments and abandoned tailings have produced, and continue to produce, trace-metal-contaminated water (Woods, 2001, Clark, 2003, Donato, 2006) and extensive deposits of trace-metal-contaminated sediment throughout the SFCDR Basin, the channel and flood plain of the main-stem Coeur d'Alene River (CDR) (Bookstrom and others, 2001; Box and others, 2005), and the lakebed of Coeur d'Alene Lake (Horowitz and others, 1995; Woods and Beckwith, 1997; Wood and Beckwith, 2008). Annual snowmelt runoff, frequent rain-on-snow events, and occasional floods continue to transport and redistribute trace-metal-contaminated sediments throughout the CDR Basin and into the Spokane River of eastern Washington (Maret and Skinner, 2000; Grosbois and others, 2001; Box and others, 2005). The estimated total mass and extent of affected materials (primarily sediments) exceeds 100 million tons dispersed over thousands of acres (U.S. Environmental Protection Agency, 2001). Additionally, groundwater adjacent to the SFCDR and some of its tributaries has become contaminated with trace metals (Barton, 2002).

In 1998, the U.S. Environmental Protection Agency (EPA) began a Remedial Investigation/ Feasibility Study to assess mining-associated contamination throughout the broader CDR Basin outside the original 21- $\mathrm{mi}^{2}$ Superfund site surrounding the defunct Bunker Hill Mine and ore-processing complex in Kellogg, Idaho (U.S. Environmental Protection Agency, 2001). Referred to as "Operable Unit 3 (OU3)," it encompasses the SFCDR and its tributaries, the lower CDR and associated lateral lakes, Coeur d'Alene Lake, and depositional areas of the Spokane River. In 2002, the EPA issued a Record of Decision (ROD) for OU3 describing specific cleanup work to be done over a 30-year period at a cost of about $\$ 360$ million dollars (U.S. Environmental Protection Agency, 2002a). As part of the 2002 ROD, a Basin Environmental Monitoring Plan (BEMP) was established in 2004 to monitor the surface-water, soil/sediment, and biological resources in OU3 (U.S. Environmental Protection Agency, 2004). The purpose of the BEMP is to provide data in support of cleanup efforts, and to make adjustments and modifications to optimize remedial activities in the basin. 


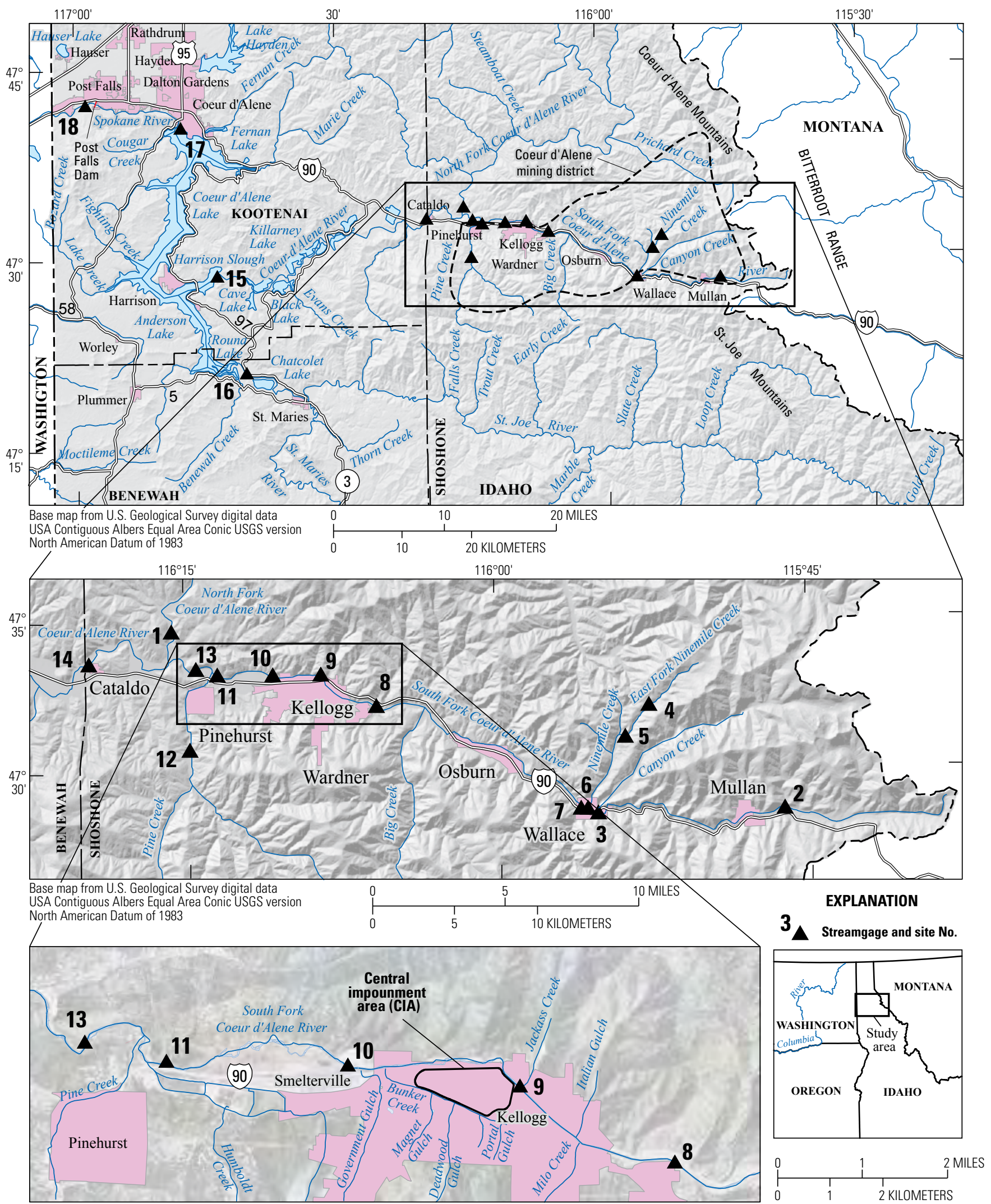

Base map from National Agricultural Imagery Program (NAIP; aerial imagery); National Hydrology Dataset Plus (NHDPlus; hydrography)

Figure 1. Study area and sampling sites in the Coeur d'Alene and Spokane River Basins, northern Idaho. 
Considerable efforts have been made to mitigate the adverse environmental effects of past mining in the basin, primarily along the SFCDR and its tributaries. The EPA, State of Idaho, other Federal agencies, and the mining industry have conducted site-specific sediment-removal, reclamation, and stream-channel rehabilitation projects, and have evaluated environmental contamination and remediation options in mining-affected areas. In addition to cleanup work in residential areas, remedial work has been completed at numerous mine and mill sites along the SFCDR as well as at recreational sites along the Coeur d'Alene and Spokane Rivers. Remedial actions have included grading and capping of contaminated materials, installing site access barriers and controls, and stabilizing eroded riverbanks (U.S. Environmental Protection Agency, 2010). The scale and complexity of contamination issues in the study area are such that the area has been considered a "mining megasite," and it was not possible for the EPA to specify a "final" remedy following remedial investigations and feasibility studies. Instead, an adaptive management approach is being taken. An adaptive approach to site restoration involves a cyclical process of study, remedial design, implementation, performance monitoring, and redesign that views the restoration process itself as a management experiment (National Academy of Sciences, 2005; Gustavson and others, 2007). This report describes one aspect of the performance monitoring intended to reflect whether interim cleanup steps have resulted in measurable improvements in water quality. The work was accomplished in cooperation with the EPA.

\section{Purpose and Scope}

This report documents methods used and results of statistical analyses of data collected as part of the BEMP. Water-quality and streamflow data from 18 surface-water sites in the OU3 study area were used to determine streamflow-weighted concentrations and mass transport of selected trace metals and nutrients during water years (WYs) 2009-13. Historical data also were used to evaluate long-term trends in concentrations of cadmium, lead, and zinc, and chronic Ambient Water Quality Criteria (AWQC) for cadmium and zinc at four sites during WYs 1990-2013. Findings from this assessment will provide an improved understanding of the processes affecting the variability in trace-metal concentrations and their transport throughout the Coeur d'Alene and Spokane River Basins. The nutrients nitrogen and phosphorus are included in this report because of their role in enrichment and eutrophication of Coeur d'Alene Lake, which potentially could result in mobilization of trace metals stored in lakebed sediments. The data and findings from this report can provide a baseline with which to evaluate the effectiveness of future remedial activities in the Coeur d'Alene River Basin.

\section{Description of Study Area}

The 3,830 $\mathrm{mi}^{2}$ study area is in Benewah and Shoshone Counties in northern Idaho (fig. 1). Elevations range from about $2,000 \mathrm{ft}$ at the Idaho-Washington border to about $6,850 \mathrm{ft}$ at the Idaho-Montana border. Coeur d'Alene Lake, at the western edge of the study area, has a surface elevation of about $2,128 \mathrm{ft}$ at full pool. The lake lies in a naturally dammed river valley with a surface area of about $50 \mathrm{mi}^{2}$, a volume of about 811,000 acre-ft, a length of about $25 \mathrm{mi}$, and a width of 1-2 mi along most of its length (National Academy of Sciences, 2005). The volume and outflow of the lake are controlled by Post Falls Dam, which was constructed in 1906 and raised the lake level by $8 \mathrm{ft}$ to provide hydroelectric power, flood control, and irrigation supply (Woods and Beckwith, 1997). About 90 percent of the surface-water inflow to the lake is delivered by the Coeur d'Alene and the St. Joe Rivers, which drain the Coeur d'Alene and St. Joe Mountains in the Bitterroot Range (fig. 1).

Temperatures and precipitation in the Coeur d'Alene and Spokane River Basins vary substantially, both from year to year and from high to low elevations. The study area receives some of the largest amounts of precipitation in Idaho, with about 70 percent of the annual precipitation falling as snow during October-April (Woods and Beckwith, 1997). The areal distribution of precipitation is influenced by the topography of the basin. For example, the climatological station at Coeur d'Alene, Idaho (elevation 2,159 ft) records a mean annual precipitation of 25.4 in., whereas the station at Wallace, Idaho (elevation 2,940 ft) records a mean annual precipitation of $38.2 \mathrm{in}$. Ambient temperature varies throughout the study area, depending on elevation: at Coeur d'Alene, the mean annual temperature is $48^{\circ} \mathrm{F}$, whereas, at Wallace, the mean annual temperature is $44^{\circ} \mathrm{F}$. Although winter temperatures at Coeur d'Alene Lake often are below freezing, the lake typically does not freeze except in its shallow southern end. Normally, the winter snowpack melts slowly in late spring and early summer. However, warm winter Pacific storms in the study area can bring a sudden onset of above-freezing temperatures and possible heavy rains on top of preexisting snowpacks. These "rain-on-snow" events can result in rapid snowmelt and produce an abrupt increase over the usual low winter base flows in the river (Box and others, 2005). The basin also is subject to intense local storms that are characteristic of mountainous areas. These summer thunderstorms are of short duration, but they can cause significant rill erosion, mass wasting (downslope movement of rock and soil under the influence of gravity), and transport of colluvium and mine waste from steep slopes as turbid water or debris flows.

The St. Joe River (drainage area of 1,745 $\mathrm{mi}^{2}$ ) discharges into the southern end of Coeur d'Alene Lake (fig. 1). The St. Joe River is joined by the St. Maries River at the town of St. Maries. Recreation and logging are the dominant land uses in the St. Joe River Basin. Although the St. Joe River 
contributes nitrogen and phosphorus to Coeur d'Alene Lake (Idaho Department of Environmental Quality and Coeur d'Alene Tribe, 2009), little mining activity has occurred in the St. Joe River Basin; therefore, the basin contributes only small quantities of trace metals compared to the Coeur d'Alene River.

The Coeur d'Alene River Basin consists of the South Fork (drainage area of $299 \mathrm{mi}^{2}$ ) and the North Fork (drainage area of $895 \mathrm{mi}^{2}$ ), which merge 4 mi upstream of the town of Cataldo (fig. 1). Downstream of this confluence is the main stem of the CDR, which flows $29 \mathrm{mi}$ to Coeur d'Alene Lake. The Coeur d'Alene River Basin contains three distinct topographical regions differentiated on the basis of stream gradient and floodplain characteristics. The first region includes the upper reach of the SFCDR from the Bitterroot Mountains to the town of Wallace, the upper reach of the North Fork Coeur d'Alene River (NFCDR), and all their tributaries. This upper region is characterized by steep stream gradients and a limited floodplain. The reach of the SFCDR from Wallace to Cataldo is the second region, and is characterized by a wide flood plain bordered by steep valley walls and a moderate river gradient. The third region is considered the lower Coeur d'Alene River Basin, encompassing the main stem of the CDR, which runs from Cataldo downstream to Harrison. In this reach, the river system actually is deltaic and the channel often is in backwater from Coeur d'Alene Lake. The river channel in the CDR follows a meandering pattern and, for most of the year, has an imperceptible gradient when Coeur d'Alene Lake is at full pool. The flood plain in this area is broad and contains multiple lateral lakes and wetlands.

The Spokane River drains Coeur d'Alene Lake at its north end. The Spokane River flows westward toward the city of Spokane and eventually joins the Columbia River about $110 \mathrm{mi}$ downstream of the lake. An important feature to the north and west of the lake outlet is the Spokane Valley-Rathdrum Prairie aquifer, a $410 \mathrm{mi}^{2}$ valley-fill aquifer created during the Pleistocene by repeated outburst floods from glacial Lake Missoula. The aquifer is the sole source of water for most people in Spokane County, Washington, and Kootenai County, Idaho, supplying drinking water to more than 500,000 people (Caldwell and Bowers, 2003). In the study area, the aquifer is recharged by seepage from the Spokane River between the Coeur d'Alene Lake outlet and the Idaho-Washington state line. Maupin and Weakland (2009) estimated that during WYs 2000-2005, the Spokane River lost an average of about $230 \mathrm{ft}^{3} / \mathrm{s}$ to the underlying aquifer between the streamgage at the Coeur d'Alene Lake outlet (site 17) and downstream at Post Falls (site 18) (fig. 1).

The magnitude and timing of streamflow in the Spokane and Coeur d'Alene Basins generally is determined by the amount of water derived from the winter snowpack. As such, rivers and streams in the Coeur d'Alene and Spokane Rivers typically reach peak flows in April and May in association with spring snowmelt runoff. However, high streamflows also can occur at low-elevation areas of the Coeur d'Alene River Basin in autumn and winter in response to rain-on-snow events that can cause flooding and substantial transport of sediment and sediment-bound trace metals. Generally, when precipitation and winter snowpack are less than average, streamflow from runoff is lower than normal, and transport of sediment and sediment-bound trace metals is less than average. In contrast, when precipitation, winter snowpack, and runoff are greater than average, sediment and trace metal transport may be greater than normal. Generally, streamflows decrease rapidly over the summer following the loss of the snowpack, with the lowest streamflows typically occurring in September and October.

\section{Methods}

The surface-water BEMP was implemented in 2004 with a network of 15 sites: 7 sentinel and 8 benchmark sites. Sentinel sites were selected to provide information relative to basin-wide conditions and to evaluate mass transport of trace metals. Sentinel sites were sampled eight times per year based on hydrographic events rather than on a fixed time-interval basis. These events were early autumn base flow, initial flush following autumn base flow, winter base flow, early spring rain-on-snow, spring snowmelt runoff, and the summer hydrograph recession. Benchmark sites were selected to provide long-term trend information and to evaluate year-to-year variability in concentrations of dissolved metals. Benchmark sites were sampled only every fifth year, augmented with an annual low-flow sample collected each year in autumn for dissolved trace metals. Every fifth year, starting in WY 2008, benchmark sites were sampled eight times per year during the same hydrographic conditions as sentinel sites.

Following its inception in 2004, the surface-water BEMP has changed significantly. Three new sentinel sites were added to the network, resulting in a total of 18 streamflow-gaging (streamgage) and water-quality sampling sites (table 1). The sites added were on the SFCDR at Kellogg (site 9) in 2006, the SFCDR above Pine Creek near Pinehurst (site 11) in 2008, and the SFCDR above Placer Creek near Wallace (site 7) in WY 2009. In WY 2010, the site on the St. Joe River was relocated about 2 mi upstream on the St. Joe River at Ramsdell near St. Maries (site 16) to record streamflow that is diverted from the river upstream of the original site and is returned to the lake downstream. The current St. Joe River site is upstream of the diversion and, thus, more accurately represents the total streamflow and mass of trace metals and nutrients entering the lake from the St. Joe River Basin. 
Table 1. Streamflow-gaging and water-quality sampling sites in the Coeur d'Alene and Spokane River Basins, northern Idaho, water years 2009-13.

[Locations of stations are shown in figure 1. Abbreviations; Q, streamflow; ADVM, acoustic Doppler velocity meter; USGS, U.S. Geological Survey]

\begin{tabular}{|c|c|c|c|c|}
\hline $\begin{array}{l}\text { Site } \\
\text { No. }\end{array}$ & Streamgage No. & Streamgage name & $\begin{array}{l}\text { Type of streamflow } \\
\text { record }\end{array}$ & $\begin{array}{c}\text { Number of water- } \\
\text { quality samples }\end{array}$ \\
\hline 1 & 12413000 & North Fork Coeur d'Alene River at Enaville, Idaho & Continuous, stage-Q & 23 \\
\hline 2 & 12413040 & $\begin{array}{l}\text { South Fork Coeur d'Alene River above Deadman } \\
\text { Gulch near Mullan, Idaho }\end{array}$ & Indexed & 7 \\
\hline 3 & 12413125 & Canyon Creek above mouth at Wallace, Idaho & Continuous, stage-Q & 23 \\
\hline 4 & 124131265 & $\begin{array}{l}\text { East Fork Ninemile Creek above Success Mine near } \\
\text { Blackcloud, Idaho }\end{array}$ & Indexed & 9 \\
\hline 5 & 12413127 & $\begin{array}{l}\text { East Fork Ninemile Creek above mouth near } \\
\text { Blackcloud, Idaho }\end{array}$ & Indexed & 9 \\
\hline 6 & 12413130 & Ninemile Creek above mouth at Wallace Idaho & Continuous, stage-Q & 24 \\
\hline 7 & 12413131 & $\begin{array}{l}\text { South Fork Coeur d'Alene River above Placer Creek } \\
\text { at Wallace, Idaho }\end{array}$ & Continuous, stage-Q & 15 \\
\hline 8 & 12413210 & $\begin{array}{l}\text { South Fork Coeur d'Alene River at Elizabeth Park } \\
\text { near Kellogg, Idaho }\end{array}$ & Continuous, stage-Q & 23 \\
\hline 9 & 12413250 & South Fork Coeur d'Alene River at Kellogg, Idaho & Indexed & 23 \\
\hline 10 & 12413300 & South Fork Coeur d'Alene River at Smelterville, Idaho & Indexed & 23 \\
\hline 11 & 12413355 & $\begin{array}{l}\text { South Fork Coeur d'Alene River above Pine Creek } \\
\text { near Pinehurst, Idaho }\end{array}$ & Continuous, stage-Q & 23 \\
\hline 12 & 12413445 & Pine Creek below Amy Gulch near Pinehurst Idaho & Continuous, stage-Q & 7 \\
\hline 13 & 12413470 & South Fork Coeur d'Alene River near Pinehurst, Idaho & Continuous, stage-Q & 23 \\
\hline 14 & 12413500 & Coeur d'Alene River near Cataldo, Idaho & Continuous, stage-Q & 15 \\
\hline 15 & 12413860 & Coeur d'Alene River near Harrison, Idaho & Continuous, ADVM & 30 \\
\hline 16 & 12415135 & St. Joe River at Ramsdell near St. Maries, Idaho ${ }^{1}$ & Continuous, ADVM & 30 \\
\hline 17 & 12417610 & $\begin{array}{l}\text { Spokane River near Coeur d'Alene Lake Outlet at } \\
\text { Coeur d'Alene, Idaho }\end{array}$ & Continuous, ADVM & 30 \\
\hline 18 & 12419000 & Spokane River near Post Falls, Idaho ${ }^{2}$ & Continuous, stage-Q & 17 \\
\hline
\end{tabular}

${ }^{1}$ Water-quality data from USGS station No. 12415140 (St. Joe River at Chatcholet, Idaho) were combined with this station for analysis.

${ }^{2}$ Water-quality data from USGS station No. 12419495 (Spokane River near Greenacres, Washington) were combined with this station for analysis.

In WY 2010, the distinction between sentinel and benchmark sites was eliminated. However, the frequency of sampling at the sites was reduced ranging from 2 times per year at 4 sites to 6 times per year at 3 sites; 11 sites were sampled 4 times per year. Because of these modifications to the sampling design and sampling strategy, the number of samples collected during WYs 2009-13 varied between sites, ranging from a minimum of 7 samples ( 2 sites) to a maximum of 30 samples (3 sites) (table 1$)$.

\section{Hydrologic Monitoring}

Streamflow at the 18 BEMP streamflow-gaging and water-quality sampling sites (fig. 1, table 1) was measured using standard U.S. Geological Survey (USGS) methods as described in Mueller and Wagner (2009) and Turnipseed and Sauer (2010). Continuous streamflow records were computed using methods described in Rantz and others (1982). At 10 of the 18 sites, streamflow was measured using a continuous record of water stage calibrated to periodic streamflow measurements. At three of the sites affected by fluctuating lake levels in Coeur d'Alene Lake (sites 15-17), an acoustic Doppler velocity meter was installed to compute streamflow using an index velocity method (Levesque and Oberg, 2012). Five sites (sites 2, 4, 5, 9, and 10) were not equipped with a continuous record of streamflow, and were correlated (indexed) using regression of measured instantaneous streamflow collected across a wide range of streamflow conditions at a nearby streamflow-gaging and water-quality sampling site with continuous record. The regression relation 
between the instantaneous measurements and the continuous record was used to generate a daily mean streamflow record for the non-gaged site for WYs 2009-13. For example, the instantaneous streamflow measurements on the SFCDR above Deadman Gulch near Mullan (site 2) were regressed with the continuous streamflow record on Canyon Creek above mouth at Wallace (site 3). The resultant regression equation $\left(\mathrm{R}^{2}=0.97\right)$ was used to estimate the daily mean streamflow for the SFCDR near Mullan (site 2) for WYs 2009-13.

\section{Water-Quality Monitoring}

Most of the water-quality data used in this report were collected during WYs 2009-13 at the 18 streamflow-gaging and water-quality sampling sites in the BEMP network (table 1). However, additional data (collected by the USGS during WYs 1990-2008 and available online at http:// waterdata.usgs.gov/nwis/) were used in the development of streamflow-concentration regression models, and to evaluate longer-term trends in the concentrations of cadmium, lead, and zinc and chronic AWQC in the SFCDR at Elizabeth Park (site 8), the SFCDR near Pinehurst (site 13), the CDR near Harrison (site 15), and the Spokane River near Post Falls (site 18). These historical data were collected and analyzed using USGS procedures and protocols similar to those used in this investigation, and have been used by Woods and Beckwith (1997), Clark (2003), and Donato (2006).

Although the number of samples collected at each site varied, the sampling approach at each site was to allocate samples over the full range of the station hydrograph in order to develop a robust relation between constituent concentration and streamflow. Hydrographs and sample timing during WYs 2009-13 for Pine Creek below Amy Gulch near Pinehurst (site 12), the SFCDR near Pinehurst (site 13), and the Spokane River near Post Falls (site 18) are shown in figure 2. The number of water-quality samples collected during WYs 2009-13 at each of the BEMP sites are listed in table 1.

Samples at all sites were collected using nonmetallic samplers and cross-sectional, depth-integrated sampling procedures (U.S. Geological Survey, various dates). Parameters collected in the field included $\mathrm{pH}$, water temperature, specific conductance, and dissolved oxygen. Samples for laboratory analyses were composited and subsampled using a polyethylene churn splitting device. Samples for whole-water recoverable (total) analyses of cadmium, lead, zinc, nitrogen, and phosphorus were withdrawn directly from the splitting device. Samples for dissolved (smaller than 0.45 -micrometer $[\mu \mathrm{m}]$ diameter) analyses of cadmium, lead, and zinc were withdrawn directly from the churn splitter and filtered through a pre-rinsed, $0.45-\mu \mathrm{m}$ pore size, disposable capsule filter. Constituent concentrations obtained from analysis of the $0.45-\mu \mathrm{m}$ filtrate are referred to as "dissolved" concentrations in this report. Samples for TP and TN were preserved with $1 \mathrm{~mL}$ of sulfuric acid and chilled. Samples to be analyzed for cadmium, lead, and zinc were preserved with $2 \mathrm{~mL}$ of Ultrex ${ }^{\circledR}$ nitric acid. Samples were shipped in plastic coolers to the USGS National Water Quality Laboratory (NWQL) in Denver, Colorado. Field blanks and split replicates equal to about 20 percent of the total number of samples were collected and submitted for quality-assurance purposes as described by the U.S. Geological Survey (various dates).

All the water-quality samples were analyzed at the NWQL using established analytical techniques. Concentrations of TP and TN were analyzed by colorimetric methods as described by Fishman (1993) and Patton and Kryskalla (2003). Cadmium, lead, and zinc concentrations were determined by atomic absorption spectrometry in conjunction with a graphite furnace and inductively coupled plasma-mass spectrometry (Fishman, 1993). Qualityassurance/quality-control procedures used at the NWQL are documented by Pritt and Raese (1995). All the data collected as part of this study are publicly available at http://waterdata. usgs.gov/nwis/.

\section{Streamflow-Weighted Trace-Metal and Nutrient Concentrations and Loads}

Trace-metal and nutrient concentrations in a stream vary in relation to streamflow. For example, in samples collected during WYs 2009-13 from the SFCDR near Pinehurst (site 13), concentrations of total cadmium and zinc generally decreased and concentrations of total lead generally increased with increasing streamflow (fig. 3). The relation between concentration and streamflow in the SFCDR near Pinehurst (site 13) typifies many of the mining-affected streams in the Spokane and Coeur d'Alene River Basins. Because of this variability, summary statistics, such as mean concentration, might include bias resulting from variation in the sampling frequency and the timing of sampling over the stream hydrograph. For this study, mean streamflow-weighted concentrations and loads were simulated using LOADEST, a FORTRAN program for estimating constituent loads in streams and rivers (Runkel and others, 2004). The LOADEST modeling program is based on a rating-curve method (Cohn and others, 1989, 1992; Crawford, 1991) that uses regression to estimate constituent load in relation to several predictor variables related to streamflow and time. This type of model has been used to estimate constituent concentrations for periods when sample data were not available (Gilroy and others, 1990), to estimate a basin flux of water-quality constituents (Goolsby and others, 1999), and to evaluate long-term trends in water-quality data (Smith and others, 1987). 

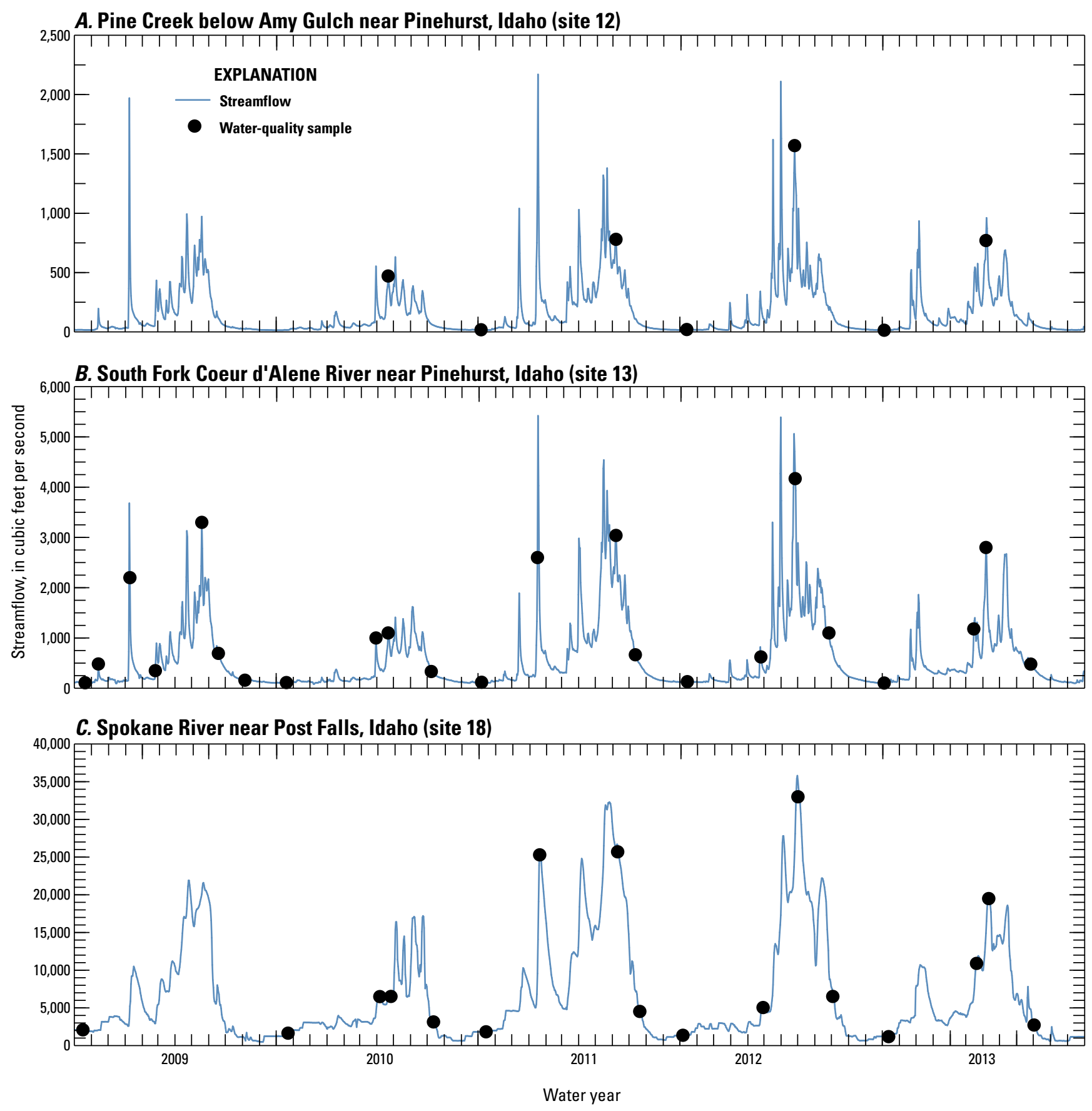

Figure 2. Hydrographs and water-quality samples collected at selected streamflow-gaging and water-quality sampling sites in the Coeur d'Alene and Spokane River Basins, northern Idaho, water years 2009-13. 


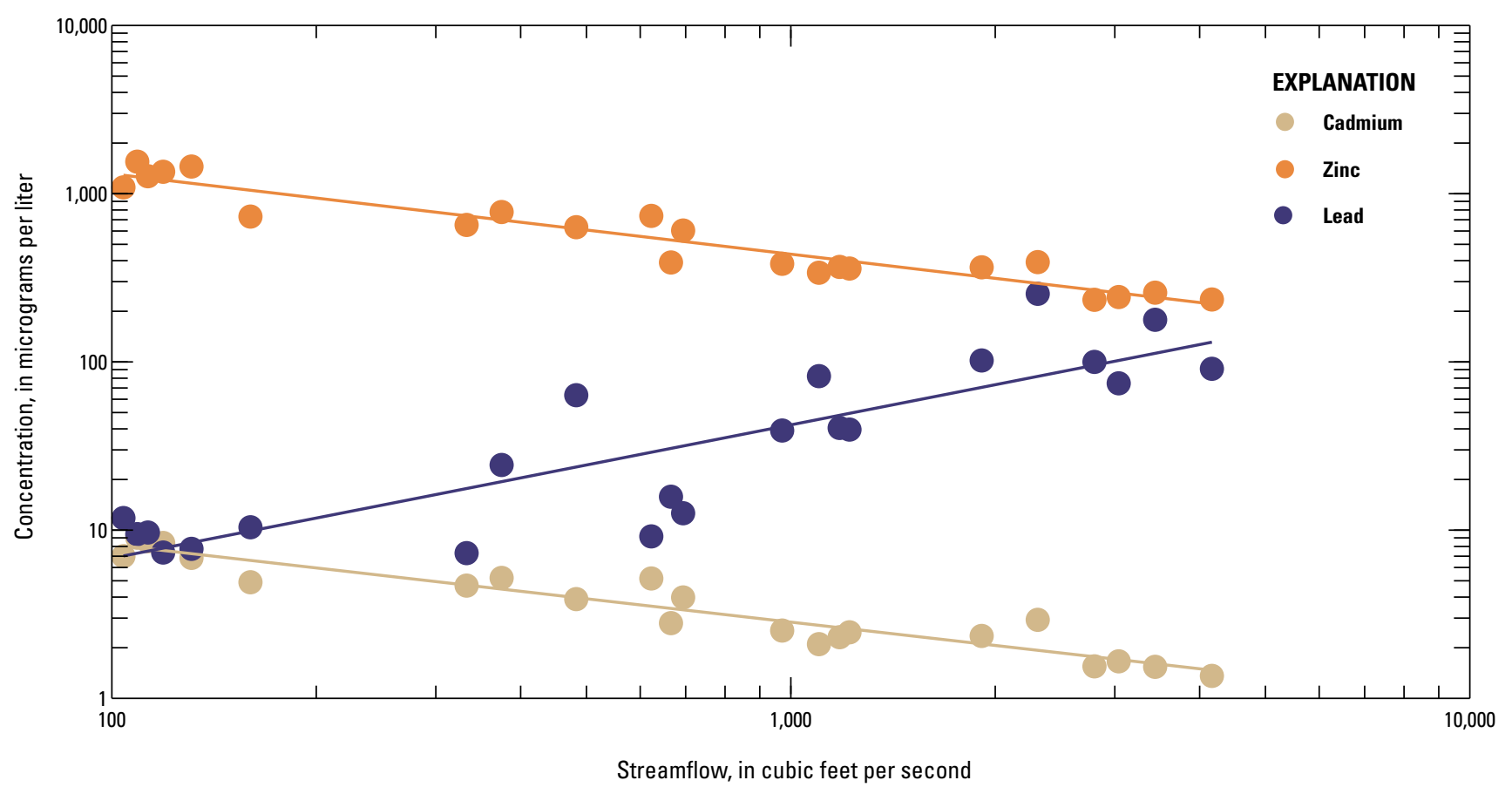

Figure 3. Relation of total cadmium, zinc, and lead concentrations to variations in streamflow in the South Fork Coeur d'Alene River near Pinehurst, Idaho (streamflow-gaging and water-quality sampling site 13), water years 2009-13.

LOADEST was used for this study to develop regression models for estimating the streamflow-weighted concentrations and loads of cadmium, zinc, lead, TP, and TN for each of the 18 BEMP sites. All available data for WYs 2003-13 were used to calibrate the regression models. However, streamflow-weighted concentrations and constituent loads were estimated only for WYs 2009-13 to represent the most recent conditions. The equation for the regression models is:

where

$$
\begin{aligned}
\ln L & =I+a(\ln Q)+b\left(\ln Q^{2}\right)+c[\sin (2 \pi T)] \\
& +d[\cos (2 \pi T)]+e(T)+\varepsilon
\end{aligned}
$$

$$
\begin{array}{cl}
L & \text { is the constituent load, in pounds per day; } \\
I & \text { is the regression intercept; } \\
Q & \begin{array}{r}
\text { is the centered streamflow, in cubic feet per } \\
\text { second; }
\end{array} \\
T & \begin{array}{r}
\text { is the centered decimal time in years from the } \\
\text { beginning of the calibration period; } \\
\text { are regression coefficients that remain } \\
\text { constant over time; and }
\end{array} \\
\varepsilon \quad \begin{array}{r}
\text { is unaccounted error associated with the } \\
\text { regression model. }
\end{array}
\end{array}
$$

For each model, the predictor variables in the regression equation were selected on the basis of Akaike Information
Criteria (Akaike, 1981; Judge and others, 1985). The criteria are designed to achieve a good compromise between using as many predictor variables as possible to explain the variance in load while minimizing the standard error of the resulting estimates. Estimates of the daily constituent load for each site were computed using the selected model (table 7, at back of report) and daily mean streamflow. Bias introduced by conversion of the logarithm of load into estimates of actual load was corrected using the Bradu-Mundlak method (Bradu and Mundlak, 1970; Cohn and others, 1989; Crawford, 1991).

Interpretation of concentrations of trace metals in streams is improved by examining the mean streamflow-weighted concentration spanning a specified time period rather than individual concentrations or statistics based on a dataset of individual concentrations. A streamflow-weighted concentration is an estimate of the mean concentration in a total volume of water flowing past a site during a specific period, such as a year, or group of years. For this study, a mean streamflow-weighted concentration at each site was estimated as the constituent load during WYs 2009-13 divided by the total streamflow during WYs 2009-13. A mean streamflow-weighted concentration for each constituent was estimated for the entire 5-year study period. Loads were estimated for each water year during 2009-13, and for the entire 5-year study period. 


\section{Ambient Water-Quality Criteria}

In addition to streamflow-weighted concentrations and loads, AWQC and AWQC ratios were calculated for dissolved cadmium and dissolved zinc based on aquatic life criteria applicable in the study area. Because dissolved lead seldom exceeded the AWQC at most sites, AWQC exceedences and trends for lead are not reported. The AWQC values for cadmium and zinc are expressed in micrograms per liter $(\mu \mathrm{g} / \mathrm{L})$, and are calculated on a sample-specific basis using the dissolved concentration in the water sample and the sample hardness. Hardness concentrations were estimated from the sample concentrations of calcium and magnesium, in milligrams per liter $(\mathrm{mg} / \mathrm{L})$ using the following equation (Weiner, 2012):

$$
\begin{aligned}
\operatorname{Hardness}(\mathrm{mg} / \mathrm{L}) & =[2.497 \times \text { dissolved calcium }(\mathrm{mg} / \mathrm{L})] \\
& +[4.118 \times \text { dissolved magnesium }(\mathrm{mg} / \mathrm{L})]
\end{aligned}
$$

Comparisons of measured cadmium and zinc AWQC values are complicated because different criteria apply across the study area, and differ from national recommended criteria developed by the EPA (Idaho Department of Environmental Quality, various dates; U.S. Environmental Protection Agency, 2002b). Site-specific criteria applicable to the SFCDR watershed have been adopted only by the State of Idaho based on the tested sensitivities of native aquatic organisms to cadmium and zinc in short- and long-term exposures in SFCDR water (Windward Environmental, 2002; Mebane, 2003; Mebane and others, 2008, 2012). The statewide cadmium criteria is from Mebane (2006) and the statewide zinc criteria is from U.S. Environmental Protection Agency (2002b).

For this assessment, chronic AWQC concentrations were based on the applicable State of Idaho chronic criteria for the protection of aquatic life (Idaho Department of Environmental Quality, various dates). Representative chronic criteria values for the Idaho statewide chronic AWQC and the SFCDR Basin chronic AWQC for a range of hardness values commonly present in the Coeur d'Alene and Spokane River Basins are given in table 2.

Cadmium and zinc chronic AWQC ratios were calculated as the concentration of dissolved cadmium or zinc in the water sample divided by the chronic AWQC. A chronic AWQC ratio of 1 or less indicates that the water-quality criteria were met. A chronic AWQC ratio of greater than 1 indicates that water-quality criteria were exceeded. For this assessment, chronic AWQC ratios were tabulated and evaluated for trends.

\section{Trend Testing}

Historical trends in trace-metal concentrations in the SFCDR at Elizabeth Park (site 8) and the SFCDR near Pinehurst (site 13), the CDR near Harrison (site 15), and
Table 2. Variation of chronic Ambient Water Quality Criteria for cadmium and zinc based on a range of hardness concentrations in the South Fork Coeur d'Alene River Basin and other parts of the Coeur d'Alene and Spokane River Basins, northern Idaho.

[Source: Idaho Department of Environmental Quality (various dates). Dissolved lead concentrations rarely exceeded the Ambient Water Quality Criteria (AWQC) and are not reported. Abbreviations: mg/L, milligram per

\begin{tabular}{|c|c|c|c|c|}
\hline \multirow[b]{2}{*}{$\begin{array}{c}\text { Hardness } \\
\text { (mg/L) }\end{array}$} & \multicolumn{2}{|c|}{ Cadmium ( $\mu \mathrm{g} / \mathrm{L}$ ) } & \multicolumn{2}{|c|}{ Zinc ( $\mu g / L)$} \\
\hline & $\begin{array}{c}\text { Idaho } \\
\text { statewide } \\
\text { chronic } \\
\text { AWQC }\end{array}$ & $\begin{array}{l}\text { SFCDR } \\
\text { Basin } \\
\text { chronic } \\
\text { AWOC }\end{array}$ & $\begin{array}{c}\text { Idaho } \\
\text { statewide } \\
\text { chronic } \\
\text { AWQC }\end{array}$ & $\begin{array}{c}\text { SFCDR } \\
\text { Basin } \\
\text { chronic } \\
\text { AWOC }\end{array}$ \\
\hline 10 & 0.14 & 0.19 & 36 & 42 \\
\hline 20 & 0.22 & 0.31 & 36 & 67 \\
\hline 35 & 0.30 & 0.47 & 49 & 97 \\
\hline 50 & 0.37 & 0.62 & 66 & 123 \\
\hline 100 & 0.55 & 1.03 & 118 & 195 \\
\hline 120 & 0.61 & 1.18 & 138 & 220 \\
\hline
\end{tabular}
liter; $\mu \mathrm{g} / \mathrm{L}$, microgram per liter; SFCDR, South Fork Coeur d'Alene River]

the Spokane River near Post Falls (site 18) were evaluated using concentration data collected from WYs 1990-2013. A Seasonal Kendall test (Helsel and Hirsch, 1992) was used to assess trends in total concentrations of cadmium, lead, and zinc, and chronic AWQC ratios for dissolved cadmium and zinc. The Seasonal Kendall test is a modified version of the nonparametric Mann-Kendall trend test (Mann, 1945) that computes a Kendall's tau non-parametric correlation coefficient and its test of significance, or p-value (Helsel and Hirsch, 1992). The Mann-Kendall test has been used extensively to analyze for trends in a broad range of environmental sciences and has been applied to various media in many different locations (Helsel and others, 2006). The Seasonal Kendall trend test accounts for seasonality by computing the Mann-Kendall test on separate user-defined seasons and combining the seasonal results (Helsel and Hirsch, 1992). The Seasonal Kendall test is independent of the distribution of samples and does not require uniform spacing between the sample results. This feature of the test is important because of the inconsistent pattern in which samples were collected during the sampling period.

Prior to testing for trend, a Locally Weighted Scatterplot Smooth (LOWESS) (Hirsch and others, 1991) and a smoothness coefficient of 0.8 was applied to the concentration data to describe the relation between the trace-metal concentration and streamflow. Residuals from this relation were "streamflow-adjusted" concentrations. The Seasonal Kendall test then was applied to the streamflow-adjusted concentrations, thereby removing the effect of streamflow. Seasonality in the data was accounted for by computing the Mann-Kendall test on each of four seasons separately, and then combining the results. A visual inspection of the trace-metal 
data indicates obvious downward trends in concentrations of trace metals from WYs 1990 through about 2002, followed by an apparent levelling off of concentrations through 2013. Tests for trend were evaluated for WYs 1990-2013, or the part of that period for which data were available, and for WYs 2003-13 to isolate the last decade and to examine for trends during the period when concentration decreases were not as apparent. A trend in concentration was considered to be significant if the probability value (p-value) from the Seasonal Kendall test was less than 0.05 .

\section{Quality Assurance}

Quality-control (QC) samples are an important part of the BEMP quality-assurance (QA) plan and a necessary component for producing scientifically defensible data (U.S. Environmental Protection Agency, 2004). Samples for QC were collected to evaluate the reliability and reproducibility of the environmental data and can be used to identify, quantify, and document potential variability and bias, two types of errors associated with environmental data (U.S. Geological Survey, various dates). About 20 percent of the samples collected during WYs 2009-13 were dedicated to QA, and consisted of field blanks and split replicates. The collection of field blanks and split replicates was rotated between sites to ensure that most of the sites were incorporated in the QA program.

During WYs 2009-13, 33 field blanks (table 3) were collected at 13 different sites. Contamination in the environmental samples can occur during collection, processing, and laboratory analyses, and the field blanks were used to identify potential contamination. The field blanks were samples of inorganic-free blank water certified as contaminant free. The blanks were subjected to the same processing (splitting, filtration, preservation, transportation, and laboratory handling) as the environmental samples, and were analyzed for the same constituents. To evaluate the potential bias in the environmental data, the concentration for each detected constituent in the field blanks was compared to the mean streamflow-weighted concentration of the constituent in the environmental samples collected at the site during WYs 2009-13. Generally, if potential contamination was less than 10 percent of the measured concentration from the environmental samples, the effect of contamination bias on the analyte concentration was considered inconsequential (Mueller, 1998).

Table 3. Results from field blanks and split replicate quality-control samples collected in the Coeur d'Alene and Spokane River Basins, northern Idaho, water years 2009-13.

[Abbreviations: RPD, relative percent difference; $\mathrm{mg} / \mathrm{L}$, milligram per liter, $\mu \mathrm{g} / \mathrm{L}$, microgram per liter; >, greater than; <, less than]

\begin{tabular}{|c|c|c|c|c|c|c|c|c|c|}
\hline \multirow[b]{2}{*}{ Constituent } & \multicolumn{4}{|c|}{ Field blanks } & \multicolumn{5}{|c|}{ Split replicates } \\
\hline & $\begin{array}{l}\text { Number } \\
\text { of field } \\
\text { blanks }\end{array}$ & $\begin{array}{c}\text { Detection } \\
\text { limit range }\end{array}$ & $\begin{array}{l}\text { Number of } \\
\text { detections }\end{array}$ & $\begin{array}{c}\text { Maximum } \\
\text { concentration } \\
\text { detected }\end{array}$ & $\begin{array}{l}\text { Number } \\
\text { of split } \\
\text { replicates }\end{array}$ & $\begin{array}{l}\text { Median } \\
\text { relative } \\
\text { percent } \\
\text { difference }\end{array}$ & $\begin{array}{c}\text { Maximum } \\
\text { relative } \\
\text { percent } \\
\text { difference }\end{array}$ & $\begin{array}{l}\text { Number of } \\
\text { replicates } \\
\text { with RPD } \\
>20 \text { percent }\end{array}$ & $\begin{array}{c}\text { Percentage } \\
\text { of replicates } \\
\text { with RPD } \\
<10 \text { percent }\end{array}$ \\
\hline Total phosphorus & 33 & $<0.004-<0.008$ & 0 & NA & 35 & 2 & 10 & 0 & 97 \\
\hline Total nitrogen & 33 & $<0.05-<0.10$ & 1 & $0.25 \mathrm{mg} / \mathrm{L}$ & 35 & 2 & 9 & 0 & 100 \\
\hline Dissolved lead & 33 & $<0.015-<0.06$ & 6 & $0.072 \mu \mathrm{g} / \mathrm{L}$ & 35 & 1 & 20 & 0 & 100 \\
\hline Total lead & 33 & $<0.04-<0.06$ & 18 & $2.4 \mu \mathrm{g} / \mathrm{L}$ & 35 & 2 & 39 & 4 & 89 \\
\hline Dissolved zinc & 33 & $<1.4-<2.8$ & 4 & $2.4 \mu \mathrm{g} / \mathrm{L}$ & 35 & 0 & 5 & 0 & 100 \\
\hline Total zinc & 33 & $<2.4-<3.0$ & 4 & $4.4 \mu \mathrm{g} / \mathrm{L}$ & 35 & 0 & 4 & 0 & 100 \\
\hline
\end{tabular}


Results from the field blanks indicate overall acceptable results (table 3). Although detectable concentrations of total lead were measured in 18 of 33 field blanks, the detectable concentrations all represented less than the 5 percent of the mean streamflow-weighted concentration of total lead at the site. The highest detected concentration of total lead in a field blank was $2.4 \mu \mathrm{g} / \mathrm{L}$, which represented only about 4 percent of the mean-streamflow weighted concentration in the environmental samples from the same site. Similarly, for dissolved cadmium, the largest detection $(0.037 \mathrm{mg} / \mathrm{L})$ represented 2.2 percent of the mean streamflow-weighted concentration. For the other constituents the largest detections in blanks were $0.10 \mathrm{mg} / \mathrm{L}$ for total cadmium (1.6 percent of the mean steamflow-weighted concentration at the site), $0.072 \mathrm{mg} / \mathrm{L}$ for dissolved lead (3 percent), $2.4 \mathrm{mg} / \mathrm{L}$ for dissolved zinc (1.2 percent), and $4.4 \mathrm{mg} / \mathrm{L}$ for total zinc (1.9 percent). For TN, one field blank contained a concentration of $0.25 \mathrm{mg} / \mathrm{L}$, or about 88 percent of the mean streamflow-weighted concentration of the environmental samples from the site. Although this is an unacceptably large concentration in a field blank, it was the only detection of TN out of 33 field blanks collected (table 3 ).

During WYs 2009-13, 35 split replicate samples were collected at 14 sites. The split replicates consisted of an environmental sample and a replicate, and were used to identify and quantify the variability in the sample collection, processing, and laboratory analysis procedures. Samples were collected by splitting a single composited sample into two subsamples for separate analysis. Each subsample was processed and preserved in an identical manner and submitted as a separate sample for analysis. The replicates were evaluated by examining the relative percent difference (RPD) between sample concentrations in relation to the replicate mean. The RPD was calculated as:

$$
\mathrm{RPD}=\left[\left(\begin{array}{c}
\text { (concentration in sample } 1) \\
-\left(\begin{array}{c}
\text { concentration in sample } 2) \\
\text { /mean concentration }
\end{array}\right)
\end{array}\right] \times 100\right.
$$

Replicate samples were considered acceptable if the RPD was less than 20 percent, or if both analyte concentrations were less than the reporting level. The reproducibility of individual constituents was evaluated for the dataset as a whole using the replicate-sample results. The reproducibility of an individual constituent was considered acceptable if 90 percent of the replicate concentrations for that constituent had RPDs that were less than 10 percent.

Results from the split replicates indicate that only dissolved cadmium (1 set) and total lead (4 sets) had at least one replicate with a RPD greater than 20 percent (dissolved lead had one replicate with a RPD of 20 percent) (table 3). All constituents met the general reproducibility requirement of having more than 90 percent of split replicates with a RPD of less than 10 percent with the exception of total lead, for which 89 percent of the splits had RPDs less than 10 percent (table 3 ).
The number of detectable concentrations of total lead in the field blanks and the relatively large RPDs for total lead in the replicate splits probably is associated with equipment cleaning or sample collection and processing procedures. Lead is often associated with sediment, so it is likely that the field blanks with detectable concentrations of total lead contained small amounts of sediment. Similarly, split replicates with high RPDs for total lead may represent samples that received different amounts of sediment during splitting and processing of the samples in the field. Fortunately, the concentrations of total lead in the field blanks were low relative to concentrations in the environmental samples, and most of the split replicates generally were within acceptable RPDs.

\section{Transport and Trends for Trace Metals and Nutrients}

The occurrence and transport of trace metals and nutrients in the Coeur d'Alene and Spokane River Basins is controlled primarily by the constituent source and input rate, the tendency of the constituent to adhere to sediment, and the transport of water and sediment through the basins. Sources of trace metals in the SFCDR, CDR, and Spokane River include adits and tailings in headwater streams and tributaries, groundwater inflow, overland runoff from flood plains, and erosion of streambank and streambed materials. Sources of nutrients include wastewater treatment outfalls, ground water contributions from septic systems, and overland runoff. After chemical constituents are mobilized in streams and rivers, they can be redistributed in aquatic systems, especially during periods of high streamflow when transport is at a maximum.

During WYs 2009-13 (October 2008-September 2013), streamflows in the Coeur d'Alene and Spokane River Basins - as represented by streamflow-gaging and waterquality sampling sites on the SFCDR near Pinehurst (site 13), the CDR near Cataldo (site 14), and the Spokane River near Post Falls (site 18) - were variable in relation to the 25-year historical mean during WYs 1989-2013 (fig. 4). Streamflow during WYs 2011 and 2012 generally exceeded the 25-year historical mean during much of the year, especially during the snowmelt runoff in the spring and early summer. During WY 2010, streamflow was less than the mean for most of the year, exceeding the historical mean only during a brief period following snowmelt runoff in the late spring and early summer. Water years 2009 and 2013 represented streamflow conditions similar to the 25-year historical mean, although both years had upward spikes in streamflow resulting from autumn and winter rain-on-snow events. A major rain-on-snow event occurred throughout northern Idaho in January 2011, producing dramatic upward spikes in streamflows at numerous sites. 

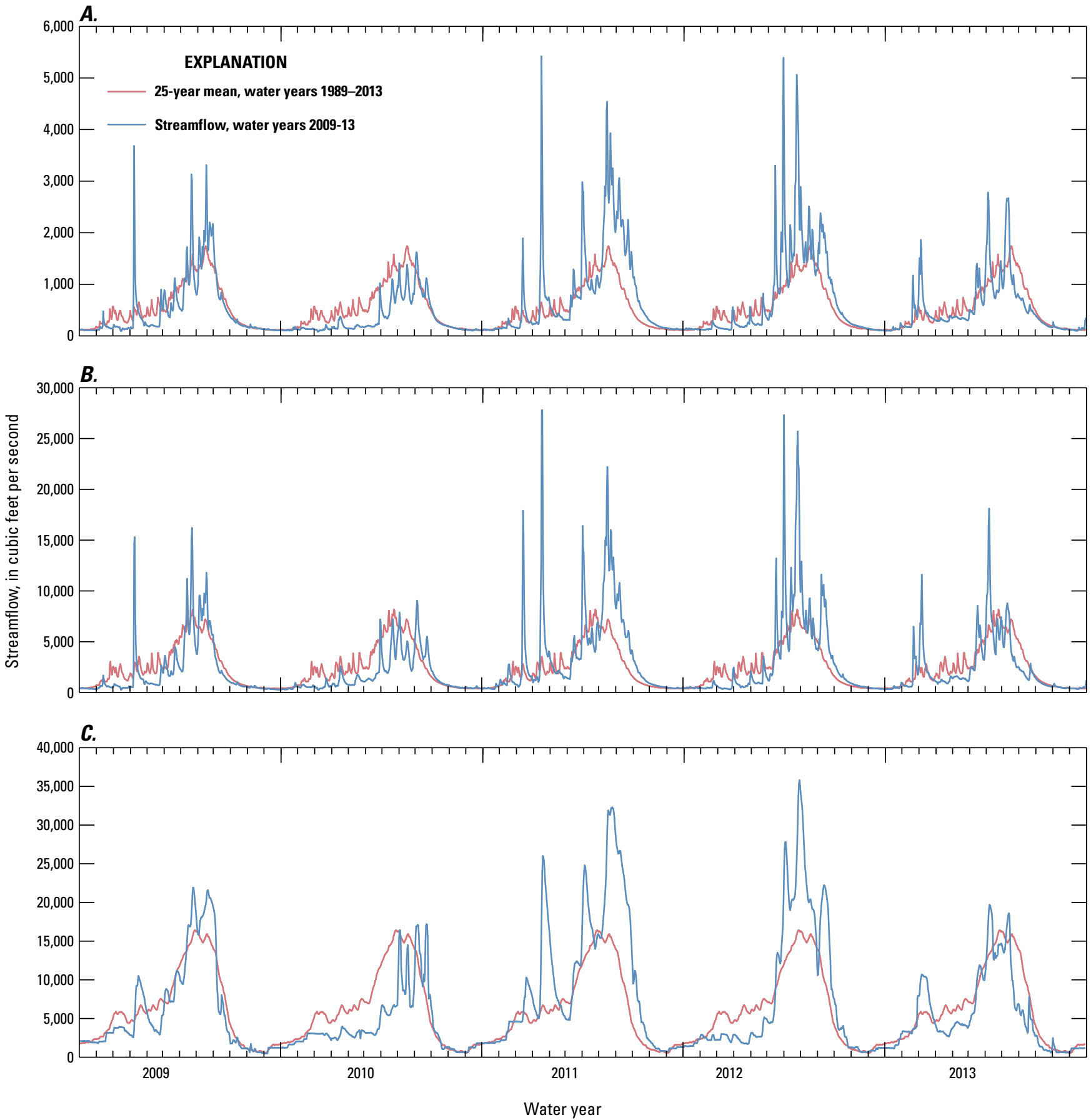

Figure 4. Daily mean streamflow at streamflow-gaging and water-quality sampling sites at $(A)$ South Fork Coeur d'Alene River near Pinehurst (site 13), (B) Coeur d'Alene River near Cataldo (site 14), and (C) Spokane River near Post Falls (site 18), Idaho, water years 2009-13, compared with the 25-year historical mean for water years 1989-2013. 


\section{Measured Trace-Metal and Nutrient Concentrations}

Boxplots are useful in showing the range and relative concentrations of water-quality constituents in the Coeur d'Alene and Spokane River Basins. However, when comparing site concentrations, it is important that boxplots for each site represent a range in the hydrologic conditions at the site. Although the number of samples collected at each site during WYs 2009-13 was variable (table 1), sampling typically covered the range of streamflows even when sample numbers were low (fig. 2). For instance, although only seven samples were collected from Pine Creek below Amy Gulch near Pinehurst (site 12) during WY 2009, the range of streamflows sampled ranged from less than 50 to more than $1,500 \mathrm{ft}^{3} / \mathrm{s}$ (fig. 2). Thus, the general range in concentrations shown in figure 5 is assumed to approximate the variability at each site.

Total and dissolved concentrations of cadmium, lead, and zinc in samples collected during WYs 2009-13 varied widely, both between sites and at individual sites (fig. 5). At most sites, dissolved cadmium and zinc represented more than 90 percent of the total concentration in the water samples (table 3). In contrast, dissolved lead represented less than 50 percent of the total concentration at all the sites, and generally was less than 10 percent. Large variability at individual sites was particularly evident in the concentrations of total lead, primarily as a response to changes in streamflow and increased amounts of suspended sediment. Concentrations of cadmium, lead, and zinc also varied widely between sites along the main stem of the SFCDR, the CDR, and the Spokane River (fig. 5).

Concentrations of cadmium, lead, and zinc increased greatly along the SFCDR from near Mullan (site 2) downstream to above Pine Creek near Pinehurst (site 11) (fig. 5). The streamflow-weighted concentrations of dissolved cadmium and zinc were more than an order of magnitude larger, and the concentration of total lead was nearly an order of magnitude larger, in the SFCDR at Wallace (site 7), as compared to the SFCDR near Mullan (site 2). Previous studies indicate that primary sources of trace-metal loading to the 9-mi reach of the SFCDR between Mullan and Wallace are Canyon and Ninemile Creeks (Clark, 2003; Donato, 2006). During the peak years of mining, at least 21 mines and mining complexes operated along Canyon Creek, and at least 9 mines operated along Ninemile Creek (National Academy of Sciences, 2005). Water discharging from these two tributaries, represented by Canyon Creek at Wallace (site 3 ) and Ninemile Creek at Wallace (site 6), contained some of the largest concentrations of cadmium, lead, and zinc in the sampling network (fig. 5).

Trace-metal concentrations remained elevated in the SFCDR from Wallace (site 7) downstream to above Pine Creek (site 11) (fig. 5). Historically, most of the large mining communities and large ore-processing facilities were located along this reach of the SFCDR. These communities (with their housing, mine-processing facilities, and transportation facilities) were built on top of and, in the case of railroad and interstate highway embankments, largely with large amounts of mine tailings deposited in this reach (National Academy of Sciences, 2005). Direct sources of trace metals to the SFCDR in the 16-mi reach between Wallace and Pine Creek include Milo Creek, Bunker Creek, Government Gulch, and groundwater discharge near the Central Impoundment Area (CIA) near Kellogg (fig. 1). The streamflow-weighted concentrations of dissolved cadmium increased by $1.81 \mu \mathrm{g} / \mathrm{L}$ (65 percent) and dissolved zinc increased by about $200 \mu \mathrm{g} / \mathrm{L}$ (45 percent) along the $1.6 \mathrm{mi}$ of the SFCDR reach bordering the CIA between Kellogg (site 9) and Smelterville (site 10). Concentrations in the SFCDR near Pinehurst (site 13) near its confluence with the NFCDR, are diluted by inflow from Pine Creek (fig. 1). Mean streamflow-weighted concentrations of total cadmium, lead, and zinc in the SFCDR near Pinehurst (site 13 ) were $3.71,61.4$, and $514 \mu \mathrm{g} / \mathrm{L}$, respectively (table 4 ).

Concentrations of cadmium, lead, and zinc decreased greatly between the SFCDR near Pinehurst (site 13) downstream to the CDR near Cataldo (site 14) in response to mixing with the relatively dilute inflow from the NFCDR (fig. 5). Mean streamflow-weighted concentrations of total cadmium, lead, and zinc in the NFCDR at Enaville (site 1) were $0.049,2.09$, and $7.75 \mu \mathrm{g} / \mathrm{L}$, respectively (table 4). Concentrations of cadmium, lead, and zinc in the CDR increased between Cataldo (site 14) and Harrison (site 15) (fig. 5), $32 \mathrm{mi}$ downstream. Although the mean flow-weighted concentrations of dissolved and total cadmium increased only slightly, the mean streamflow-weighted concentrations of dissolved and total zinc increased by about 31 (23 percent) and $98 \mu \mathrm{g} / \mathrm{L}$ (71 percent), respectively (table 4). The largest percentage increase in concentration between Cataldo and Harrison was for lead; there was about an order of magnitude increase in dissolved lead from 0.902 to about $10.8 \mu \mathrm{g} / \mathrm{L}$, and about a 5-fold increase in total lead from 22.9 to $125 \mu \mathrm{g} / \mathrm{L}$. The increase in particulate concentrations of cadmium, lead, and zinc between the SFCDR near Cataldo (site 14) and the SFCDR near Harrison (site 15) probably is attributable to increased mobilization of stored sediment and associated trace metals from the flood plain and in the river channel. Previous studies have documented large increases in suspended sediment and bedload in the lower reaches of the CDR downstream of Cataldo (Clark and Woods, 2000), especially during rain-on-snow events and during spring snowmelt runoff. Mobilization of sediment and associated trace metals probably also is responsible for the apparent increase in the streamflow-weighted concentrations of dissolved cadmium, lead, and zinc in the lower CDR. When water levels in Coeur d'Alene Lake are lowered, typically during the late summer and autumn, the hydraulic gradient between the river channel downstream to the lake increases, resulting in an increase in the stream velocity in the Coeur d'Alene River and an increase in the transport of total and dissolved cadmium, lead, and zinc. 


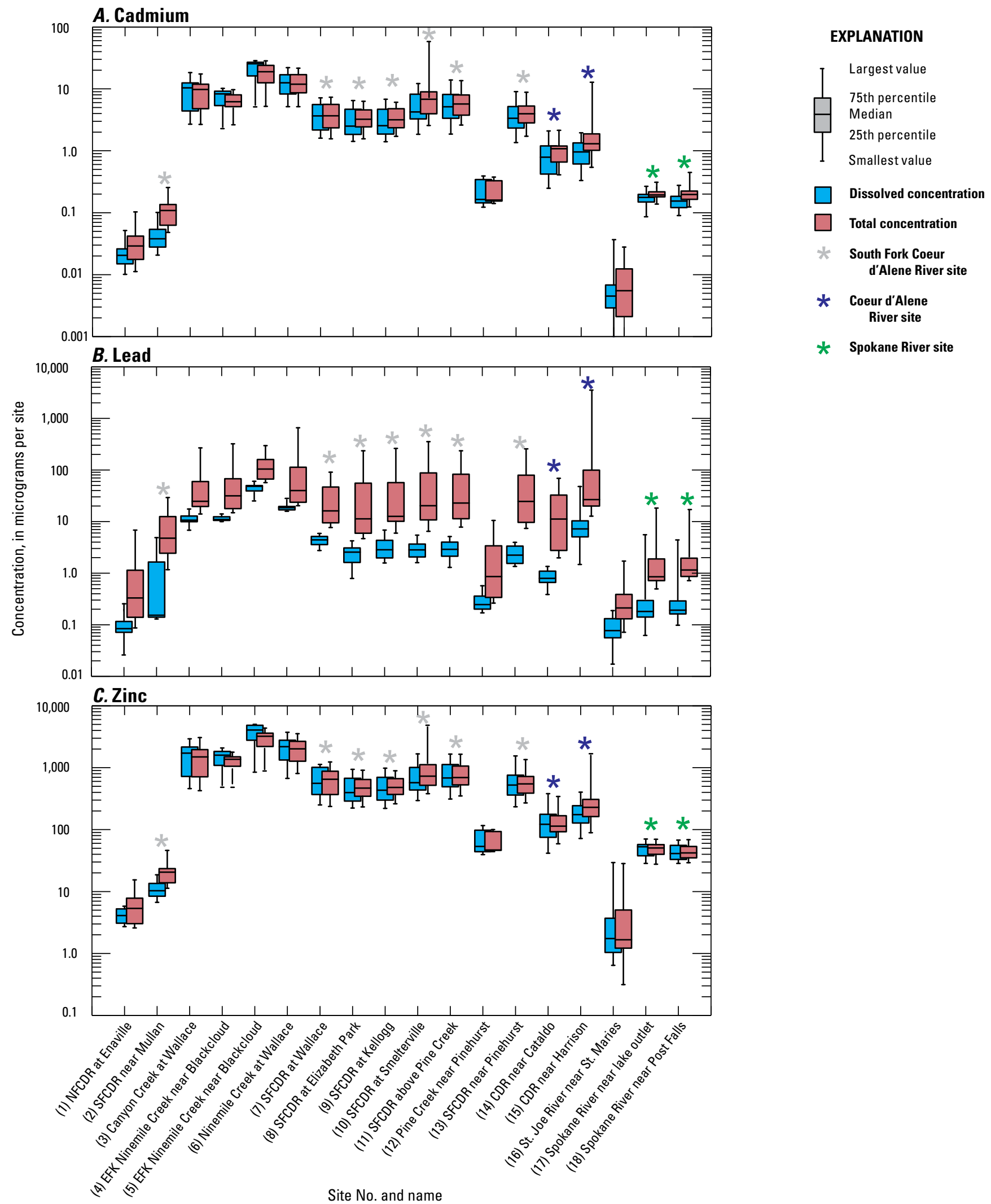

Figure 5. Dissolved and total $(A)$ cadmium, $(B)$ lead, and $(C)$ zinc concentrations in water samples collected at streamflow-gaging and water-quality sampling sites (sites 1-18) in the Coeur d'Alene and Spokane River Basins, northern Idaho, water years 2009-13. Site information is shown in table 1; site locations are shown in figure 1. 


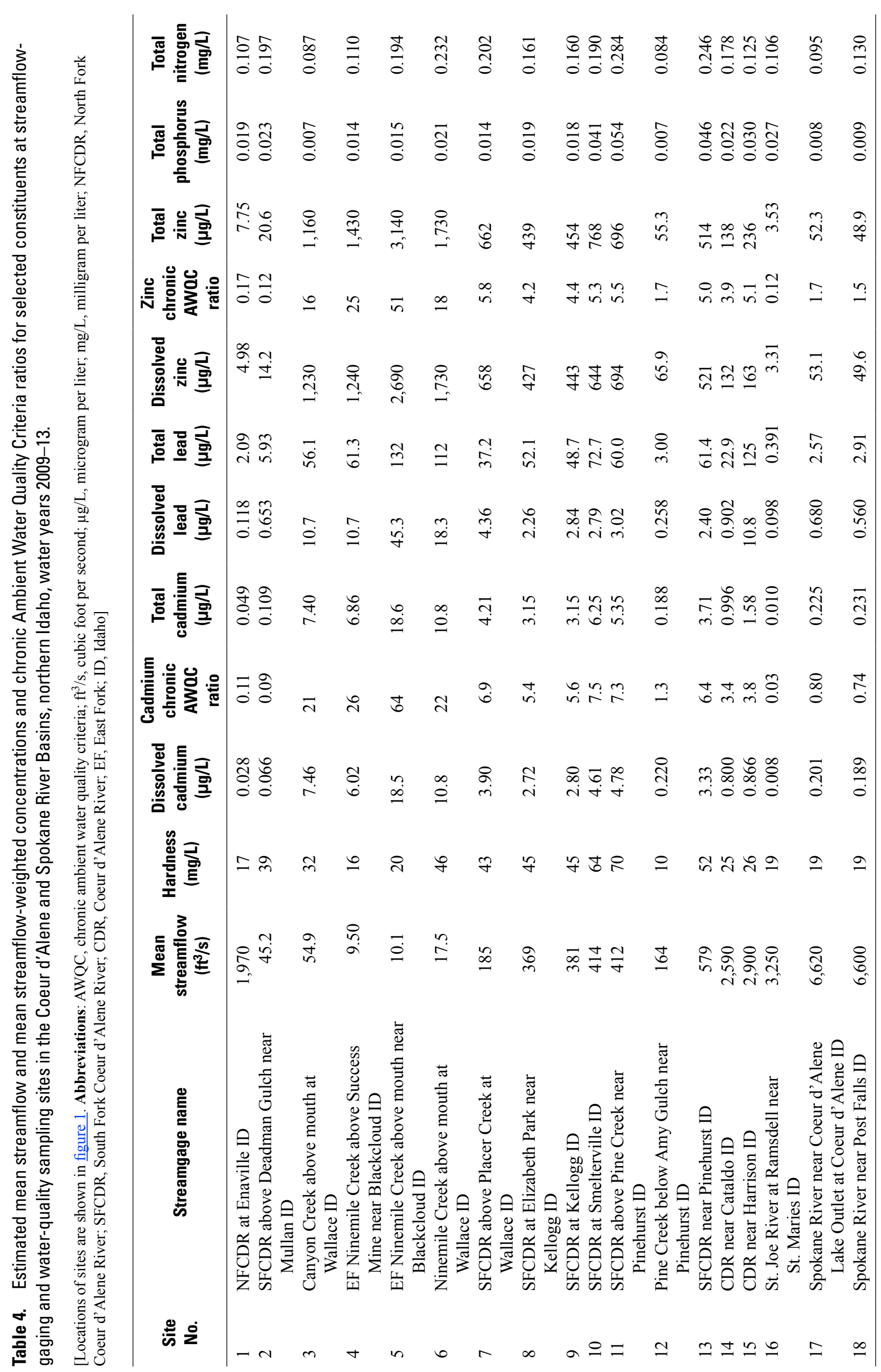


The large decreases in the concentrations of cadmium, lead, and zinc between the CDR near Harrison (site 15) and the Spokane River near the outlet of Coeur d'Alene Lake (site 17) indicates dilution and possible trapping of trace metals in Coeur d'Alene Lake. The flow-weighted concentrations of total cadmium, lead, and zinc in the Spokane River at the lake outlet (site 17) were $0.225,2.57$, and $52.3 \mu \mathrm{g} / \mathrm{L}$, respectively (table 4). The streamflow-weighted concentrations of total cadmium, lead, and zinc indicate decreases from the CDR near Harrison (site 15) to the lake outlet (site 17) of about 86,98 , and 78 percent, respectively. The concentrations of dissolved and total cadmium, lead, and zinc remained relatively constant (fig. 5, table 4) in the Spokane River from the lake outlet (site 17) downstream about $10 \mathrm{mi}$ to the Spokane River near Post Falls (site 18). The mean streamflow-weighted concentrations of total cadmium, lead, and zinc in the Spokane River near Post Falls (site 18) were $0.231,2.91$, and $48.9 \mu \mathrm{g} / \mathrm{L}$, respectively (table 4). Streamflowweighted concentrations of cadmium, lead, and zinc were the lowest in the St. Joe River near St. Maries (site 16).

The AWQC ratios indicate that cadmium and zinc concentrations generally met the chronic criteria (ratio of less than 1.0) for the protection of aquatic life at only five and three sites, respectively (ig. 6). The chronic AWQC was achieved in all the samples from the NFCDR at Enaville (site 1), the SFCDR near Mullan (site 2), and in the St. Joe River near St. Maries (site 16). Both of the sites on the Spokane River (sites 17 and 18) had mean chronic zinc AWQC ratios slightly greater than 1.0 and mean chronic cadmium AWQC ratios slightly less than 1.0 (table 4). The sites with the largest chronic AWQC ratios for both cadmium and zinc were located in the Canyon and Ninemile Creek basins.

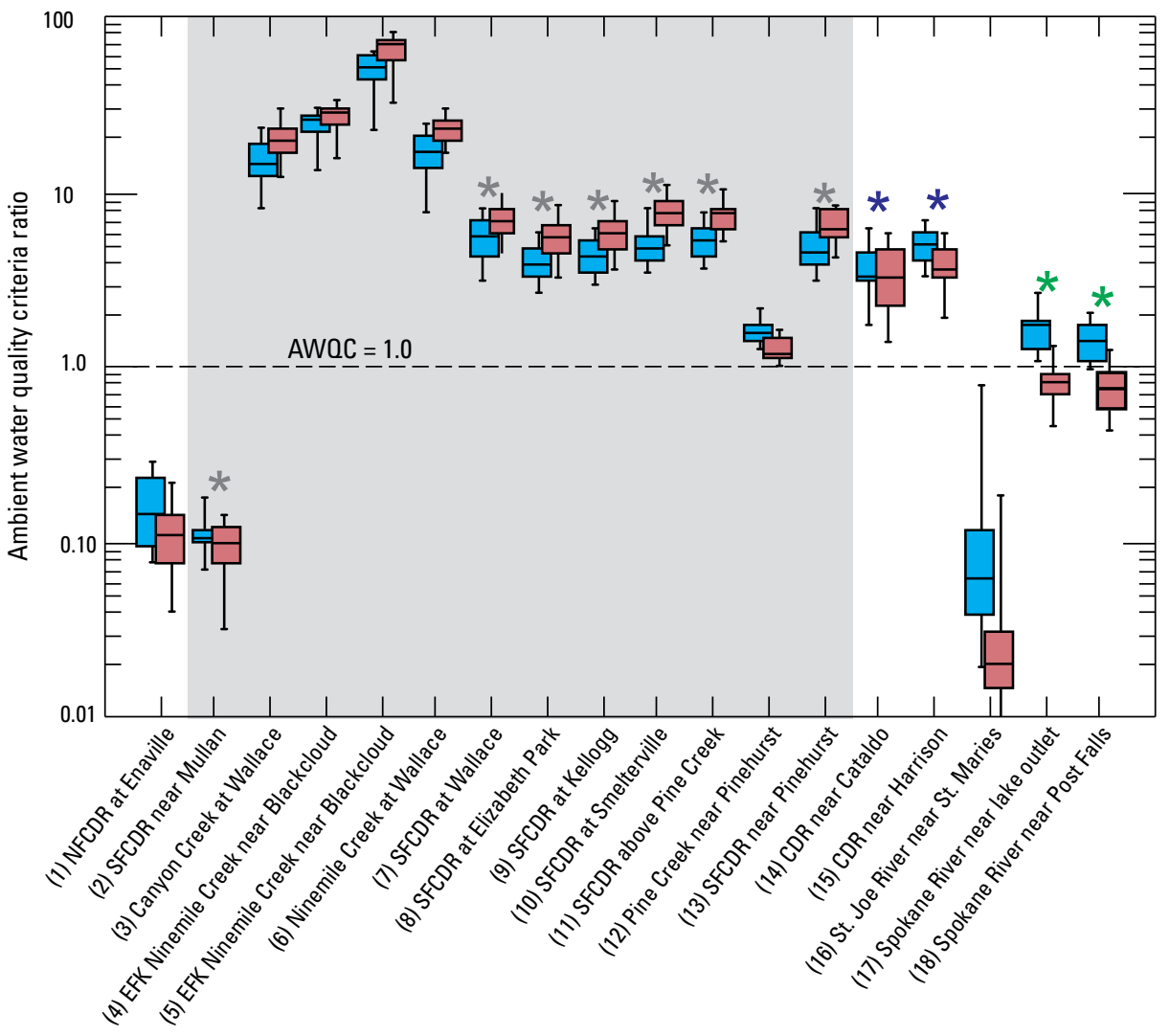

Site No. and name

Figure 6. Chronic Ambient Water Quality Criteria (AWOC) ratios for dissolved zinc and cadmium in water samples collected at streamflow-gaging and waterquality sampling sites (sites 1-18) in the Coeur d'Alene and Spokane River Basins, northern Idaho, water years 2009-13. Gray shading indicates sites in the South Fork Coeur d'Alene River (SFCDR) Basin for which AWQC were calculated using sitespecific criteria that apply only in the SFCDR Basin. Site information is shown in table 1; site locations are shown in figure 1.

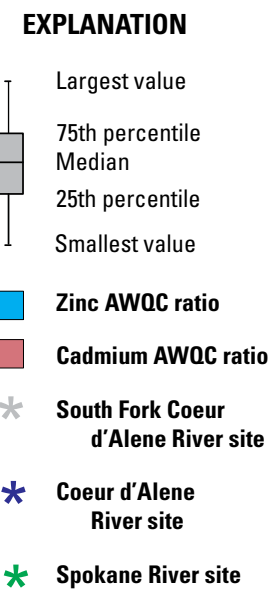


The lower East Fork Ninemile Creek near Blackcloud (site 5) had mean chronic AWQC ratios for cadmium and zinc of 64 and 51, respectively, more than twice the mean ratio of any other site in the network. The chronic AWQC ratios in the SFCDR between Wallace (site 7) downstream to near Pinehurst (site 13) were relatively consistent both spatially between sites and temporally at individual sites. Compared to other sites in the network, sites in the SFCDR Basin typically had larger mean AWQC ratios for cadmium than for zinc.
This was especially apparent in Canyon Creek (site 3), the East Fork of Ninemile Creek (sites 4 and 5), Ninemile Creek (site 6), and the SFCDR sites downstream of Canyon and Ninemile Creeks (sites 7-11 and 13). The mean AWQC ratio for zinc was larger than for cadmium in the SFCDR near Mullan (site 2), Pine Creek near Pinehurst (site 12), and all the sites outside the SFCDR Basin (sites 1 and 14-18) (fig. 6).

Concentrations of TP and TN were not as variable between sites as compared to cadmium, lead, and zinc (fig. 7).

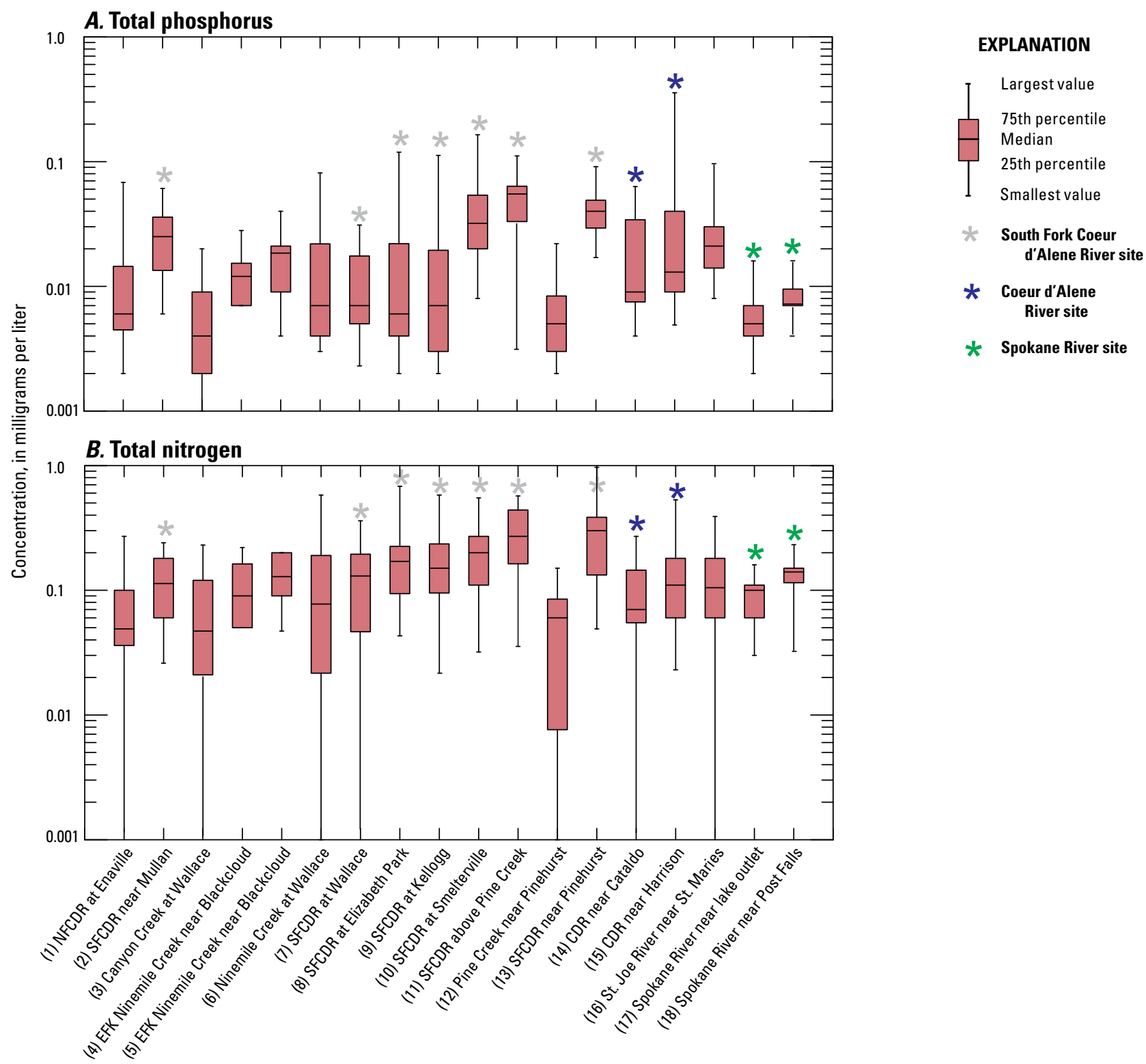

Site No. and name

Figure 7. Total $(A)$ phosphorus and $(B)$ nitrogen concentrations in water samples collected at streamflow-gaging and water-quality sampling sites in the Coeur d'Alene and Spokane River Basins, northern Idaho, water years 2009-13. 
In contrast to trace metals that are transported to the SFCDR from Canyon and Ninemile Creeks in large quantities, concentrations of TP decreased and concentrations of TN increased slightly along the SFCDR from Mullan (site 2) downstream to Wallace (site 7) (fig. 7). The largest increases in TP and TN concentrations in the SFCDR occurred between Kellogg (site 9) and above Pine Creek (site 11). In this 4-mi reach of the SFCDR, where wastewater treatment outfalls from Kellogg and other municipalities enter the SFCDR, the streamflow-weighted concentrations of TP and TN increased by $0.036 \mathrm{mg} / \mathrm{L}$ (200 percent) and $0.124 \mathrm{mg} / \mathrm{L}$ (78 percent), respectively. The mean streamflow-weighted concentrations for TP and TN peaked in the SFCDR above Pine Creek (site 11) at 0.054 and $0.284 \mathrm{mg} / \mathrm{L}$, respectively (table 4). From the SFCDR near Pinehurst (site 13) downstream to the CDR near Cataldo (site 14), the streamflow-weighted concentrations of TP and TN decreased as water from the relatively dilute North Fork Coeur d'Alene River (site 1) mixed with water from the SFCDR. Although boxplots based on individual samples (fig. 7) indicate increases in the median concentrations of TP and TN from the CDR near Cataldo (site 14) downstream to the CDR near Harrison (site 15), the mean streamflow-weighted concentration for WYs 2009-13 indicates an increase of only $0.008 \mathrm{mg} / \mathrm{L}$ of TP and a decrease of $0.053 \mathrm{mg} / \mathrm{L}$ of TN between Cataldo and Harrison (table 4). Concentrations of TP and TN in the Spokane River at the Coeur d'Alene Lake outlet (site 17) were lower than concentrations at in the CDR at Harrison (site 15) and the St. Joe River near St. Maries (site 16) (table 4). The decrease in TP and TN concentrations through the lake indicate that, as with trace metals, Coeur d'Alene Lake may be retaining these nutrients. From the Spokane River at the lake outlet (site 17) downstream to the Spokane River near Post Falls (site 18), the streamflow-weighted concentrations of TP and TN increased by 0.001 and $0.035 \mathrm{mg} / \mathrm{L}$ (table 4), respectively, in response to discharge from wastewater treatment facilities in Coeur d'Alene and Post Falls.

\section{Loading, Transport, and Deposition}

The source area contributing trace-metal and nutrient loads as measured at individual BEMP surface-water sites includes the entire watershed upstream of each site. The network design in the Coeur d'Alene and Spokane River Basins divides the basins into smaller subbasins in order to identify specific areas contributing loads of trace metals and nutrients to downstream water bodies. Thus, the relative importance of each subarea to overall loading in the Coeur d'Alene and Spokane River Basins can be estimated. Sites near the mouths of tributaries provide estimates of the integrated loads from the entire upstream basin, and main-stem sites provide estimates of incremental loading in a downstream manner. The sampling network also allows an approximation of the load of trace metals and nutrients discharged to Coeur d'Alene Lake from the Coeur d'Alene and St. Joe Rivers, the load retained within the lake, and the load transported from the lake downstream in the Spokane River.

Annual trace-metal and nutrient loads for each of the 18 sites in the BEMP network were estimated for WYs 2009-13 (table 5; table 8, at back of report). The loads can be used to determine the incremental gains and (or) losses of load along main-stem reaches of the SFCDR, CDR, and Spokane Rivers. The estimates were based on the difference in load between main-stem sites and measured tributaries in each reach. The gains and (or) losses in load that were unaccounted for by the sampling network are referred to as "unmeasured." In main-stem reaches with unmeasured streamflow and unmeasured loads, the mean streamflow-weighted concentration of the unmeasured source (or sources) can be estimated as the unmeasured load divided by the unmeasured streamflow and multiplied by an appropriate conversion factor. Primary sources of unmeasured trace metals and nutrients are ungaged and unsampled tributaries and drains, groundwater discharge to surface water, overland flow, and dissolution and erosion of material in stream channels.

\section{South Fork Coeur d'Alene River}

The first major inflows to the SFCDR downstream of Mullan (site 2) are Canyon Creek (site 3) and Ninemile Creek (site 6). Combined, these two tributaries contributed estimated mean loads of about 0.575 ton per year (ton/yr) of total cadmium, 5.29 ton/yr of total lead, and 90.9 ton/yr of total zinc to the SFCDR during WYs 2009-13 (table 8). Although combined, these two tributaries contributed only about 39 percent of the mean annual streamflow as measured in the SFCDR at Wallace (site 7) (fig. 8A), they accounted for about 79 percent of the mean annual load of total cadmium (fig. $8 B$ ), 77 percent of the mean annual load of total lead (fig. 8C), and 80 percent of the mean annual load of total zinc (fig. 8D). About 36 percent of the mean annual streamflow, and 20, 19, and 20 percent of the mean annual loads of cadmium, lead, and zinc, respectively, in the SFCDR at Wallace (site 7) were from unmeasured sources. These unmeasured sources entering the SFCDR between Mullan (site 2) and Wallace (site 7) had mean concentrations of $2.2 \mu \mathrm{g} / \mathrm{L}$ of total cadmium, $20 \mu \mathrm{g} / \mathrm{L}$ of total lead, and $340 \mu \mathrm{g} / \mathrm{L}$ of total zinc. All the cadmium and zinc, and about 62 percent of the lead discharging to the SFCDR from Ninemile Creek at Wallace (site 6), were attributable to the East Fork of Ninemile Creek above the mouth near Blackcloud (site 5) (figs. $8 B-\underline{D}$ ). 
Table 5. Annual loads of total phosphorus and total nitrogen and 95-percent confidence intervals for streamflow-gaging and waterquality sampling sites in the Coeur d'Alene and Spokane River Basins, northern Idaho, water years 2009-13.

[Locations of sites are shown in figure 1. Abbreviations: ton/yr, ton per year; C.I., confidence interval; NFCDR, North Fork Coeur d'Alene River; SFCDR, South Fork Coeur d'Alene River; CDR, Coeur d'Alene River; EF, East Fork; ID, Idaho]

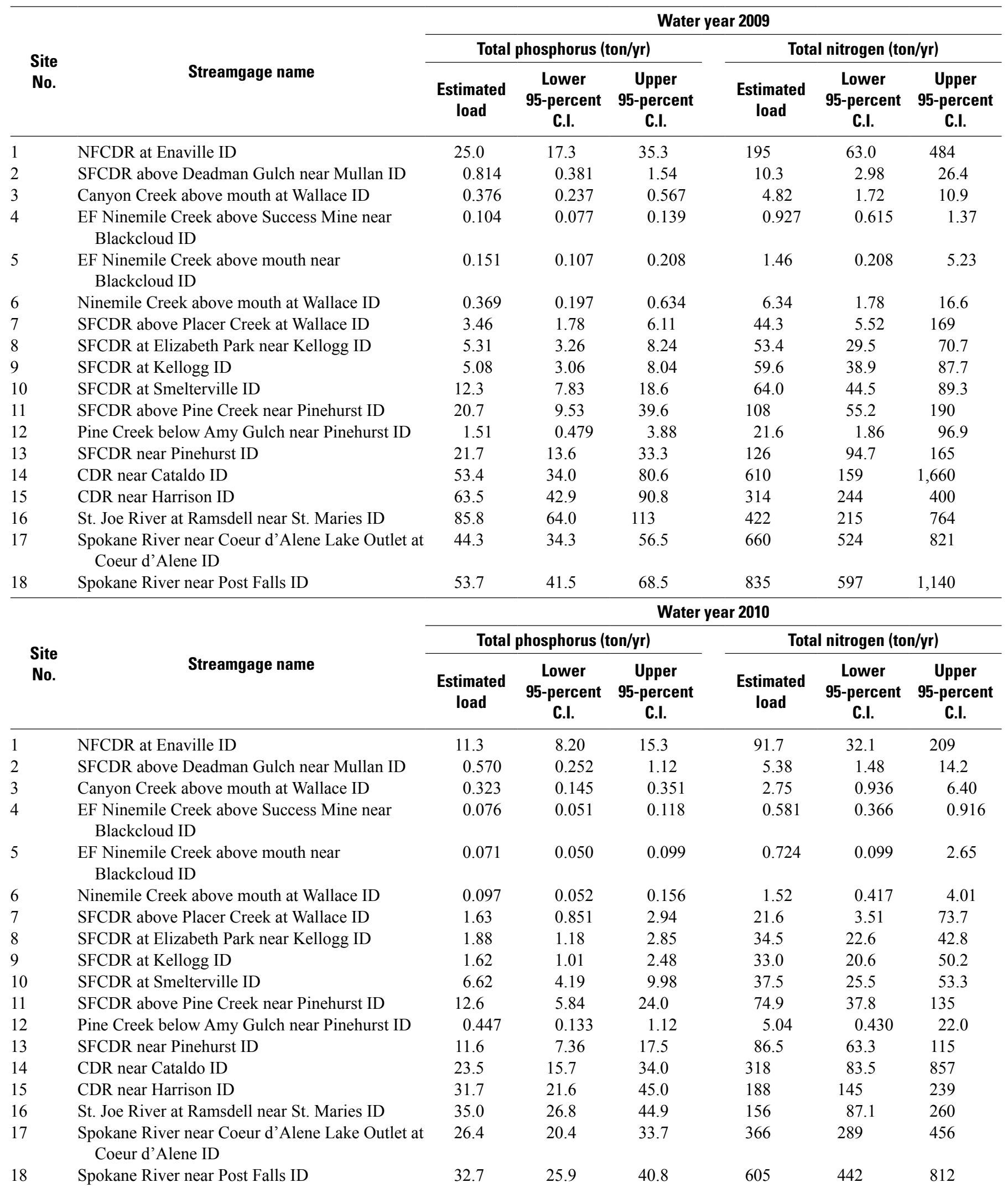


Table 5. Annual loads of total phosphorus and total nitrogen and 95-percent confidence intervals for streamflow-gaging and waterquality sampling sites in the Coeur d'Alene and Spokane River Basins, northern Idaho, water years 2009-13._- Continued

[Locations of sites are shown in figure 1. Abbreviations: ton/yr, ton per year; C.I., confidence interval; NFCDR, North Fork Coeur d'Alene River; SFCDR, South Fork Coeur d'Alene River; CDR, Coeur d'Alene River; EF, East Fork; ID, Idaho]

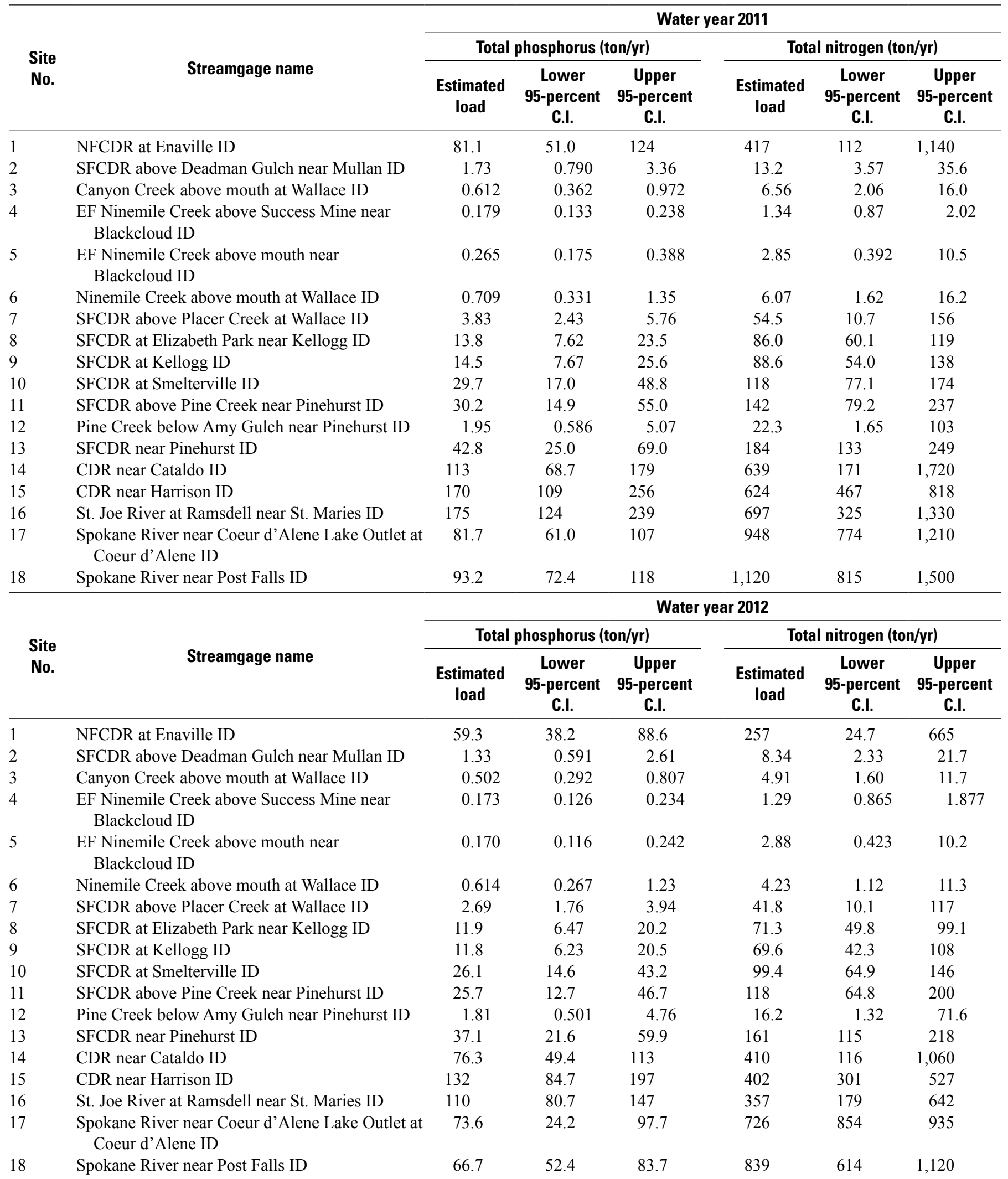


Table 5. Annual loads of total phosphorus and total nitrogen and 95-percent confidence intervals for streamflow-gaging and waterquality sampling sites in the Coeur d'Alene and Spokane River Basins, northern Idaho, water years 2009-13. - Continued

[Locations of sites are shown in figure 1. Abbreviations: ton/yr, ton per year; C.I., confidence interval; NFCDR, North Fork Coeur d'Alene River; SFCDR, South Fork Coeur d'Alene River; CDR, Coeur d'Alene River; EF, East Fork; ID, Idaho]

\begin{tabular}{|c|c|c|c|c|c|c|c|}
\hline \multirow{3}{*}{$\begin{array}{l}\text { Site } \\
\text { No. }\end{array}$} & \multirow[b]{3}{*}{ Streamgage name } & \multicolumn{6}{|c|}{ Water year 2013} \\
\hline & & \multicolumn{3}{|c|}{ Total phosphorus (ton/yr) } & \multicolumn{3}{|c|}{ Total nitrogen (ton/yr) } \\
\hline & & $\begin{array}{l}\text { Estimated } \\
\text { load }\end{array}$ & $\begin{array}{c}\text { Lower } \\
\text { 95-percent } \\
\text { C.I. }\end{array}$ & $\begin{array}{c}\text { Upper } \\
\text { 95-percent } \\
\text { C.I. }\end{array}$ & $\begin{array}{l}\text { Estimated } \\
\text { load }\end{array}$ & $\begin{array}{c}\text { Lower } \\
\text { 95-percent } \\
\text { C.I. }\end{array}$ & $\begin{array}{c}\text { Upper } \\
\text { 95-percent } \\
\text { C.I. }\end{array}$ \\
\hline 1 & NFCDR at Enaville ID & 23.5 & 15.5 & 34.1 & 131 & 38.3 & 334 \\
\hline 2 & SFCDR above Deadman Gulch near Mullan ID & 0.914 & 0.329 & 2.07 & 6.53 & 1.34 & 20.1 \\
\hline 3 & Canyon Creek above mouth at Wallace ID & 0.314 & 0.174 & 0.525 & 4.49 & 1.30 & 11.4 \\
\hline 4 & $\begin{array}{l}\text { EF Ninemile Creek above Success Mine near } \\
\text { Blackcloud ID }\end{array}$ & 0.112 & 0.077 & 0.159 & 0.991 & 0.592 & 1.59 \\
\hline 5 & $\begin{array}{l}\text { EF Ninemile Creek above mouth near } \\
\text { Blackcloud ID }\end{array}$ & 0.111 & 0.067 & 0.174 & 2.09 & 0.288 & 7.61 \\
\hline 6 & Ninemile Creek above mouth at Wallace ID & 0.212 & 0.099 & 0.401 & 2.33 & 0.554 & 6.60 \\
\hline 7 & SFCDR above Placer Creek at Wallace ID & 1.35 & 0.843 & 2.07 & 24.5 & 4.91 & 75.6 \\
\hline 8 & SFCDR at Elizabeth Park near Kellogg ID & 5.41 & 3.04 & 8.91 & 52.9 & 36.3 & 74.6 \\
\hline 9 & SFCDR at Kellogg ID & 4.97 & 2.70 & 8.43 & 54.4 & 29.9 & 82.5 \\
\hline 10 & SFCDR at Smelterville ID & 14.1 & 8.15 & 22.7 & 77.8 & 49.7 & 117 \\
\hline 11 & SFCDR above Pine Creek near Pinehurst ID & 19.3 & 8.48 & 38.1 & 116 & 56.7 & 214 \\
\hline 12 & Pine Creek below Amy Gulch near Pinehurst ID & 0.498 & 0.119 & 1.42 & 5.32 & 0.36 & 24.8 \\
\hline 13 & SFCDR near Pinehurst ID & 22.2 & 12.8 & 36.1 & 133 & 92.3 & 185 \\
\hline 14 & CDR near Cataldo ID & 34.4 & 21.0 & 53.6 & 231 & 56.8 & 646 \\
\hline 15 & CDR near Harrison ID & 70.3 & 45.1 & 105 & 315 & 234 & 416 \\
\hline 16 & St. Joe River at Ramsdell near St. Maries ID & 58.7 & 43.2 & 78.1 & 170 & 86.0 & 302 \\
\hline 17 & $\begin{array}{l}\text { Spokane River near Coeur d'Alene Lake Outlet at } \\
\text { Coeur d'Alene ID }\end{array}$ & 38.4 & 28.5 & 50.6 & 439 & 335 & 565 \\
\hline 18 & Spokane River near Post Falls ID & 38.9 & 30.0 & 49.6 & 700 & 497 & 962 \\
\hline \multirow{3}{*}{$\begin{array}{l}\text { Site } \\
\text { No. }\end{array}$} & \multirow[b]{3}{*}{ Streamgage name } & \multicolumn{6}{|c|}{ Water years 2009-13 (mean) } \\
\hline & & \multicolumn{3}{|c|}{ Total phosphorus (ton/yr) } & \multicolumn{3}{|c|}{ Total nitrogen (ton/yr) } \\
\hline & & $\begin{array}{l}\text { Estimated } \\
\text { load }\end{array}$ & $\begin{array}{c}\text { Lower } \\
\text { 95-percent } \\
\text { C.I. }\end{array}$ & $\begin{array}{c}\text { Upper } \\
\text { 95-percent } \\
\text { C.I. }\end{array}$ & $\begin{array}{l}\text { Estimated } \\
\text { load }\end{array}$ & $\begin{array}{c}\text { Lower } \\
\text { 95-percent } \\
\text { C.I. }\end{array}$ & $\begin{array}{c}\text { Upper } \\
\text { 95-percent } \\
\text { C.I. }\end{array}$ \\
\hline 1 & NFCDR at Enaville ID & 40.0 & 26.0 & 59.5 & 219 & 64.0 & 566 \\
\hline 2 & SFCDR above Deadman Gulch near Mullan ID & 1.07 & 0.469 & 2.14 & 8.75 & 2.34 & 23.6 \\
\hline 3 & Canyon Creek above mouth at Wallace ID & 0.407 & 0.242 & 0.644 & 4.71 & 1.52 & 11.3 \\
\hline 4 & $\begin{array}{l}\text { EF Ninemile Creek above Success Mine near } \\
\text { Blackcloud ID }\end{array}$ & 0.129 & 0.093 & 0.177 & 1.03 & 0.660 & 1.55 \\
\hline 5 & $\begin{array}{l}\text { EF Ninemile Creek above mouth near } \\
\text { Blackcloud ID }\end{array}$ & 0.154 & 0.103 & 0.222 & 2.00 & 0.282 & 7.25 \\
\hline 6 & Ninemile Creek above mouth at Wallace ID & 0.400 & 0.189 & 0.755 & 4.10 & 1.10 & 10.9 \\
\hline 7 & SFCDR above Placer Creek at Wallace ID & 2.59 & 1.54 & 4.16 & 36.8 & 6.96 & 118 \\
\hline 8 & SFCDR at Elizabeth Park near Kellogg ID & 7.66 & 4.31 & 12.7 & 59.0 & 41.7 & 81.3 \\
\hline 9 & SFCDR at Kellogg ID & 7.59 & 4.13 & 13.0 & 60.4 & 37.1 & 93.3 \\
\hline 10 & SFCDR at Smelterville ID & 17.8 & 10.4 & 28.7 & 79.4 & 52.3 & 116 \\
\hline 11 & SFCDR above Pine Creek near Pinehurst ID & 21.7 & 10.3 & 40.7 & 112 & 58.7 & 195 \\
\hline 12 & Pine Creek below Amy Gulch near Pinehurst ID & 1.24 & 0.364 & 3.25 & 14.1 & 1.12 & 63.7 \\
\hline 13 & SFCDR near Pinehurst ID & 27.1 & 16.1 & 43.2 & 138 & 99.8 & 187 \\
\hline 14 & CDR near Cataldo ID & 60.2 & 37.8 & 92.0 & 442 & 117 & 1,190 \\
\hline 15 & CDR near Harrison ID & 93.6 & 60.6 & 139 & 369 & 278 & 480 \\
\hline 16 & St. Joe River at Ramsdell near St. Maries ID & 92.9 & 67.8 & 125 & 360 & 178 & 660 \\
\hline 17 & $\begin{array}{l}\text { Spokane River near Coeur d'Alene Lake Outlet at } \\
\text { Coeur d'Alene ID }\end{array}$ & 52.9 & 39.7 & 69.2 & 628 & 487 & 797 \\
\hline 18 & Spokane River near Post Falls ID & 57.0 & 44.4 & 72.2 & 819 & 593 & 1,110 \\
\hline
\end{tabular}




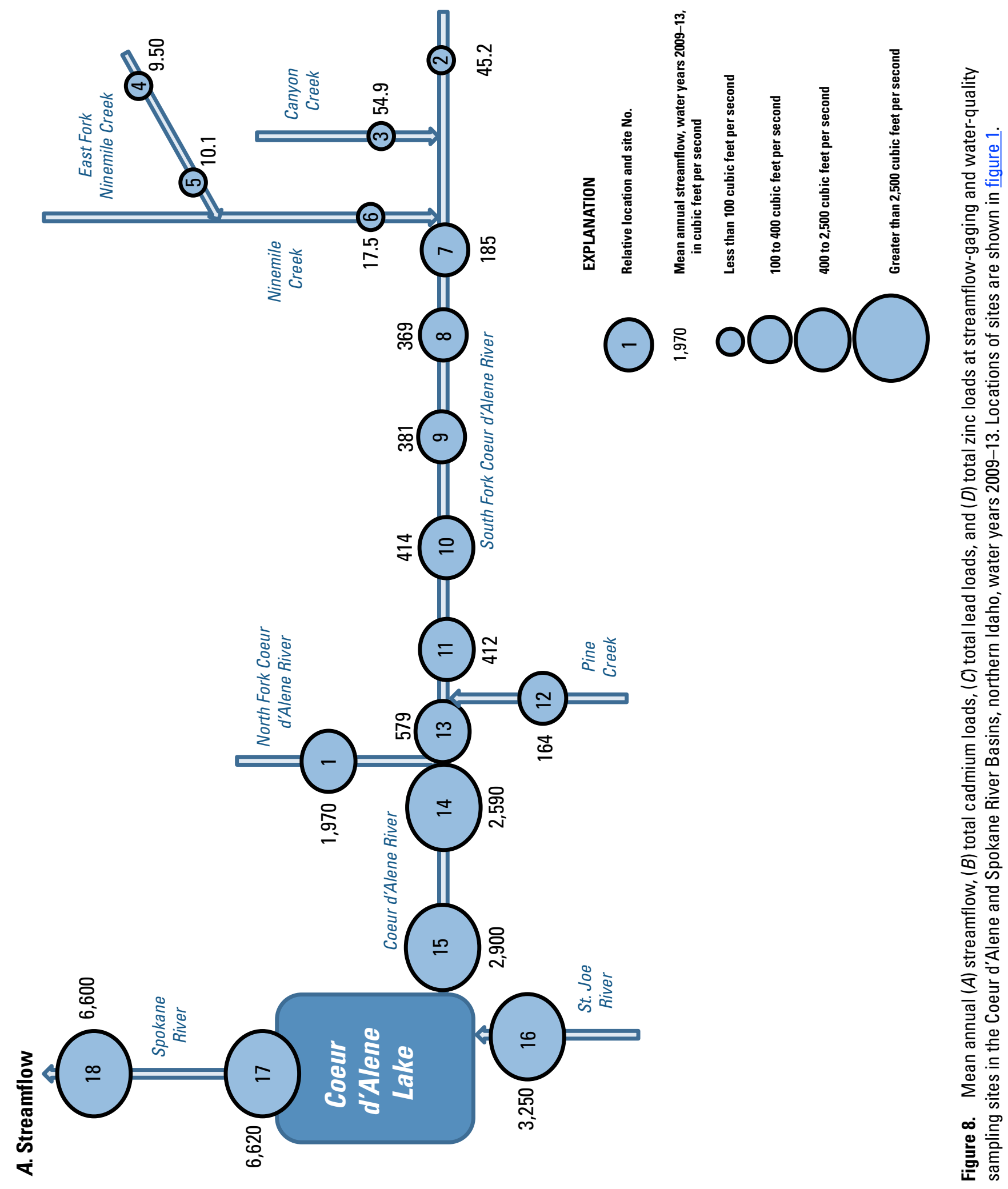




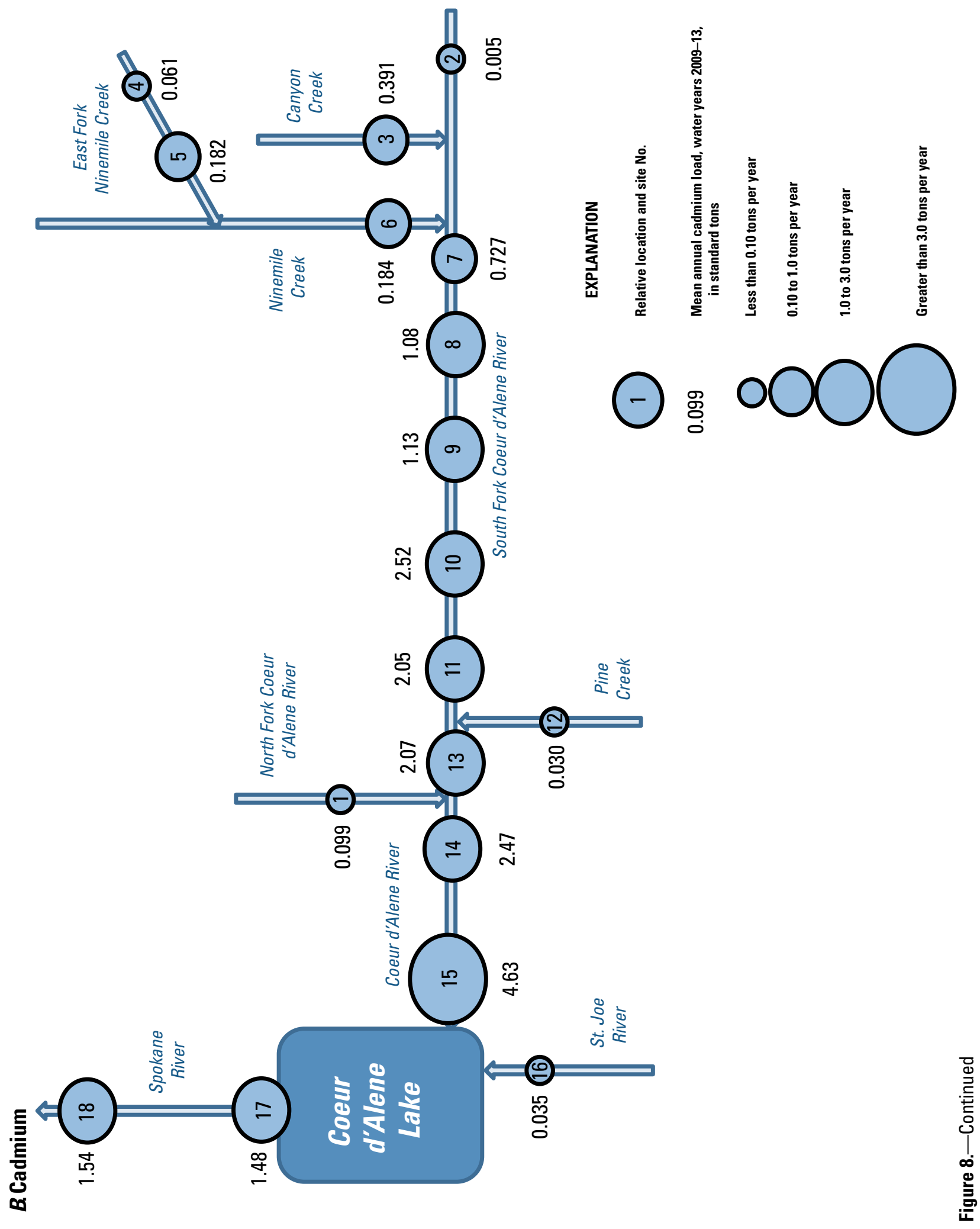




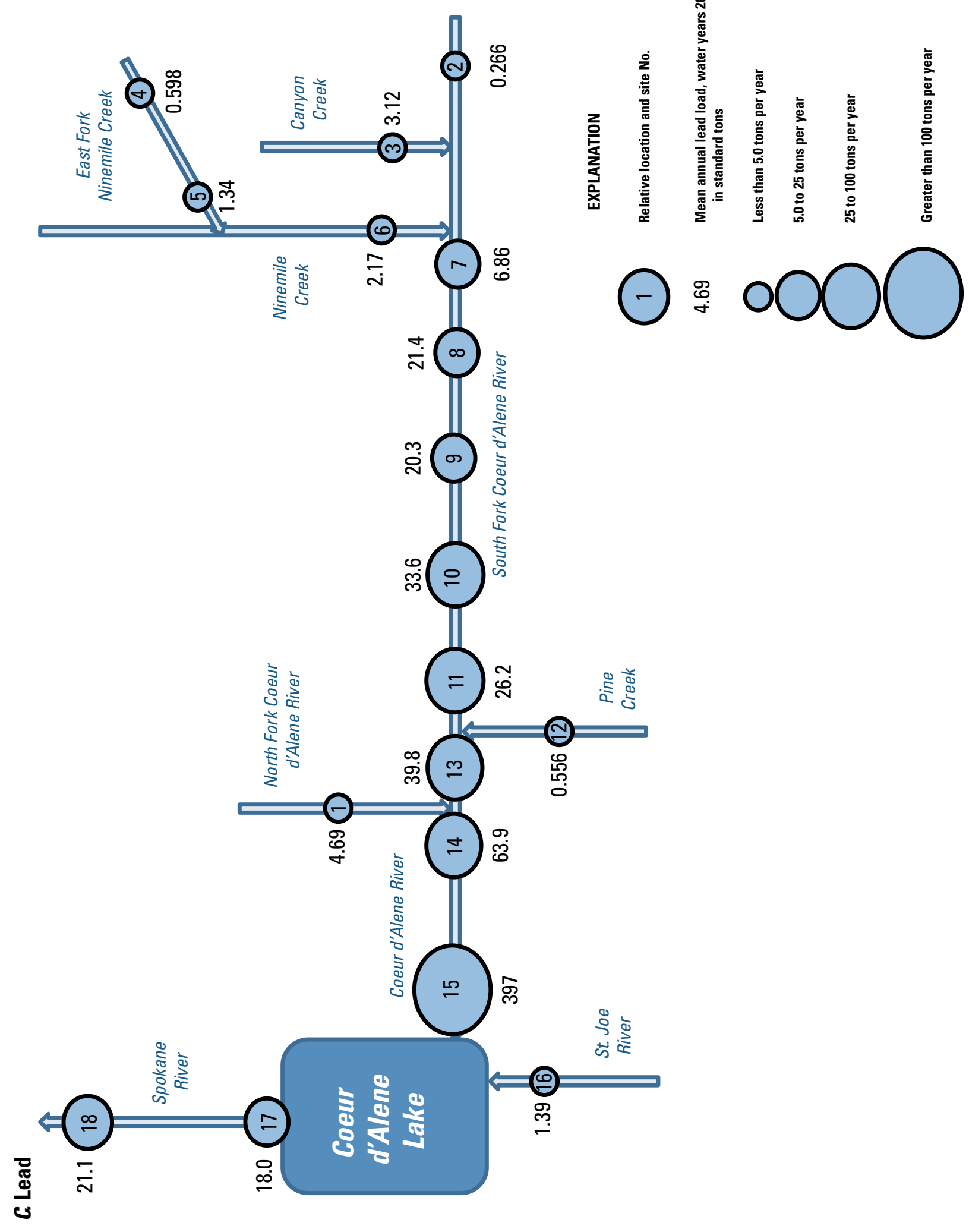




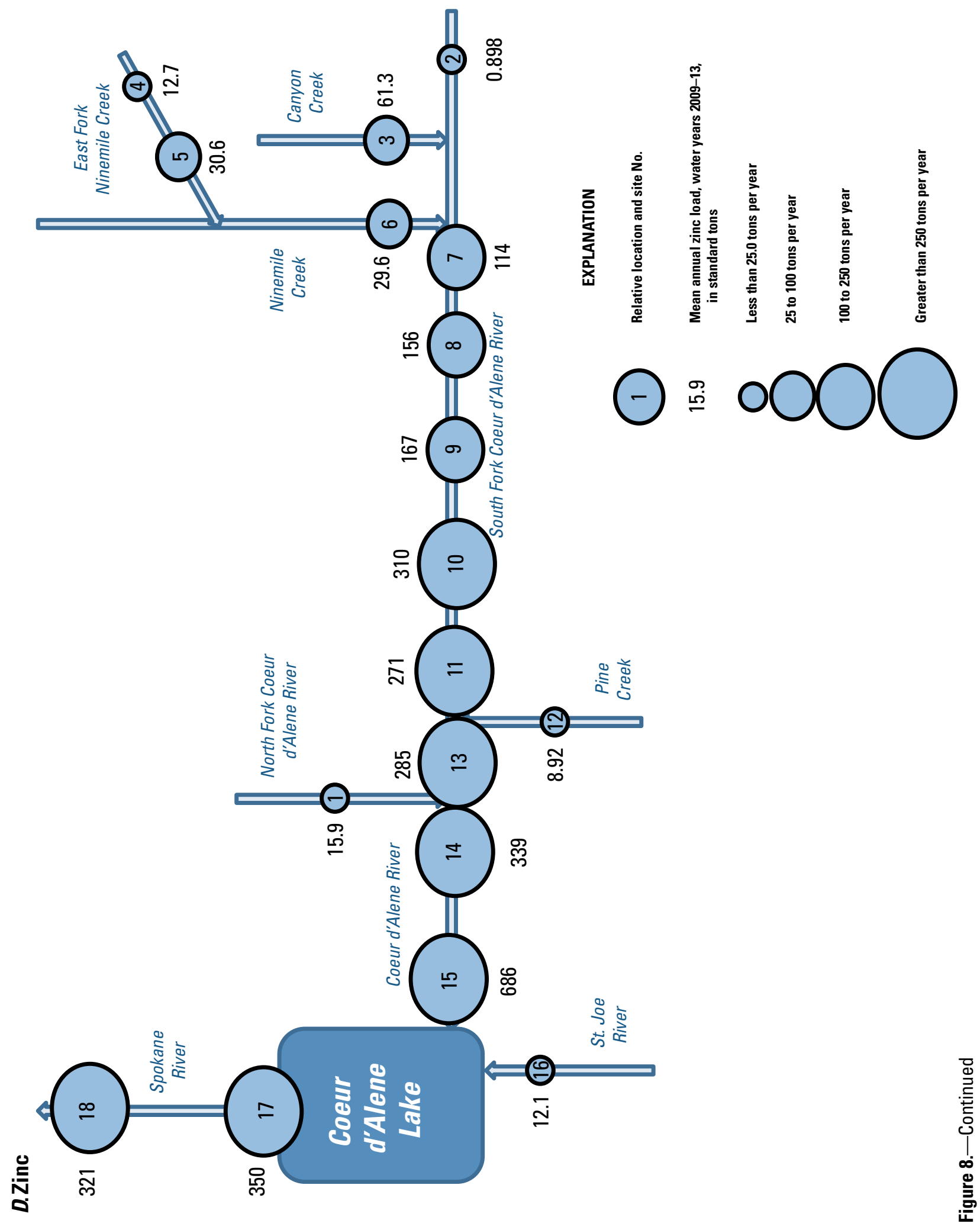


Unmeasured sources along the SFCDR between Wallace (site 7) and Elizabeth Park (site 8) contributed means of $184 \mathrm{ft}^{3} / \mathrm{s}$ of streamflow and about $0.35 \mathrm{ton} / \mathrm{yr}$ of total cadmium, $14.5 \mathrm{ton} / \mathrm{yr}$ of total lead, and $42 \mathrm{ton} / \mathrm{yr}$ of total zinc during water years 2009-13. The estimated concentrations of total cadmium, lead, and zinc in unmeasured sources between Wallace (site 7) and Elizabeth Park (site 8) were about 2.0, 80 , and $230 \mu \mathrm{g} / \mathrm{L}$, respectively. These unmeasured sources entering the SFCDR include numerous small tributaries and groundwater discharge to the SFCDR. A groundwater seepage study done during base flow conditions along the SFCDR between Wallace (site 7) and Elizabeth Park (site 8), indicated that groundwater contributed about 1 and $220 \mathrm{lb} / \mathrm{d}$ of cadmium and zinc, respectively, to the SFCDR (Barton, 2002). This groundwater discharge to the SFCDR, if extrapolated over an entire year, would account for about 0.18 ton of cadmium and about 40 tons of zinc, or about 51 and 95 percent, respectively, of the mean annual unmeasured load accrued between Wallace and Elizabeth Park during WYs 2009-13. Although the estimates for WYs 2009-13 indicate a mean annual gain of $14.5 \mathrm{ton} / \mathrm{yr}$ of total lead from unmeasured sources between Wallace and Elizabeth Park (table 8), the study by Barton (2002) documented no significant contribution of lead from groundwater in this reach.

From the SFCDR at Kellogg (site 9) downstream to Smelterville (site 10), the SFCDR gained about $33 \mathrm{ft}^{3} / \mathrm{s}$ of streamflow (table 4 , fig. 8A), 1.39 ton/yr of total cadmium, $13.3 \mathrm{ton} / \mathrm{yr}$ of total lead, and $143 \mathrm{ton} / \mathrm{yr}$ of total zinc (table 8, figs. $8 B-\underline{D}$ ). This reach of the SFCDR is bordered by the CIA and Bunker Hill Superfund site. Several small tributaries drain the area near the CIA and ultimately discharge to the SFCDR. However, streamflow and dissolved trace metals also are discharged to the SFCDR from an alluvial aquifer underlying the CIA. Water-quality samples collected during WYs 2009-13 from groundwater seeps discharging from the alluvial aquifer to the SFCDR between Kellogg (site 9) and Smelterville (site 10) have contained concentrations of dissolved cadmium and dissolved zinc greater than 100 and $10,000 \mu \mathrm{g} / \mathrm{L}$, respectively (U.S. Environmental Protection Agency, 2014). Overall, unaccounted inflows to the SFCDR between Kellogg (site 9) and Smelterville (site 10) had mean concentrations of $42.3 \mu \mathrm{g} / \mathrm{L}$ of cadmium, $409 \mu \mathrm{g} / \mathrm{L}$ of lead, and $4,400 \mu \mathrm{g} / \mathrm{L}$ of zinc. Barton (2002) estimated that during 1999 base flow conditions, groundwater discharged about $1.7 \mathrm{lb} / \mathrm{d}$ of dissolved cadmium and $560 \mathrm{lb} / \mathrm{d}$ of dissolved zinc to the SFCDR between Kellogg and Smelterville. If extrapolated over an entire year, this would equate to about $0.31 \mathrm{ton} / \mathrm{yr}$ of cadmium and $102 \mathrm{ton} / \mathrm{yr}$ of zinc, or about 22 and 71 percent, respectively, of the mean annual load accrued during WYs 2009-13 in the SFCDR between Kellogg and Smelterville.

In the reach of the SFCDR between Smelterville (site 10) and Pinehurst (site 13), most of the gain in streamflow is attributable to the inflow from Pine Creek (site 12) (fig. 8A).
Although the estimates in table 8 indicate a net gain in the total load of lead in the SFCDR between Smelterville (site 10) and Pinehurst (site 13), and a net loss in the total loads of cadmium and zinc, the differences in load between the 2 sites are small, and within the 95-percent confidence interval of the load estimates (table 8).

Load estimates of TP and TN indicate steady accrual during WYs 2009-13 in the SFCDR from Wallace (site 7) downstream to Pinehurst (site 13) (table 5; figs. 9A, and $9 B$ ). Most of the increase in TN and TP load along the SFCDR probably is attributable to discharge of wastewater treatment effluent. Using point-source data based on National Pollutant Discharge Elimination System permitting, Maupin and Ivahnenko (2011) estimated that in 2002, wastewater from the cities of Mullan, Kellogg, and Smelterville contributed about 56 tons of TN and 10 tons of TP to the SFCDR between Wallace and Pinehurst. Excluding TN and TP loading from Pine Creek (site 12), wastewater contributions from Mullan, Kellogg, and Smelterville alone account for about 43 and 64 percent, respectively, of the unmeasured TP and TN accrued annually in the SFCDR between Wallace (site 7) and Pinehurst (site 13).

\section{Coeur d'Alene River}

The Coeur d'Alene River, downstream of the confluence of the NFCDR and SFCDR, is free flowing in its upper reach; however, the overall gradient of the river is low averaging about 0.019 percent from Cataldo downstream to Harrison (Bender, 1991). The low river gradient combined with backwater from Coeur d'Alene Lake creates low river velocities in the lower CDR and throughout much of the lower part of the CDR valley. The low-velocity conditions have resulted in deposition of trace element-contaminated sediments of varying thickness derived from the mixing of tailings and mining-related wastes with uncontaminated materials. Sediments containing at least 1,000 parts per million of lead, or more than 30 times background concentrations, may cover as much as 75 percent of the CDR flood plain, from the confluence of the North and South Forks of the CDR to the CDR mouth at Coeur d'Alene Lake (Bookstrom and others, 2001).

Combined, the NFCDR (site 1) and SFCDR (site 13) discharged estimated mean loads of about 2.17, 44.5, and 301 ton/yr of total cadmium, lead, and zinc, respectively, to the Coeur d'Alene River during WYs 2009-13 (table 8; figs. $8 B-\underline{D}$ ). These totals account for about 85 percent of the combined load in the CDR near Cataldo (site 14). The SFCDR accounted for about 95,89 , and 95 percent of the cadmium, lead, and zinc loads, respectively. From the Coeur d'Alene River near Cataldo (site 14) downstream $32 \mathrm{mi}$ to the Coeur d'Alene River near Harrison (site 15), unmeasured sources contributed means of about $310 \mathrm{ft}^{3} / \mathrm{s}$ of streamflow, $2.16 \mathrm{ton} / \mathrm{yr}$ of total cadmium, $333 \mathrm{ton} / \mathrm{yr}$ of total lead, and 347 ton/yr of total zinc to the Coeur d'Alene River. 


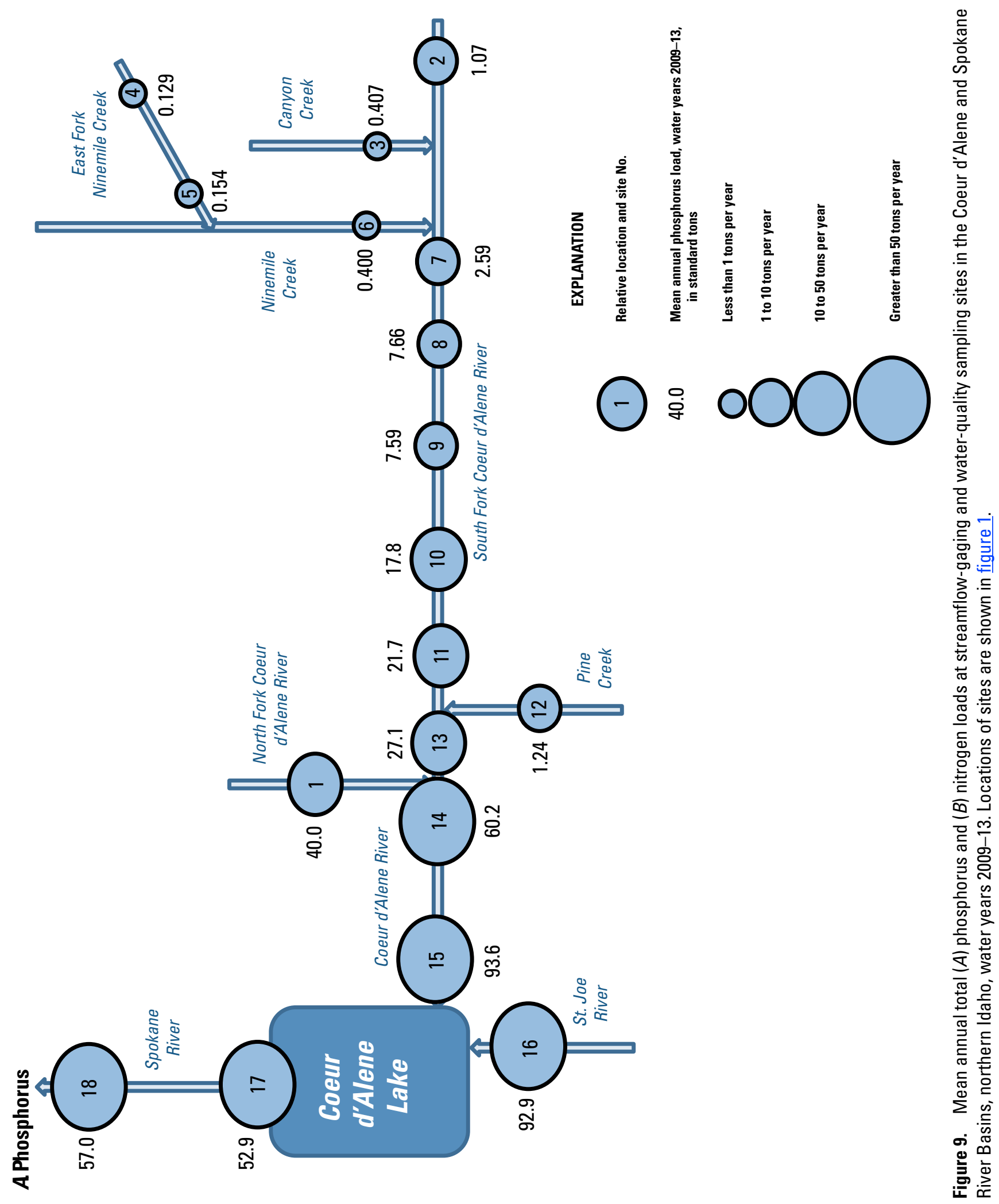




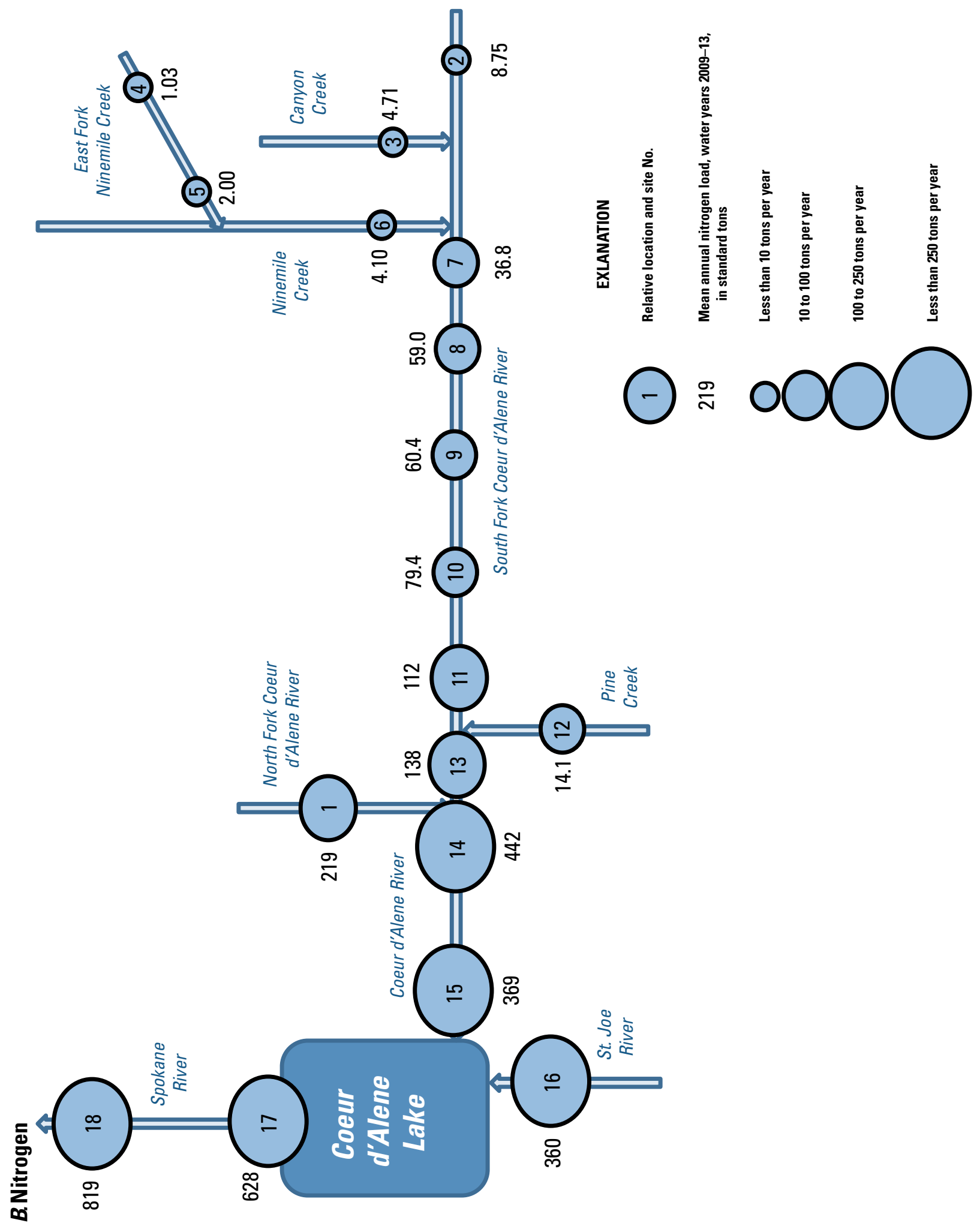

D. 
The hydrologic processes that seem to account for most of the unmeasured trace-metal load entering the Coeur d'Alene River between Cataldo and Harrison are erosion and transport of sediment-bound trace metals contained in the river channel and banks. In the CDR near Cataldo (site 14), the particulate fraction of the cadmium and zinc load accounted for only 21 and 5 percent, respectively, of the total load. In the CDR near Harrison (site 15), the particulate fraction accounted for 48 percent of the cadmium and 33 percent of the zinc. At streamflows of about $3,000 \mathrm{ft}^{3} / \mathrm{s}$ or less, dissolved and total concentrations of cadmium and zinc in the CDR near
Harrison are essentially the same (fig. 10). However, when the streamflow exceeds about $3,000 \mathrm{ft}^{3} / \mathrm{s}$, the particulate fraction of cadmium and zinc constitutes an increasingly larger proportion of the total concentration. During WYs 2009-13, about 77, 93, and 74 percent of total cadmium, lead, and zinc loads, respectively, were discharged to Coeur d'Alene Lake when the mean daily streamflow in the Coeur d'Alene River (as measured at site 15 near Harrison) exceeded 3,000 ft $3 / \mathrm{s}$, even though those exceedances occurred only 30 percent of the time during that period.

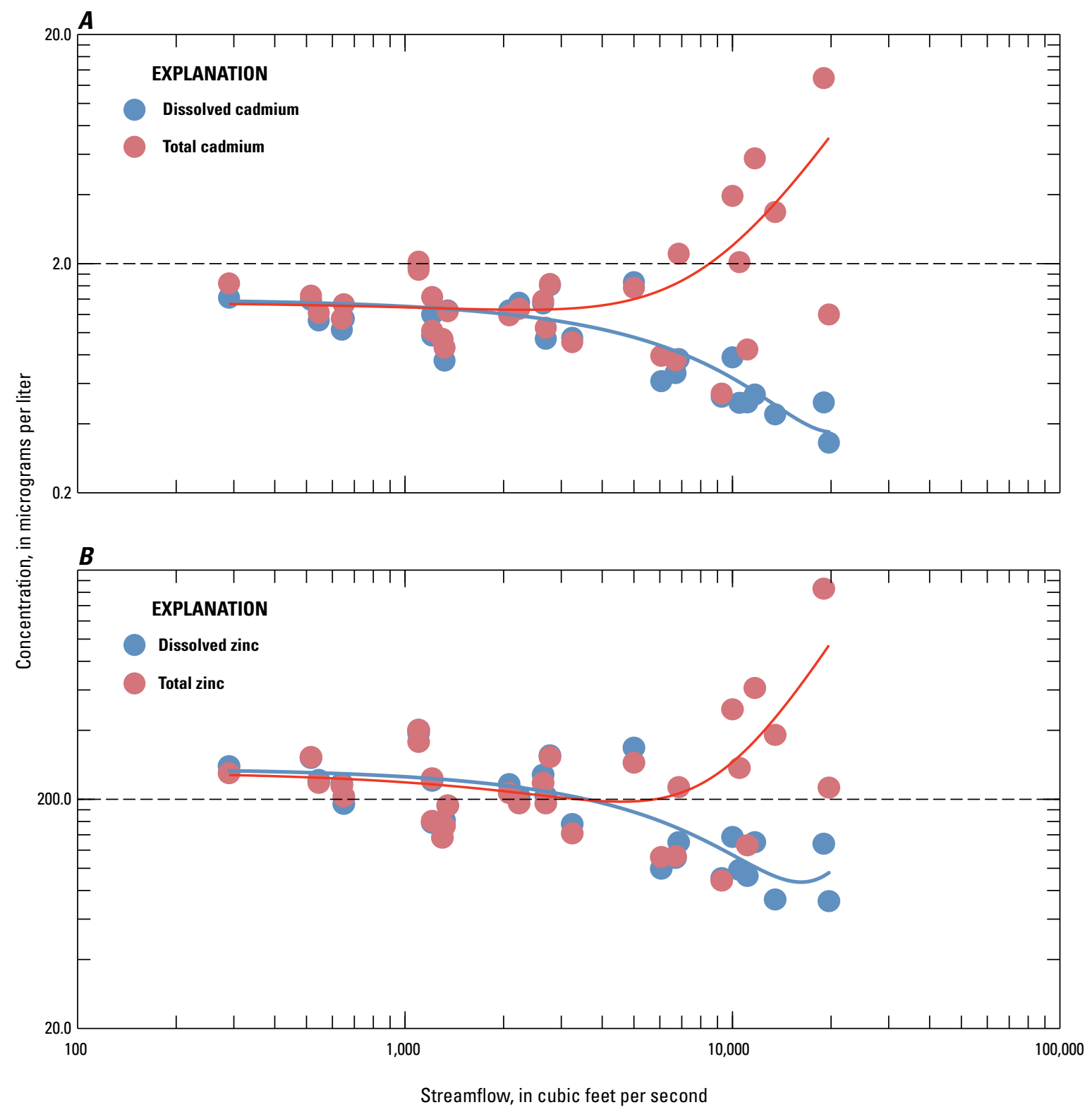

Figure 10. Relation of dissolved and total $(A)$ cadmium and $(B)$ zinc in the Coeur d'Alene River near Harrison, Idaho (site 15), water years 2009-13. 
The importance of streamflow to the overall transport of trace metals in the CDR is apparent when examining the difference in load during low and high streamflow years. In general, streamflows throughout the CDR basin during WY 2010 were less than the 25-year mean streamflows during WYs 1989-13 (fig. 4). In contrast, during WY 2011, streamflows were generally more than the 25-year mean streamflows (fig. 4). For instance, the mean annual streamflow in the CDR near Harrison (site 15) was only 1,950 $\mathrm{ft}^{3} / \mathrm{s}$ during WY 2010, whereas during 2011, the mean annual streamflow at Harrison was $4,130 \mathrm{ft}^{3} / \mathrm{s}$, more than twice the mean annual streamflow in 2010. The load of total cadmium discharged to the lake from the CDR, as measured at the Harrison site, was about 2.52 tons in WY 2010 as compared to 7.29 tons in WY 2011, or 2.9 times larger in 2011 (table 8). For total lead, the difference in load between WYs 2010 and 2011 was more marked: about 93.7 tons in WY 2010 and about 773 tons in WY 2011, more than 8 times larger. The load for total zinc was about 398 tons in WY 2010 and about 1,060 tons in WY 2011, about 2.7 times larger in WY 2011. The increase in load during higher streamflow years primarily is attributable to the cadmium, lead, and zinc associated with the particulate fraction of the water sample ( $>0.45 \mu \mathrm{m}$ diameter). During WY 2010, the particulates accounted for about 25, 84, and 12 percent of the total cadmium, lead, and zinc load, respectively, in the CDR near Harrison (site 15). During WY 2011, the relative proportion of particulate to dissolved material increased greatly, with the particulate fraction accounting for 57, 94, and 43 percent of the total cadmium, lead, and zinc loads, respectively, in the CDR near Harrison.

Winter and early spring high-streamflow events are especially important in transporting particulate cadmium, lead, and zinc in the lower CDR. Only during large streamflows $\left(>10,000 \mathrm{ft}^{3} / \mathrm{s}\right)$ does the concentration of total cadmium exceed about $3 \mu \mathrm{g} / \mathrm{L}$ and the concentration of zinc exceed about $400 \mu \mathrm{g} / \mathrm{L}$ in the CDR near Harrison (fig. 11). The total lead concentration was as much as two orders of magnitude larger at streamflows of greater than $10,000 \mathrm{ft}^{3} / \mathrm{s}$. Two rain-on-snow events that occurred in the CDR Basin during WY 2011 show the influence of high streamflow on trace-metal transport. On December 14, 2010, a sample was collected from the CDR near Harrison (site 15) at a streamflow of about $12,000 \mathrm{ft}^{3} / \mathrm{s}$ with concentrations of total cadmium, lead, and zinc of 5.8, 1,240, and $612 \mu \mathrm{g} / \mathrm{L}$, respectively (fig. 12). About 1 month later, on January 18, 2011, samples were collected during a second high flow at the Harrison site at a streamflow of about $19,000 \mathrm{ft}^{3} / \mathrm{s}$ with concentrations of cadmium, lead, and zinc of $13,3,480$, and $1,660 \mu \mathrm{g} / \mathrm{L}$, respectively. Assuming that trace-metal concentrations and streamflows remained consistent during the day of sampling, the combined discharge from the CDR during those 2 days was about 0.84 tons of cadmium, 218 tons of lead, and 104 tons of zinc to Coeur d'Alene Lake. These 2-day totals would account for about 18,55 , and 15 percent, respectively, of the loads of cadmium, lead, and zinc discharged to the lake from the CDR on a mean annual basis during WYs 2009-13.

Not all large streamflows, however, result in excessively large concentrations and loads of trace metals in the CDR. Based on the data collected during WYs 2009-13, concentrations of trace metals in the CDR during late spring snowmelt runoff typically are less than concentrations during early season rain-on-snow events. For instance, concentrations of cadmium, lead, and zinc in a sample collected near Harrison (site 15) at about 20,000 ft $3 / \mathrm{s}$ in late April 2012 were significantly less than concentrations in the samples collected during the winter streamflows in WY 2011 (fig. 12). It seems that winter and early spring high-streamflows in the CDR could be more important than spring snowmelt runoff in transporting sediment and associated trace metals into Coeur d'Alene Lake. Each year, sediments and associated trace metals accumulated and stored during the previous year are scoured and flushed from the river bottom during early, high-streamflow events of the following year. Snowmelt-runoff periods later in spring do not seem to scour and transport the same quantity of sediment and trace metals to the lake.

\section{Coeur d'Alene Lake and Spokane River}

On the basis of load estimates in the CDR near Harrison (site 15) and the St. Joe River near St. Maries (site 16), Coeur d'Alene Lake received estimated mean loads of about $4.70 \mathrm{ton} / \mathrm{yr}$ of total cadmium, $398 \mathrm{ton} / \mathrm{yr}$ of total lead, and 698 ton/yr of total zinc during WYs 2009-13, a combined load of about 1,100 ton/yr (table 8 , figs. $8 B-\underline{D}$ ). Although the CDR contributed about 47 percent of the mean annual streamflow to the lake, it contributed about 99 percent of the combined cadmium, lead, and zinc load (table 8). The loads transported out of Coeur d'Alene Lake to the Spokane River, as measured in the Spokane River at the lake outlet (site 17), indicate that the lake retained a large part of the trace-metal load that it received. Of the total cadmium, lead, and zinc load entering the lake annually, only about one-third, or about 370 tons, were transported from the lake to the Spokane River. Based on sediment cores collected in 1990, Horowitz and others (1995) estimated that about 82.5 million tons of trace-metalenriched sediments had been deposited in Coeur d'Alene Lake covering about 85 percent of lakebed. The lake seems especially efficient at trapping lead, which generally is associated with sediment particles. Of the approximately 398 ton/yr of lead entering the lake during WYs 2009-13, only about 18 ton/yr, or less than 5 percent, was transported from the lake into the Spokane River (fig. 8C). Using historical information, Bookstrom and others (2001) estimated that about 300,000 tons of elemental lead is present in the sediments on the lake bottom. 


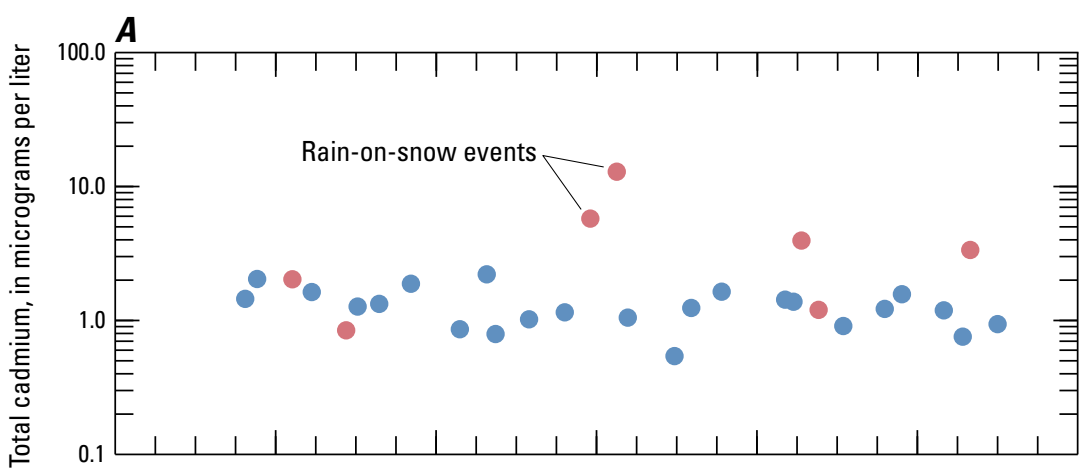

EXPLANATION
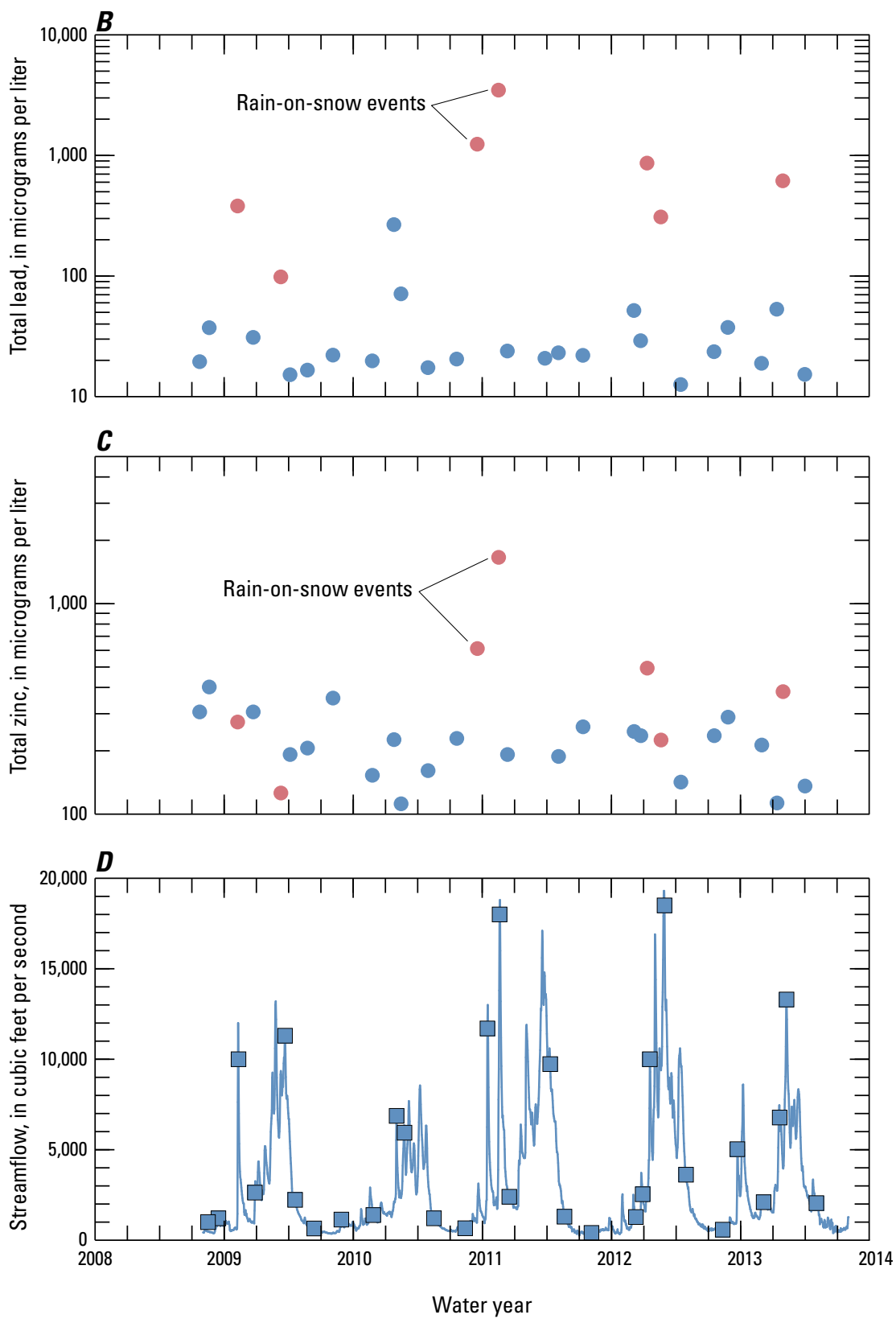

Figure 11. Concentrations of total $(A)$ cadmium, $(B)$ lead, and $(C)$ zinc (differentiated by samples collected at streamflows greater than and less than 10,000 cubic feet per second), and (D) streamflow, in the Coeur d'Alene River near Harrison, Idaho (site 15), water years 2009-13. 


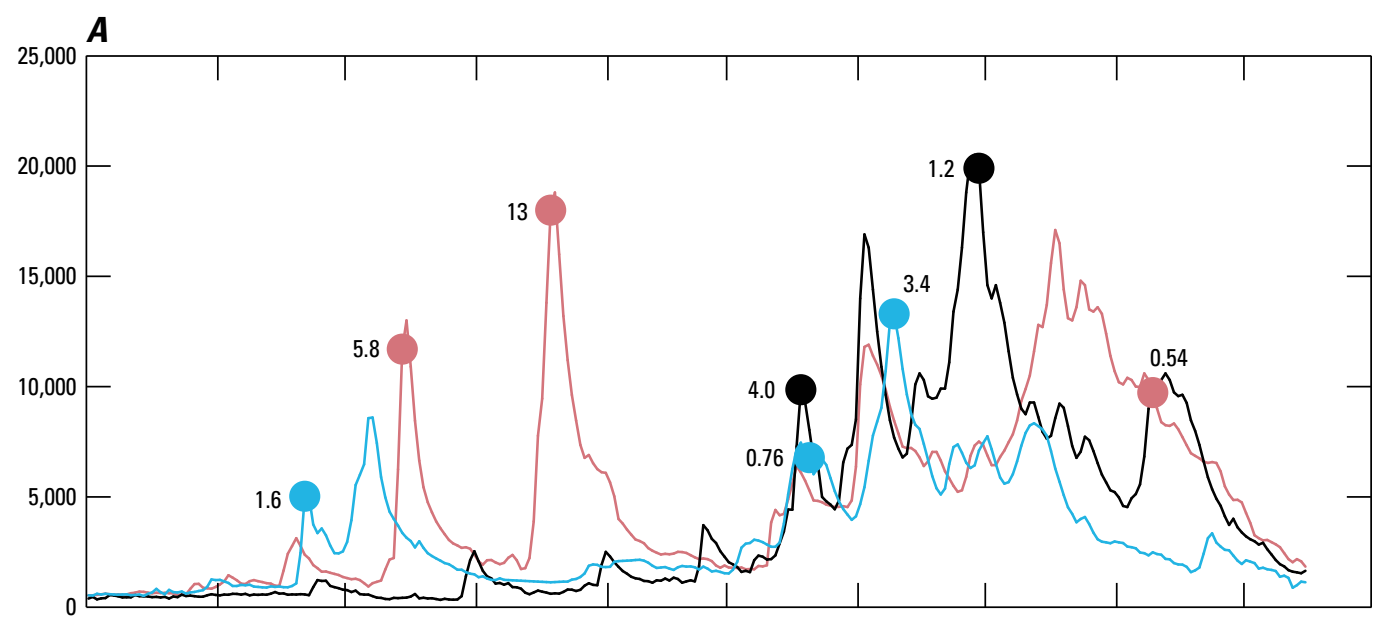

EXPLANATION

Streamflow (water year) 201

— 2012

Trace-metal samples, in micrograms per liter (water year)

2011

- 2012

2013
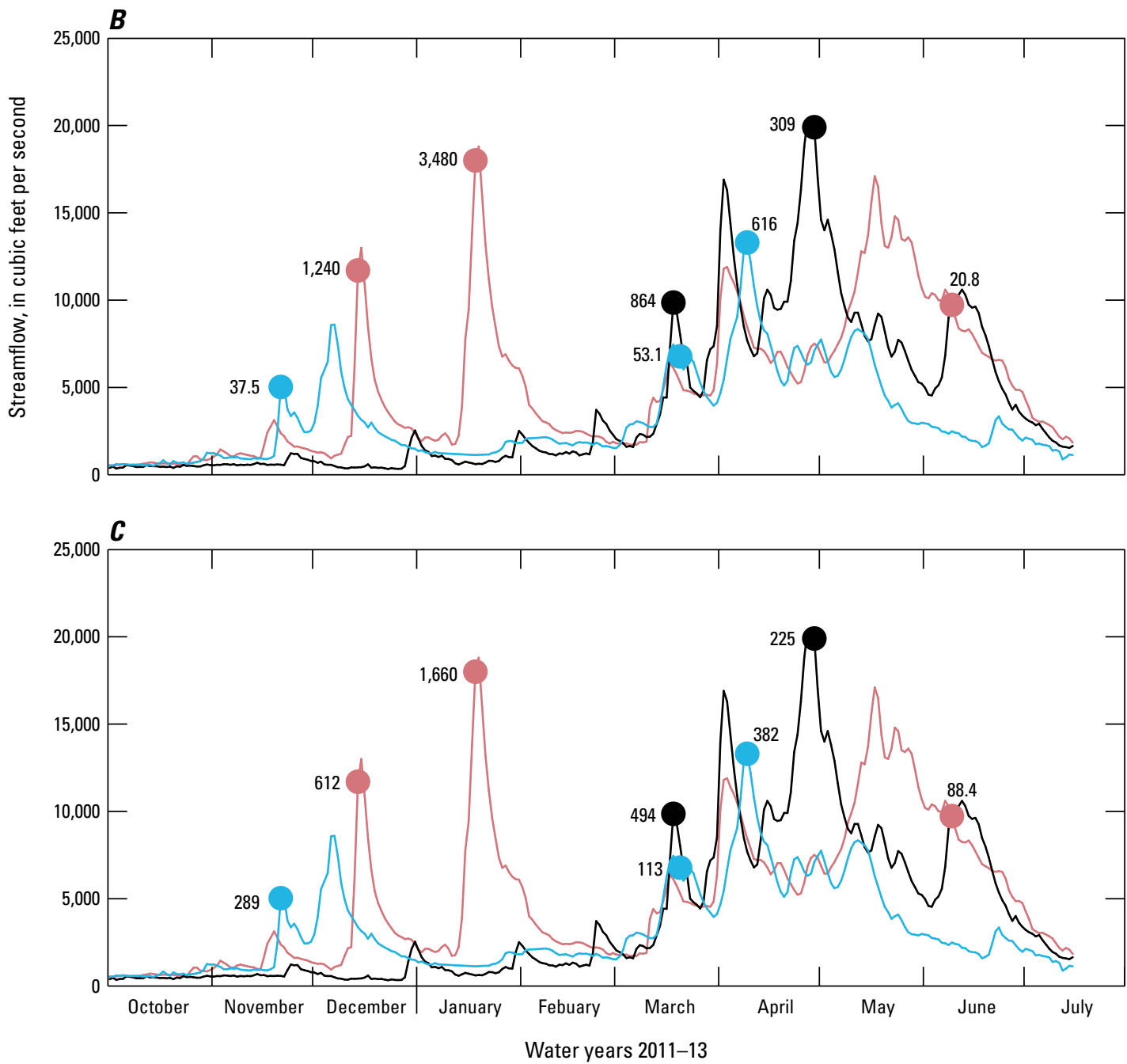

Figure 12. Concentrations of total $(A)$ cadmium, $(B)$ lead, and $(C)$ zinc in selected samples collected from the Coeur d'Alene River near Harrison, Idaho (site 15), water years 2011-13. Samples were not collected after mid-July. 
Coeur d'Alene Lake is less efficient at trapping cadmium and zinc as compared to lead. During WYs 2009-13, about $1.48 \mathrm{ton} / \mathrm{yr}$ of cadmium and $350 \mathrm{ton} / \mathrm{yr}$ of zinc, or about 32 and 50 percent of the loads entering the lake, respectively, were transported from the lake into the Spokane River (figs. $8 B, \underline{8 D}$ ). Of the trace-metal load exiting Coeur d'Alene Lake in the Spokane River at Coeur d'Alene (site 17), about 90 percent of the cadmium, 26 percent of the lead, and 100 percent of the zinc was dissolved (table 8).

Between the Spokane River at Coeur d'Alene (site 17), and the Spokane River near Post Falls (site 18), there was a negligible increase in the load of cadmium (about $0.06 \mathrm{ton} / \mathrm{yr}$ ) and a small increase in the load of lead (about 3.1 ton/yr) (table 8; figs. 8B, $\underline{8 \mathrm{C}}$ ). In contrast, there was a loss of about $29 \mathrm{ton} / \mathrm{yr}$ in the load of zinc (table 8 and fig. 8D). In this reach of the Spokane River, the river loses streamflow through seepage to the underlying Spokane Valley-Rathdrum Prairie alluvial aquifer (Bolke and Vaccaro, 1981; Gearhart and Buchanan, 2000). Seepage from the Spokane River to the underlying aquifer transports dissolved trace metals (primarily zinc, and, to a lesser extent, cadmium) to the aquifer as far as $200 \mathrm{ft}$ from the margin of the river (Marti and Garrigues, 2001; Caldwell and Bowers, 2003). Streamflow loss in this reach of the Spokane River probably accounts for most of the loss in zinc load between sites 17 and 18 (fig. 8D). The small increase in the lead load between the lake outlet (site 17) and Post Falls (site 18) probably is attributable to mobilization and transport of sediment-bound lead deposited within the channel of the Spokane River. Concentrations of lead exceeding 1,000 parts per million have been documented in samples collected from the Spokane River near Post Falls (Grosbois and others, 2001). Lead in the sediments collected from the Spokane River probably can be attributed to high-streamflow events in the CDR Basin that can scour and transport large quantities of sediment-bound lead through Coeur d'Alene Lake and into the Spokane River (Grosbois and others, 2001). Studies conducted in the Spokane River indicate that trace metals may be deposited in streambed sediment during low streamflow and remobilized and transported downstream during large streamflow events (Box and others, 2005). Mean loads of about $1.54 \mathrm{ton} / \mathrm{yr}$ of total cadmium, $21.1 \mathrm{ton} / \mathrm{yr}$ of total lead, and 321 ton/yr of total zinc were transported in the Spokane River near Post Falls (site 18) during WYs 2009-13 (figs. $8 B-\underline{D}$ ).

In contrast to trace metals, the Coeur d'Alene and St. Joe Rivers discharged nearly equivalent loads of TP and TN to Coeur d'Alene Lake during WYs 2009-13 (figs. 9A, $\underline{9 B}$ ). Combined, the Coeur d'Alene and St. Joe Rivers, as measured at Harrison and St. Maries (sites 15 and 16), discharged about 186 ton/yr of TP and 729 ton/yr of TN to Coeur d'Alene Lake. Loads of TP and TN discharged from Coeur d'Alene Lake to the Spokane River, as measured at the lake outlet (site 17), had means of about 52.9 and 628 ton/yr, respectively (figs. $9 A, 9 B$ ). Thus, on average, the lake retained about 72 percent of the TP and only about 14 percent of the TN entering the lake annually during WYs 2009-13 from the Coeur d'Alene and St Joe Rivers. Limiting the quantity of TP and TN entering Coeur d'Alene Lake is a primary concern for local stakeholders in order to protect the lake water-quality conditions. Nutrients, including TP and TN, are primary factors controlling the growth of nuisance aquatic plants that can lead to eutrophication, which in turn may influence the solubility of mining-related metals contained in lake sediments (Idaho Department of Environmental Quality and Coeur d'Alene Tribe, 2009).

\section{Long-Term Trends}

Remedial activities to remove contaminated spoil material and to stabilize banks from erosion have occurred in large areas of the SFCDR valley and its tributaries (U.S. Environmental Protection Agency, 2012). The presence and rate of change in trace-metal concentrations in response to remedial actions in the CDR Basin can be assessed by examining historical data for trends over selected periods of interest. Only four sites had sufficient cadmium, lead, and zinc data to examine trends for the time period encompassing all, or even most of WYs 1990-2013. These four sites (the SFCDR near Elizabeth Park [site 8], the SFCDR near Pinehurst [site 13], the CDR near Harrison [site 15], and the Spokane River near Post Falls [site 18]) represent key locations in the Coeur d'Alene and Spokane River Basins.

The SFCDR near Elizabeth Park (site 8) drains most of the upper part of the SFCDR valley and captures drainage from Canyon Creek, Ninemile Creek, and other historically mined tributaries. Although some groundwater discharges to the SFCDR upstream of Elizabeth Park, the cadmiumand zinc-laden groundwater discharging from the alluvium underlying the CIA occurs just downstream of Elizabeth Park between the towns of Kellogg and Pinehurst (fig. 1). The SFCDR near Pinehurst (site 13) is downstream of the CIA and integrates the water quality from the entire SFCDR Basin. The CDR near Harrison (site 15) integrates the entire CDR Basin including the relatively unaffected NFCDR and the SFCDR as well as the main stem of the CDR between Cataldo and Harrison. The Spokane River near Post Falls (site 18) represents the water quality downstream of Coeur d'Alene Lake.

Remediation efforts in tributaries to the SFCDR and along the river corridor seem to have resulted in large decreases in the trace-metal concentrations throughout the Coeur d'Alene and Spokane River Basins. From the early 1990s to 2013, the concentrations of total lead and total zinc showed a significant decrease $(p<0.05)$ at all four sites evaluated using the Seasonal Kendall trend test (table 6). 
Table 6. Results from Seasonal Kendall trend tests on concentrations of total cadmium, lead, and zinc, and chronic Ambient Water Quality Criteria ratios for dissolved cadmium and zinc at selected streamflow-gaging and water-quality sampling sites in the Coeur d'Alene and Spokane River Basins, northern Idaho, water years 1990-2013.

[Locations of sites are shown in figure 1. Bolded and italicized slopes and p-values indicate a significant trend at 95-percent confidence interval. Abbreviations: $(\mu \mathrm{g} / \mathrm{L}) / \mathrm{yr}$, microgram per liter per year; units/yr, ratio of dissolved constituent concentration to chronic Ambient Water Quality Criteria (AWQC); SFCDR, South Fork Coeur d'Alene River; CDR, Coeur d'Alene River; ID, Idaho]

\begin{tabular}{|c|c|c|c|c|c|}
\hline \multirow{2}{*}{$\begin{array}{l}\text { Site } \\
\text { No. }\end{array}$} & \multirow[b]{2}{*}{ Streamgage name } & \multicolumn{4}{|c|}{ Cadmium } \\
\hline & & $\begin{array}{l}\text { Period of analysis } \\
\text { (water years) }\end{array}$ & $\begin{array}{c}\text { tau correlation } \\
\text { coefficient }\end{array}$ & $\begin{array}{c}\text { Slope } \\
{[(\mu \mathrm{g} / \mathrm{L}) / \mathrm{yr}]}\end{array}$ & p-value \\
\hline 8 & SFCDR at Elizabeth Park near Kellogg ID & $1993-2013$ & -0.65 & -0.18 & $<0.001$ \\
\hline 13 & SFCDR near Pinehurst ID & $1992-2013$ & -0.59 & -0.25 & $<0.001$ \\
\hline 15 & CDR near Harrison ID & $1991-2013$ & -0.44 & -0.06 & $<0.001$ \\
\hline 8 & SFCDR at Elizabeth Park near Kellogg ID & $2003-2013$ & -0.46 & -0.16 & $<0.001$ \\
\hline 13 & SFCDR near Pinehurst ID & $2003-2013$ & -0.11 & -0.032 & 0.392 \\
\hline 15 & CDR near Harrison ID & $2003-2013$ & -0.01 & -0.002 & 0.967 \\
\hline 18 & Spokane River near Post Falls ID & 2003-2013 & -0.03 & -0.001 & 1.000 \\
\hline \multirow{2}{*}{$\begin{array}{l}\text { Site } \\
\text { No. }\end{array}$} & \multirow[b]{2}{*}{ Streamgage name } & \multicolumn{4}{|c|}{ Lead } \\
\hline & & $\begin{array}{l}\text { Period of analysis } \\
\text { (water years) }\end{array}$ & $\begin{array}{c}\text { tau correlation } \\
\text { coefficient }\end{array}$ & $\begin{array}{c}\text { Slope } \\
{[(\mu \mathrm{g} / \mathrm{L}) / \mathrm{yr}]}\end{array}$ & p-value \\
\hline 8 & SFCDR at Elizabeth Park near Kellogg ID & $1993-2013$ & -0.41 & -0.71 & $<0.001$ \\
\hline 13 & SFCDR near Pinehurst ID & $1992-2013$ & -0.48 & -1.3 & $<0.001$ \\
\hline 15 & CDR near Harrison ID & $1991-2013$ & -0.23 & -0.57 & 0.004 \\
\hline 18 & Spokane River near Post Falls ID & $1991-2013$ & -0.36 & -0.09 & 0.002 \\
\hline 8 & SFCDR at Elizabeth Park near Kellogg ID & $2003-2013$ & -0.19 & -0.25 & 0.124 \\
\hline 13 & SFCDR near Pinehurst ID & $2003-2013$ & -0.10 & -0.22 & 0.442 \\
\hline 15 & CDR near Harrison ID & $2003-2013$ & 0.15 & 0.45 & 0.228 \\
\hline 18 & Spokane River near Post Falls ID & 2003-2013 & -0.17 & -0.02 & 0.554 \\
\hline \multirow{2}{*}{$\begin{array}{l}\text { Site } \\
\text { No. }\end{array}$} & \multirow[b]{2}{*}{ Streamgage name } & \multicolumn{4}{|c|}{ Zinc } \\
\hline & & $\begin{array}{l}\text { Period of analysis } \\
\text { (water years) }\end{array}$ & $\begin{array}{c}\text { tau correlation } \\
\text { coefficient }\end{array}$ & $\begin{array}{c}\text { Slope } \\
[(\mu \mathrm{g} / \mathrm{L}) / \mathrm{yr}])\end{array}$ & p-value \\
\hline 8 & SFCDR at Elizabeth Park near Kellogg ID & $1993-2013$ & -0.58 & -24 & $<0.001$ \\
\hline 13 & SFCDR near Pinehurst ID & $1992-2013$ & -0.66 & -45 & $<0.001$ \\
\hline 15 & CDR near Harrison ID & $1991-2013$ & -0.44 & -8.4 & $<0.001$ \\
\hline 18 & Spokane River near Post Falls ID & $1991-2013$ & -0.70 & -2.3 & $<0.001$ \\
\hline 8 & SFCDR at Elizabeth Park near Kellogg ID & $2003-2013$ & -0.48 & -22 & $<0.001$ \\
\hline 13 & SFCDR near Pinehurst ID & $2003-2013$ & -0.20 & -8.8 & 0.104 \\
\hline 15 & CDR near Harrison ID & $2003-2013$ & 0.09 & 1.4 & 0.480 \\
\hline 18 & Spokane River near Post Falls ID & $2003-2013$ & -0.59 & -1.6 & 0.018 \\
\hline
\end{tabular}


Table 6. Results from Seasonal Kendall trend tests on concentrations of total cadmium, lead, and zinc, and chronic Ambient Water Quality Criteria ratios for dissolved cadmium and zinc at selected streamflow-gaging and water-quality sampling sites in the Coeur d'Alene and Spokane River Basins, northern Idaho, water years 1990-2013.—Continued

[Locations of sites are shown in figure 1. Bolded and italicized slopes and p-values indicate a significant trend at 95-percent confidence interval. Abbreviations: $(\mu \mathrm{g} / \mathrm{L}) / \mathrm{yr}$, microgram per liter per year; units/yr, ratio of dissolved constituent concentration to chronic Ambient Water Quality Criteria (AWQC); SFCDR, South Fork Coeur d'Alene River; CDR, Coeur d'Alene River; ID, Idaho]

\begin{tabular}{|c|c|c|c|c|c|}
\hline \multirow{2}{*}{$\begin{array}{l}\text { Site } \\
\text { No. }\end{array}$} & \multirow[b]{2}{*}{ Streamgage name } & \multicolumn{4}{|c|}{ Chronic AWQC ratio - cadmium } \\
\hline & & $\begin{array}{c}\text { Period of analysis } \\
\text { (water years) }\end{array}$ & $\begin{array}{c}\text { tau correlation } \\
\text { coefficient }\end{array}$ & $\begin{array}{c}\text { Slope } \\
\text { (units/yr) }\end{array}$ & p-value \\
\hline 8 & SFCDR at Elizabeth Park near Kellogg ID & $1997-2013$ & -0.70 & -0.22 & $<0.001$ \\
\hline 13 & SFCDR near Pinehurst ID & $1990-2013$ & -0.53 & -0.22 & $<0.001$ \\
\hline 15 & CDR near Harrison ID & $1996-2013$ & -0.49 & -0.14 & $<0.001$ \\
\hline 8 & SFCDR at Elizabeth Park near Kellogg ID & $2003-2013$ & -0.59 & -0.25 & $<0.001$ \\
\hline 13 & SFCDR near Pinehurst ID & $2003-2013$ & -0.15 & -0.17 & 0.171 \\
\hline 15 & CDR near Harrison ID & $2003-2013$ & 0.01 & 0.001 & 0.967 \\
\hline 18 & Spokane River near Post Falls ID & $2003-2013$ & 0.40 & 0.03 & 0.034 \\
\hline \multirow{2}{*}{$\begin{array}{l}\text { Site } \\
\text { No. }\end{array}$} & \multirow[b]{2}{*}{ Streamgage name } & \multicolumn{4}{|c|}{ Chronic AWQC ratio - zinc } \\
\hline & & $\begin{array}{c}\text { Period of analysis } \\
\text { (water years) }\end{array}$ & $\begin{array}{c}\text { tau correlation } \\
\text { coefficient }\end{array}$ & $\begin{array}{c}\text { Slope } \\
\text { (units/yr) }\end{array}$ & p-value \\
\hline 8 & SFCDR at Elizabeth Park near Kellogg ID & $1997-2013$ & -0.59 & -0.14 & $<0.001$ \\
\hline 13 & SFCDR near Pinehurst ID & $1990-2013$ & -0.60 & -0.20 & $<0.001$ \\
\hline 15 & CDR near Harrison ID & $1996-2013$ & -0.51 & -0.14 & $<0.001$ \\
\hline 18 & Spokane River near Post Falls ID & $1990-2013$ & -0.60 & -0.06 & $<0.001$ \\
\hline 8 & SFCDR at Elizabeth Park near Kellogg ID & $2003-2013$ & -0.54 & -0.17 & $<0.001$ \\
\hline 13 & SFCDR near Pinehurst ID & $2003-2013$ & -0.07 & -0.04 & 0.608 \\
\hline 15 & CDR near Harrison ID & $2003-2013$ & -0.02 & -0.01 & 0.901 \\
\hline 18 & Spokane River near Post Falls ID & $2003-2013$ & 0.07 & 0.01 & 0.761 \\
\hline
\end{tabular}

Total cadmium concentrations showed a significant decrease at three of the sites. The Spokane River near Post Falls (site 18) was not trend-tested for cadmium during WYs 1990-2013 because, prior to 1999, the analytical reporting limit for total cadmium exceeded most of the environmental concentrations at the site. During 1999, the reporting limit for cadmium was lowered from 1.0 to $0.05 \mu \mathrm{g} / \mathrm{L}$ allowing for detection and quantification of cadmium at smaller environmental concentrations.

Time-series graphs and LOWESS smooths for each of the four trend sites (fig. 13A) show decreasing zinc concentrations throughout the Coeur d'Alene and Spokane River Basins. Each of the sites show a relatively consistent downward slope to the trend line (all statistically significant) through the early 2000s, followed by a slight leveling of the slope from about WYs 2003 through 2013. The rate of decrease in concentration, or the slope as listed in table 6, was largest at the SFCDR near Pinehurst (site 13) for all three trace metals. The total zinc concentration in the SFCDR near Pinehurst decreased by an average of about $45(\mu \mathrm{g} / \mathrm{L}) / \mathrm{yr}$, or about $990 \mu \mathrm{g} / \mathrm{L}$ during WYs 1992-2013. The concentrations of total lead and cadmium in the SFCDR near Pinehurst (site 13) decreased, on average, by 1.3 and $0.25(\mu \mathrm{g} / \mathrm{L}) / \mathrm{yr}$, respectively, or about 29 and $5.5 \mu \mathrm{g} / \mathrm{L}$ during WYs 1992-2013.

During WYs 2003-13, only the SFCDR near Elizabeth Park (site 8) showed a significant decrease in the concentration of total cadmium, and none of the sites showed a significant decrease in the concentration of total lead (table 6). In the SFCDR near Elizabeth Park (site 8) and near Pinehurst (site 13), the concentrations of total zinc seemed to continue decreasing and did not exceed $1,500 \mu \mathrm{g} / \mathrm{L}$ in any of the samples collected (fig. 13B). The relative consistency in the difference in zinc concentrations between Elizabeth Park and Pinehurst during WYs 2003-13 (fig. 13B) indicates a consistent source of zinc to the SFCDR between the two sites. This is most likely dissolved zinc entering the SFCDR from groundwater contributions near the CIA. However, the decrease in the zinc concentration in the SFCDR only was significant at Elizabeth Park $(p<0.001)$ and was not significant near Pinehurst $(\mathrm{p}=0.104)$. Zinc concentrations also showed a significant decrease $(\mathrm{p}=0.018)$ in the Spokane River near Post Falls (site 18), but not in the CDR near Harrison (site 15) $(\mathrm{p}=0.480)$. 


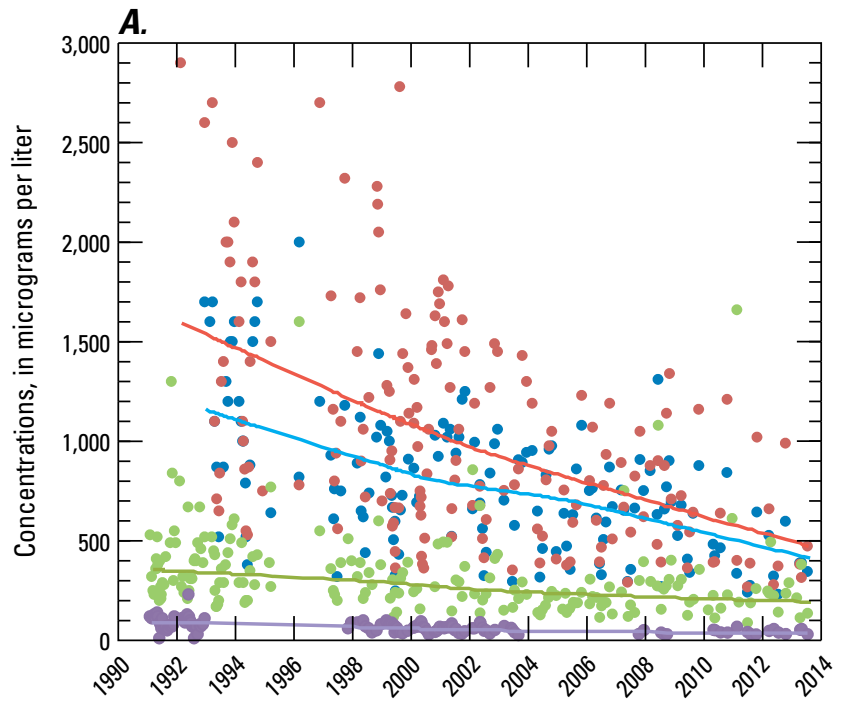

Water year

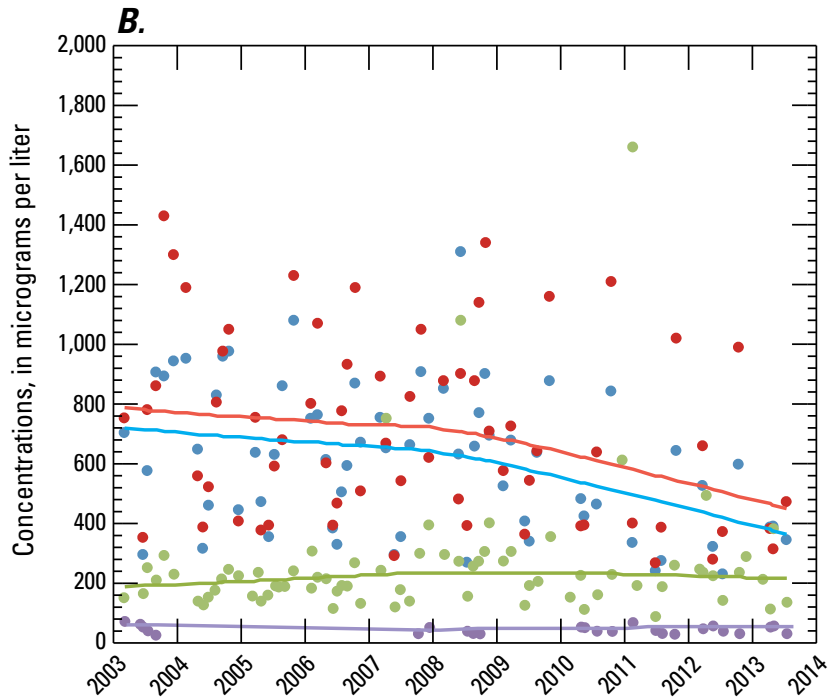

Water year

\section{EXPLANATION}

- South Fork Coeur d'Alene River near Elizabeth Park (Site 8)

- South Fork Coeur d'Alene River near Pinehurst (Site 13)

- Coeur d'Alene River near Harrison (Site 15)

- Spokane River near Post Falls (Site 18)

Figure 13. Historical trends in total zinc concentrations at selected streamflow-gaging and water-quality sampling sites in the Coeur d'Alene and Spokane River Basins, northern Idaho, water years $(A)$ 1990-2013 and (B) 2003-13.

Trend tests on chronic AWQC ratios for cadmium and zinc showed a similar result as tests for concentrations (fig. 14). At each of the four sites trend tested, the AWQC ratios for cadmium and zinc showed significant downward trends between the 1990s and WY 2013, but only in the SFCDR near Elizabeth Park (site 8) was there a significant (downward) trend during WYs 2003-13. In the Spokane River near Post Falls (site 18), there was a small, but statistically significant upward trend in the AWQC ratio for cadmium during WYs 2003-13 (table 6).

The continued significant downward trends in the concentrations of cadmium and zinc, and the AWQC ratios of cadmium and zinc in the SFCDR near Elizabeth Park (site 8), indicate that remedial efforts in the SFCDR valley and its tributaries continue to result in improved water quality conditions. However, the downstream site at Pinehurst (site 13) does not seem to have responded to recent remedial activities to the same extent as the site at Elizabeth Park. This is probably the result of groundwater discharge between the SFCDR sites at Kellogg (site 9) and Smelterville (site 10) that, along with the minor tributaries Bunker Creek and Government Gulch, provides the river with about 1.39 ton/yr of cadmium and 143 ton/yr of zinc (figs. $8 B, \underline{8 D}$ ). It seems unlikely that these downward trends in the concentrations of cadmium and zinc will be apparent in the lower SFCDR downstream of the CIA until the cadmium and zinc loads entering the SFCDR from groundwater sources near the CIA are reduced or eliminated. 

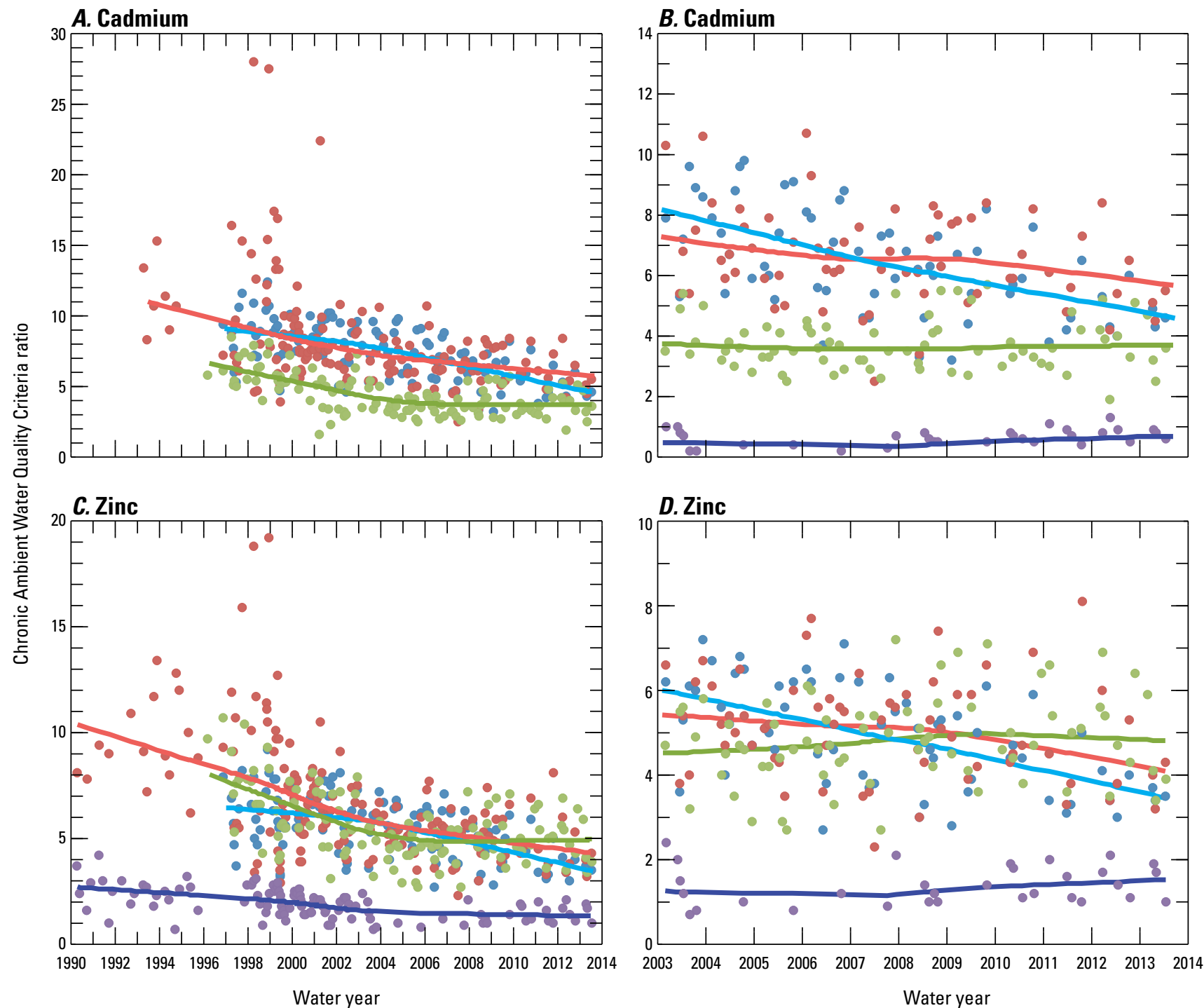

EXPLANATION

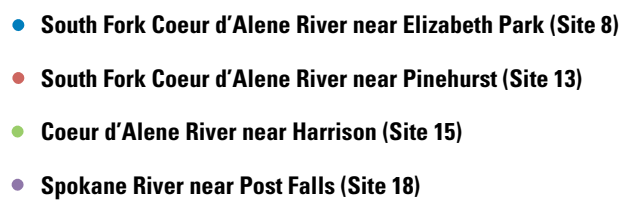

Figure 14. Historical trends in Ambient Water Quality Criteria ratios for cadmium and zinc at selected streamflow-gaging and water-quality sampling sites, Coeur d'Alene and Spokane River Basins, northern Idaho, water years 1990-2013 and $2003-13$. 


\section{Summary and Conclusions}

The evaluation of surface-water data collected as part of the Basin Environmental Monitoring Plan confirms findings from previous investigations that have identified mining activities in mineralized areas of the South Fork Coeur d'Alene River (SFCDR) Basin as the primary source of trace-metal contaminated water and sediment in the SFCDR, the Coeur d'Alene River (CDR), Coeur d'Alene Lake, and the Spokane River. The occurrence and transport of 3 trace metals of environmental concern (cadmium, lead, and zinc) and 2 nutrients (total phosphorus and nitrogen) were evaluated for water years (WYs) 2009-13 using an approach that quantified concentrations and loads at 18 streamflow-gaging and water-quality sampling sites in the Coeur d'Alene and Spokane River Basins. A Seasonal Kendall test was used to detect statistically significant temporal trends in cadmium, lead, and zinc concentrations, and Ambient Water Quality Criteria (AWQC) ratios of cadmium and zinc at four sites with long-term data in the Coeur d'Alene and Spokane River Basins.

The results indicate that, during WYs 2009-13, cadmium and zinc entering Coeur d'Alene Lake and transported downstream in the Spokane River were derived primarily from mining-affected tributaries to the SFCDR and from groundwater discharge to the SFCDR near the Central Impoundment Area (CIA). Cadmium and zinc were transported in streams predominantly in the dissolved phase (less than 0.45 micrometer), and at most sites, concentrations were inversely correlated with streamflow and varied widely over the range of streamflows sampled. In contrast to cadmium and zinc, lead was transported in streams primarily in the particulate form, and total lead concentrations were positively correlated with streamflow. Transport of lead occurred primarily during high streamflow when lead-rich sediments stored in stream channels and the flood plain of the CDR are eroded, transported, and redistributed downstream. Control of the transport of contaminated sediment through the Coeur d'Alene and Spokane River Basins is a key factor for ensuring the long-term effectiveness of remedial activities in the SFCDR and CDR.

From the SFCDR near Mullan downstream to the SFCDR near Pinehurst, the concentration of individual trace metals increased greatly; mean streamflow-weighted concentrations of total cadmium, lead, and zinc in the SFCDR near Pinehurst for WYs 2009-13 were 3.71, 61.4, and 514 micrograms per liter $(\mu \mathrm{g} / \mathrm{L})$, respectively. Major tributary sources of trace metals to the SFCDR are Canyon Creek and Ninemile Creek. Combined, these two tributaries contributed estimated mean loads of about 0.575 tons per year (ton/yr) of total cadmium, $5.29 \mathrm{ton} / \mathrm{yr}$ of total lead, and $90.9 \mathrm{ton} / \mathrm{yr}$ of total zinc to the SFCDR during WYs 2009-13. Bunker Creek, Government Gulch, and groundwater discharge near the CIA between Kellogg and Smelterville were other major sources of cadmium and zinc to the SFCDR, contributing an estimated 1.39 and 143 ton/yr, respectively, during WYs 2009-13.
Although concentrations of cadmium, lead, and zinc in streams throughout the Coeur d'Alene and Spokane River Basins have shown significant decreases since the early 1990s in response to remedial activities, the rate of decrease has slowed since 2003, especially downstream of the CIA. Additionally, significant decreases in cadmium and zinc concentrations in the lower SFCDR and CDR would require reducing the load of these trace metals being discharged to the SFCDR from groundwater near the CIA. The loading estimates from this study provide a valuable baseline for evaluating the efficacy of future remedial activities designed to reduce cadmium and zinc loading to discrete reaches of the SFCDR.

Periodic flooding in the Coeur d'Alene River Basin plays an important role in the redistribution of trace metals throughout the Coeur d'Alene and Spokane River Basins. The timing, intensity, and duration of storms is an important factor in moving sediment and sediment-bound trace metals from the SFCDR downstream to the CDR, from the CDR into Coeur d'Alene Lake, and from the lake into the Spokane River. Erosion and transport of sediment in the CDR at Cataldo downstream to Harrison results in a large increase in the load of sediment-associated trace metals entering Coeur d'Alene Lake. At Cataldo, the particulate fraction of the cadmium and zinc load in the CDR accounted for only 21 and 5 percent of the total load, respectively, whereas at Harrison the particulate fraction accounted for 48 percent of the total cadmium load and 33 percent of the total zinc load. The mean annual load of lead in the CDR near Harrison was nearly 400 tons, more than 5 times the load about $28 \mathrm{mi}$ upstream in the CDR at Cataldo.

A large part of the trace-metal load entering Coeur d'Alene Lake from the Coeur d'Alene and St. Joe Rivers is retained in the lake, most likely in sediments on the lake bottom. On an annual mean basis, Coeur d'Alene Lake received nearly 1,100 tons of cadmium, lead, and zinc combined, about 99 percent of which was delivered from the Coeur d'Alene River. Of the total trace-metal load entering the lake, about one-third, or about 370 tons per year, were transported from the lake and into the Spokane River. The mean streamflow-weighted concentrations of total cadmium, lead, and zinc in the Spokane River near Post Falls (site 18) were $0.231,2.91$, and $48.9 \mu \mathrm{g} / \mathrm{L}$, respectively, substantially smaller than the concentrations entering the lake from the Coeur d'Alene River. About 1.48 tons of total cadmium, 18 tons of total lead, and 350 tons of total zinc exited Coeur d'Alene Lake and entered the Spokane River annually during WYs 2009-13.

Because they account for toxicity effects on aquatic organisms, AWQC ratios are important benchmarks for establishing the effectiveness of remedial activities in the Coeur d'Alene and Spokane River Basins. Although long-term monitoring sites in the sampling network have shown great improvement in the chronic AWQC for cadmium and zinc since the early 1990s, the chronic AWQC was achieved only at sites on the NFCDR at Enaville, the SFCDR near Mullan, 
and the St. Joe River near St. Maries. Chronic AWQC ratios at both sites on the Spokane River generally were close to achieving benchmark values. Sites the farthest from achieving the chronic AWQC criteria were located on Canyon Creek, the East Fork of Ninemile Creek, and Ninemile Creek. The downstream site on the East Fork of Ninemile Creek had mean streamflow-weighted AWQC ratios for cadmium and zinc of 64 and 51, respectively, more than twice the ratio of any other site in the sampling network.

Concentrations and loads of total phosphorus (TP) and total nitrogen (TN) generally were low along the SFCDR between Mullan and Kellogg. Downstream of Kellogg, the mean streamflow-weighted concentrations of TP and TN in the SFCDR increased substantially in response to discharge from wastewater treatment facilities. Of all the sites in the BEMP network, mean streamflow-weighted concentrations for TP and TN (0.054 and 0.284 milligrams per liter, respectively) were highest in the SFCDR above Pine Creek near Pinehurst. The loads of TP and TN delivered from the Coeur d'Alene and St. Joe Rivers to Coeur d'Alene Lake were about equivalent, with combined averages of about 186 and 729 ton/yr, respectively, during WYs 2009-13. About 52.9 ton/yr of TP and $628 \mathrm{ton} / \mathrm{yr}$ of TN were transported out of Coeur d'Alene Lake and into the Spokane River during WYs 2009-13. The retention of TP (about 72 percent) and TN (about 14 percent) in Coeur d'Alene Lake is of concern because these nutrients potentially can stimulate aquatic growth and change the trophic status of the lake. Despite relatively oligotrophic conditions in Coeur d'Alene Lake, previous studies have documented substantial hypolimnetic dissolved-oxygen deficits, especially in the shallow southern end. Continued monitoring of lake conditions is an important consideration in determining the assimilative capacity of the lake for nutrients, and to ascertain whether anoxic conditions on the lake bottom would result in the release of previously deposited trace metals from the lakebed.

Trend results indicate that remedial efforts in the SFCDR valley and its tributaries since the early 1990s have been successful in reducing concentrations of trace metals in the SFCDR, CDR, and Spokane River. Statistically significant downward trends were noted during WYs 1990-2013 for all constituents evaluated in the SFCDR at Elizabeth Park and the SFCDR near Pinehurst, in the CDR near Harrison, and in the Spokane River near Post Falls. During WYs 2003-13, the SFCDR at Elizabeth Park continued to indicate significant downward trends in total cadmium and zinc concentrations and their AWQC ratios. Of the other three long-term sites, only the Spokane River near Post Falls showed significant trends during WYs 2003-13: a downward trend in total zinc concentration and an upward trend in the chronic AWQC ratio for dissolved cadmium. Further significant reductions in cadmium and zinc concentrations in the Spokane and Coeur d'Alene River Basins likely would necessitate reducing loads entering the SFCDR from cadmium- and zinc-enriched groundwater near the CIA.
Load models developed in this study are a valuable tool for estimating streamflow-weighted concentrations and loads of trace metals and nutrients in the Coeur d'Alene and Spokane River Basins. As additional data are collected, they can be integrated into the existing models to improve the understanding of how trace metals and nutrients are transported and deposited throughout the basins. Future data-collection activities should continue to target the hydrograph to incorporate data from a variety of streamflow conditions necessary for model development. Additionally, continued sampling at sites such as the SFCDR near Elizabeth Park, the SFCDR near Pinehurst, the Coeur d'Alene River near Harrison, and the Spokane River near Post Falls would provide data for evaluating trends and assessing the efficacy of remediation activities designed to reduce trace-metal loading to streams in the Coeur d'Alene and Spokane River Basins.

\section{Acknowledgments}

The U.S. Geological Survey wishes to thank the U.S. Environmental Protection Agency for providing funding for data collection and publication of this report. Special thanks go to field personnel from the Post Falls Field Office of the U.S. Geological Survey Idaho Water Science Center who were responsible for most of the data collection.

\section{References Cited}

Akaike, Hirotugu, 1981, Likelihood of a model and information criteria: Journal of Econometrics, v. 16, no. 1, p. 3-14.

Barton, G.J., 2002, Dissolved cadmium, zinc, and lead loads from ground-water seepage into the South Fork Coeur d'Alene River system, northern Idaho, 1999: U.S. Geological Survey Water-Resources Investigations Report 2001-4274, 130 p.

Bender, S., 1991, Investigation of the chemical composition and distribution of mining wastes in Killarney Lake, Coeur d'Alene area, northern Idaho: Moscow, University of Idaho, M.S. thesis.

Bolke, E.L., and Vaccaro, J.J., 1981, Digital-model simulation of the hydrologic flow system, with emphasis on ground water, in the Spokane Valley, Washington and Idaho: U.S. Geological Survey Open-File Report 80-1300, 43 p.

Bookstrom, A.A., Box, S.E., Campbell, J.K., Foster, K.I., and Jackson, B.L., 2001, Lead-rich sediments, Coeur d'Alene River Valley, Idaho-Area, volume, tonnage, and lead content: U.S. Geological Survey Open-File Report 2001-140, 44 p. 
Box, S.E., Bookstrom, A.A., and Ikramuddin, M., 2005, Stream-sediment geochemistry in miningimpacted streams - Sediment mobilized by floods in the Coeur d'Alene-Spokane River system, Idaho and Washington: U.S. Geological Survey Scientific Investigations Report 2005-5011, 49 p.

Bradu, Dan, and Mundlak, Yair, 1970, Estimation in lognormal linear models: Journal of the American Statistical Association, v. 65, no. 329, p. 198-211.

Caldwell, R.R., and Bowers, C.L., 2003, Surface-water/ ground-water interaction of the Spokane River and the Spokane Valley/Rathdrum Prairie aquifer, Idaho and Washington; U.S. Geological Survey Water-Resources Investigations Report 2003-4239, 60 p.

Clark, G.M., 2003, Occurrence and transport of cadmium, lead, and zinc in the Spokane River Basin, Idaho and Washington, water years 1999-2001: U.S. Geological Survey Water-Resources Investigations Report 2002-4183, $37 \mathrm{p}$.

Clark, G.M., and Woods, P.F., 2000, Transport of suspended and bedload sediment at eight stations in the Coeur d'Alene River Basin, Idaho: U.S. Geological Survey Open-File Report 2000-472, $26 \mathrm{p}$.

Cohn, T.A., Caulder, D.L., Gilroy, E.J., Zynjuk, L.D., and Summers, R.M., 1992, The validity of a simple statistical model for estimating fluvial constituent loadsAn empirical study involving nutrient loads entering Chesapeake Bay: Water Resources Research, v. 28, no. 9, p. 2,353-2,363.

Cohn, T.A., Delong, L.L, Gilroy, E.J., Hirsch, R.M., and Wells, D.K., 1989, Estimating constituent loads: Water Resources Research, v. 25, no. 5, p. 937-942.

Crawford, C.G., 1991, Estimation of suspended-sediment rating curves and mean suspended-sediment loads: Journal of Hydrology, v. 129, p. 331-348.

Donato, M.M., 2006, Annual trace-metal load estimates and flow-weighted concentrations of cadmium, lead, and zinc in the Spokane River Basin, Idaho and Washington, water years 1999-2004: U.S. Geological Survey Scientific Investigations Report 2006-5188, 38 p.

Fishman, J.J., ed., 1993, Methods of analysis by the U.S. Geological Survey National Water Quality LaboratoryDetermination of inorganic and organic constituents in water and fluvial sediments: U.S. Geological Survey Open-File Report 93-125, 217 p.
Gearhart, C., and Buchanan, J.P, 2000, The hydraulic connection between the Spokane River and the Spokane Aquifer-Gaining and losing reaches of the Spokane River from State Line, Idaho to Spokane, Washington: Spokane County Water Quality Management Program, 106 p.

Gilroy, E.J., Hirsch, R.M., and Cohn, T.A., 1990, Mean square error of regression-based constituent transport estimates: Water Resources Research, v. 26, p. 2,069-2,088.

Goolsby, D.A., Battaglin, W.A., Lawrence, G.B., Artz, R.S., Aulenbach, B.T., Hooper, R.P., Keeney, D.R., and Stensland, G.J., 1999, Flux and sources of nutrients in the Mississippi-Atchafalaya River Basin-Topic 3 report for the integrated assessment on hypoxia in the Gulf of Mexico: Silver Spring, Md., National Oceanic and Atmospheric Administration Coastal Ocean Program Decision Analysis Series No. 17, 130 p.

Grosbois, C.A., Horowitz, A.J., Smith, J.J., and Elrick, K.A., 2001, The effect of mining and related activities on the sediment-trace element geochemistry of Lake Coeur d'Alene, Idaho, USA, Part III, Downstream effectsThe Spokane River Basin: Hydrological Processes, v. 15, p. $855-875$.

Gustavson, K.E., Barnthouse, L.W., Brierley, C.L., Clark, E.H., II, and Ward, C.H., 2007, Superfund and mining megasites: Environmental Science and Technology, v. 41, no. 8 , p. 2,667-2,672. [Also available at http://dx.doi. org/10.1021/es0725091.]

Helsel, D.R., and Hirsch, R.M., 1992, Statistical methods in water resources: New York, Elsevier, 522 p.

Helsel, D.R., Mueller, D.K., and Slack, J.R., 2006, Computer program for the Kendall family of trend tests: U.S. Geological Survey Scientific Investigations Report 2005-5275, 4 p.

Hirsch, R.M., Alexander, R.B., and Smith, R.A., 1991, Selection of methods for the detection and estimation of trends in water quality: Water Resources Research v. 27, p. $803-813$.

Horowitz, A.J., Elrick, K.A., Robbins, J.A., and Cook, R.B., 1995, A summary of the effects of mining and related activities on the sediment-trace element geochemistry of Lake Coeur d'Alene, Idaho, USA: Journal of Geochemical Exploration, v. 52, p. 135-144.

Idaho Department of Environmental Quality and Coeur d'Alene Tribe, 2009, Coeur d'Alene Lake Management Plan: Idaho Department of Environmental Quality and Coeur d'Alene Tribe, $164 \mathrm{p}$. 
Idaho Department of Environmental Quality [various dates], IDAPA 58.01.02-Water Quality Standards, Title 1, Chapter 2: Idaho Department of Environmental Quality, 180 p., accessed May 5, 2014, at http://adminrules.idaho. gov/rules/current/58/index.html.

Judge, C.G., Griffiths, W.E., Hill, R.C., Lutkepohl, H., and Lee, T.C., 1985, The theory and practice of econometrics: New York, Wiley, p. 870-873.

Levesque, V.A., and Oberg, K.A., 2012, Computing discharge using the index velocity method: U.S. Geological Survey Techniques and Methods, book 3, chap. A23, 148 p. [Also available at $\mathrm{http}: / /$ pubs.usgs.gov/tm/3a23/.]

Long, K.R., 1998, Production and disposal of mill tailings in the Coeur d'Alene mining region, Shoshone County, Idaho-Preliminary estimates: U.S. Geological Survey Open-File Report 98-595, 14 p.

Mann, H.B., 1945, Non-parametric tests against trend: Econometrica v. 13, p. 245-259.

Maret, T.R., and Skinner, K.D., 2000, Concentrations of selected trace elements in fish tissue and streambed sediment in the Clark Fork-Pend Oreille and Spokane River Basins, Washington, Idaho, and Montana, 1998: U.S. Geological Survey Water-Resources Investigations Report 2000-4159, 26 p.

Marti, P.B., and Garrigues, R.S., 2001, Spokane River/ Aquifer interaction project results, May-November 1999: Washington State Department of Ecology Report 01-03024, $40 \mathrm{p}$.

Maupin, M.A., and Ivahnenko, T., 2011, Nutrient loading to streams of the continental United States from municipal and industrial effluent: Journal of the American Water Resources Association, v. 47, no. 5, p. 950-964.

Maupin, M.A., and Weakland, R.J., 2009, Water budgets for Coeur d'Alene Lake, Idaho, water years 2000-2005: U.S. Geological Survey Scientific Investigations Report 2009-5184, 16 p.

Mebane, C.A., 2003, Comparisons of cadmium criteria to the results of toxicity testing with species resident to the South Fork Coeur d'Alene River: Boise, Idaho, Idaho Department of Environmental Quality, 44 p., [Also available at http:// www.deq.state.id.us/water-quality/surface-water/waterquality-criteria/site-specific-criteria.aspx.]

Mebane, C.A., 2006, Cadmium risks to freshwater lifeDerivation and validation of low-effect criteria values using laboratory and field studies: U.S. Geological Survey Scientific Investigations Report 2006-5245 (2010 rev.), 130 p. [Also available at http://pubs.usgs.gov/ $\operatorname{sir} / 2006 / 5245 /$.
Mebane, C.A., Dillon, F.S., and Hennessy, D.P., 2012, Acute toxicity of cadmium, lead, zinc, and their mixtures to stream-resident fish and invertebrates: Environmental Toxicology and Chemistry, v. 31, no. 6, p. 1,334-1,348 [Also available at http://dx.doi.org/10.1002/etc.1820,]

Mebane, C.A., Hennessy, D.P., and Dillon, F.S., 2008, Developing acute-to-chronic toxicity ratios for lead, cadmium, and zinc using rainbow trout, a mayfly, and a midge: Water, Air, and Soil Pollution, v. 188, nos. 1-4, p. 41-66. [Also available at http://dx.doi.org/10.1007/ s11270-007-9524-8.]

Mueller, D.K., 1998, Quality of nutrient data from streams and ground water sampled during 1993-95-National WaterQuality Assessment Program: U.S. Geological Survey Open-File Report 98-276, 25 p.

Mueller, D.S., and Wagner, C.R., 2009, Measuring discharge with acoustic Doppler current profilers from a moving boat: U.S. Geological Survey Techniques and Methods, book 3, chap. A22, 72 p. [Also available at http://pubs.water.usgs. gov/tm3a22.]

National Academy of Sciences, 2005, Superfund and mining megasites-Lessons from the Coeur d'Alene River Basin: Washington D.C., The National Academies Press, 484 p.

Patton, C.J., and Kryskalla, J.R., 2003, Methods of analysis by the U.S. Geological Survey National Water Quality Laboratory-Evaluation of alkaline persulfate digestion as an alternative to Kjeldahl digestion for determination of total and dissolved nitrogen and phosphorus in water: U.S. Geological Survey Water-Resources Investigations Report 2003-4174, 33 p. [Also available at http://nwql.usgs. gov/Public/pubs/WRIR03-4174/WRIR03-4174.pdf.]

Pritt, J.W., and Raese, J.W., eds., 1995, Quality assurance/ quality control manual: National Water Quality Laboratory, U.S. Geological Survey Open-File Report 95-443, 35 p.

Rantz, S.E., and others, 1982, Measurement and computation of streamflow: U.S. Geological Survey Water-Supply Paper 2175, v. 2, 631 p. [Also available at http://pubs.usgs. gov/wsp/wsp2175/html/wsp2175_vol2.html.]

Runkel, R.L., Crawford, C.G., and Cohn, T.A., 2004, Load Estimator (LOADEST) - A FORTRAN program for estimating constituent loads in streams and rivers: U.S. Geological Survey Techniques and Methods, book 4, chap. A5, 69 p. [Also available at http://pubs.usgs.gov/ $\mathrm{tm} / 2005 / \mathrm{tm} 4 \mathrm{~A} 5 /$.

Smith, R.A., Alexander, R.B., and Wolman, M.G., 1987, Water-quality trends in the Nation's rivers: Science, v. 235, p. $1,607-1,615$. 
Turnipseed, D.P., and Sauer, V.B., 2010, Discharge measurements at gaging stations: U.S. Geological Survey Techniques and Methods, book 3, chap. A8, 87 p. [Also available at http://pubs.usgs.gov/tm/tm3-a8/.]

U.S. Environmental Protection Agency, 2001, Coeur d'Alene Basin remedial investigation/feasibility study, Remedial investigation, Final (Revision 2): Prepared by URS-Greiner Inc. and CH2M Hill, October, 2001.

U.S. Environmental Protection Agency, 2002a, Bunker Hill Mining and Metallurgical Complex-Operable Unit 3, Record of decision: Seattle, Wash., U.S. Environmental Protection Agency, Region 10, 507 p.

U.S. Environmental Protection Agency, 2002b, National recommended water quality criteria-2002: U.S. Environmental Protection Agency, EPA-822-R-02-047, $36 \mathrm{p}$.

U.S. Environmental Protection Agency, 2004, Basin environmental monitoring plan, Bunker Hill Mining and Metallurgical Complex-Operable Unit 3, March 2004: Prepared by URS Group, Inc. and CH2M Hill for U.S. Environmental Protection Agency, Response Action Contract No. 68-W-98-228, variously paged.

U.S. Environmental Protection Agency, 2010, 2010 Five year review for the Bunker Hill Mining and Metallurgical Complex Superfund Site Operable Units 1, 2, and 3, Idaho and Washington: Prepared by U.S. Environmental Protection Agency, Region 10, Seattle, Wash., variously paged.

U.S. Environmental Protection Agency, 2012, Focused feasibility study report, Upper basin of the Coeur d'Alene River, Bunker Hill Mining and Metallurgical Complex Superfund Site, Volume 1 addendum to the draft final report: Prepared by CH2MHill for the U.S. Environmental Protection Agency, AES10 Task Order 49 Architect and Engineering Services Contract No. 68-S7-04-01, variously paged.
U.S. Environmental Protection Agency, 2014, STORET database: U.S. Environmental Protection agency database, accessed March 2014, at http://www.epa.gov/storet/dbtop. html.

U.S. Geological Survey [various dates], National field manual for the collection of water-quality data: U.S. Geological Survey Techniques of Water-Resources Investigations, book 9, chaps. A1-A9. [Also available online at http://pubs. water.usgs.gov/twri9A.]

Weiner, E.R, 2012, Applications of environmental aquatic chemistry-A practical guide (3d ed.): Boca Raton, Fla., CRC Press, $618 \mathrm{p}$.

Windward Environmental, 2002, Development of site-specific water quality criteria for the South Fork Coeur d'Alene River, Idaho - Derivation of acute and chronic criteria for lead and zinc: Seattle, Wash., prepared by Windward Environmental for the Idaho Department of Environmental Quality, 32 p. [Also available at https://www.deq.idaho.gov/ media/445309-sfcda_criteria_lead_zinc.pdf.]

Wood, M.S., and Beckwith, M.A., 2008, Coeur d'Alene Lake, Idaho-Insights gained from limnological studies of 1991-92 and 2004-06: U.S. Geological Survey Scientific Investigations Report 2008-5168, 39 p.

Woods, P.F., 2001, Concentrations and loads of cadmium, lead, and zinc measured on the ascending and descending limbs of the 1999 snowmelt-runoff hydrographs for nine water-quality stations, Coeur d'Alene River Basin, Idaho: U.S. Geological Survey Open-File Report 2000-310, 42 p.

Woods, P.F., and Beckwith, M.A., 1997, Nutrient and traceelement enrichment of Coeur d'Alene Lake, Idaho: U.S. Geological Survey Water-Supply Paper 2485, 93 p. 


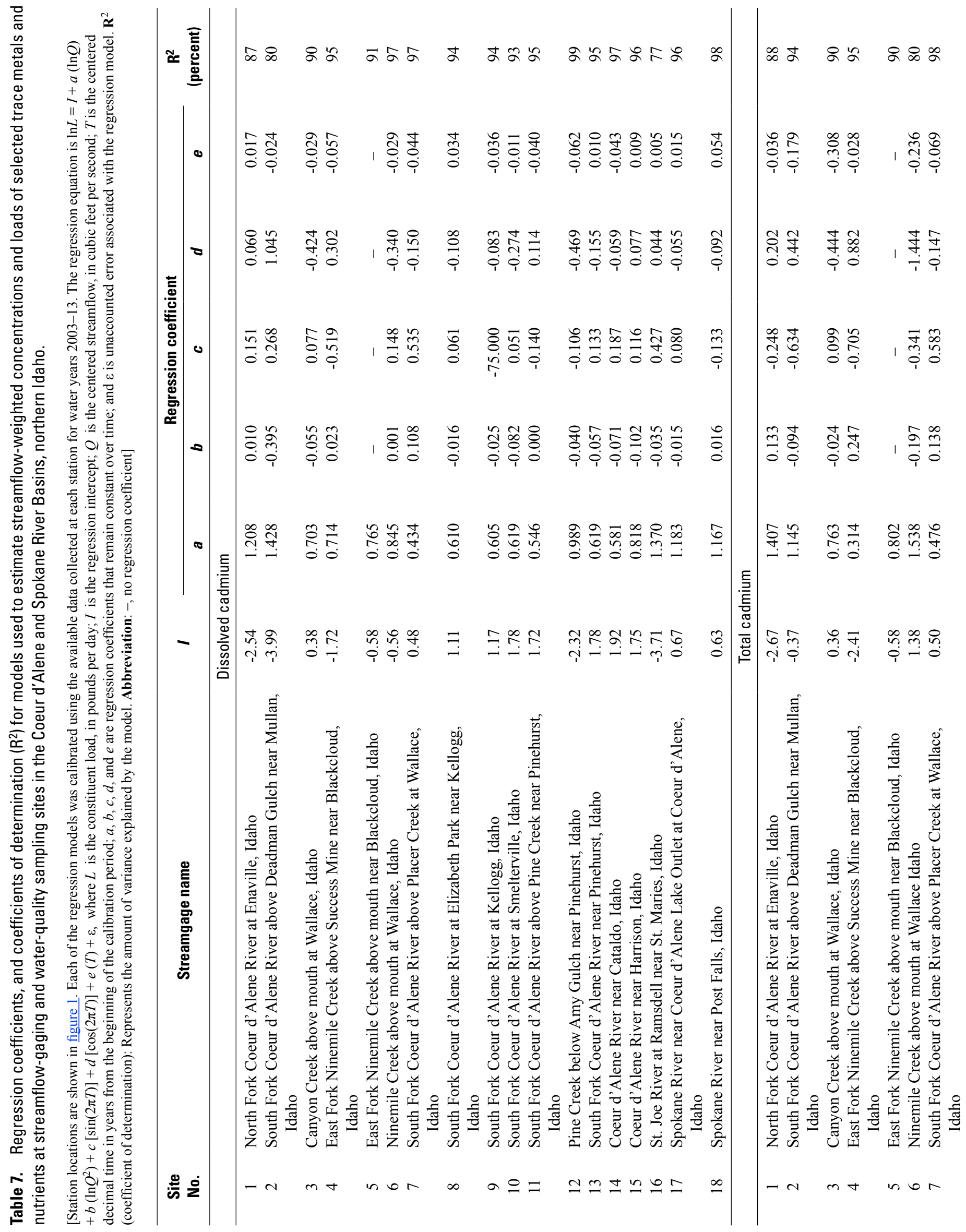


Table 7

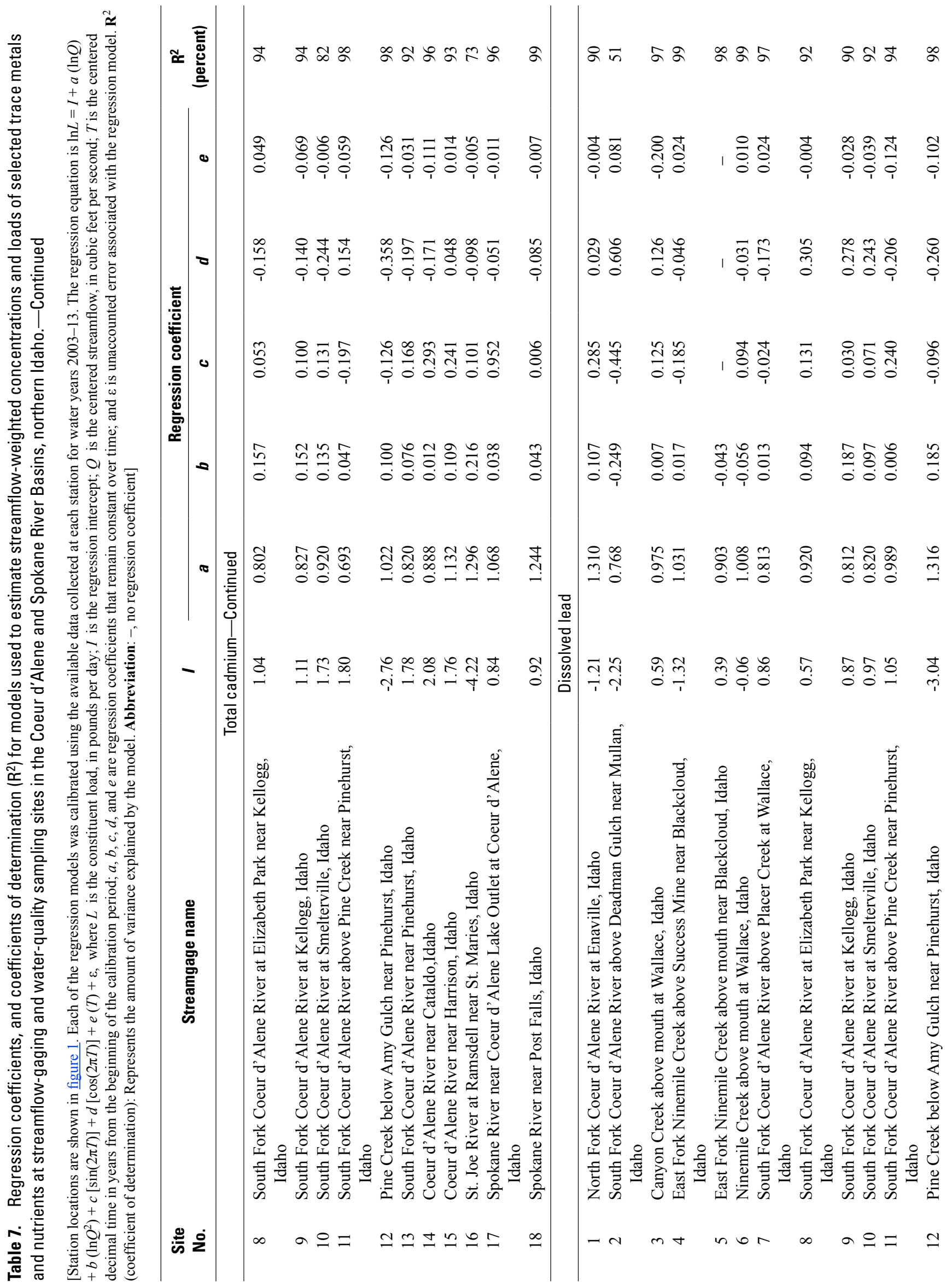




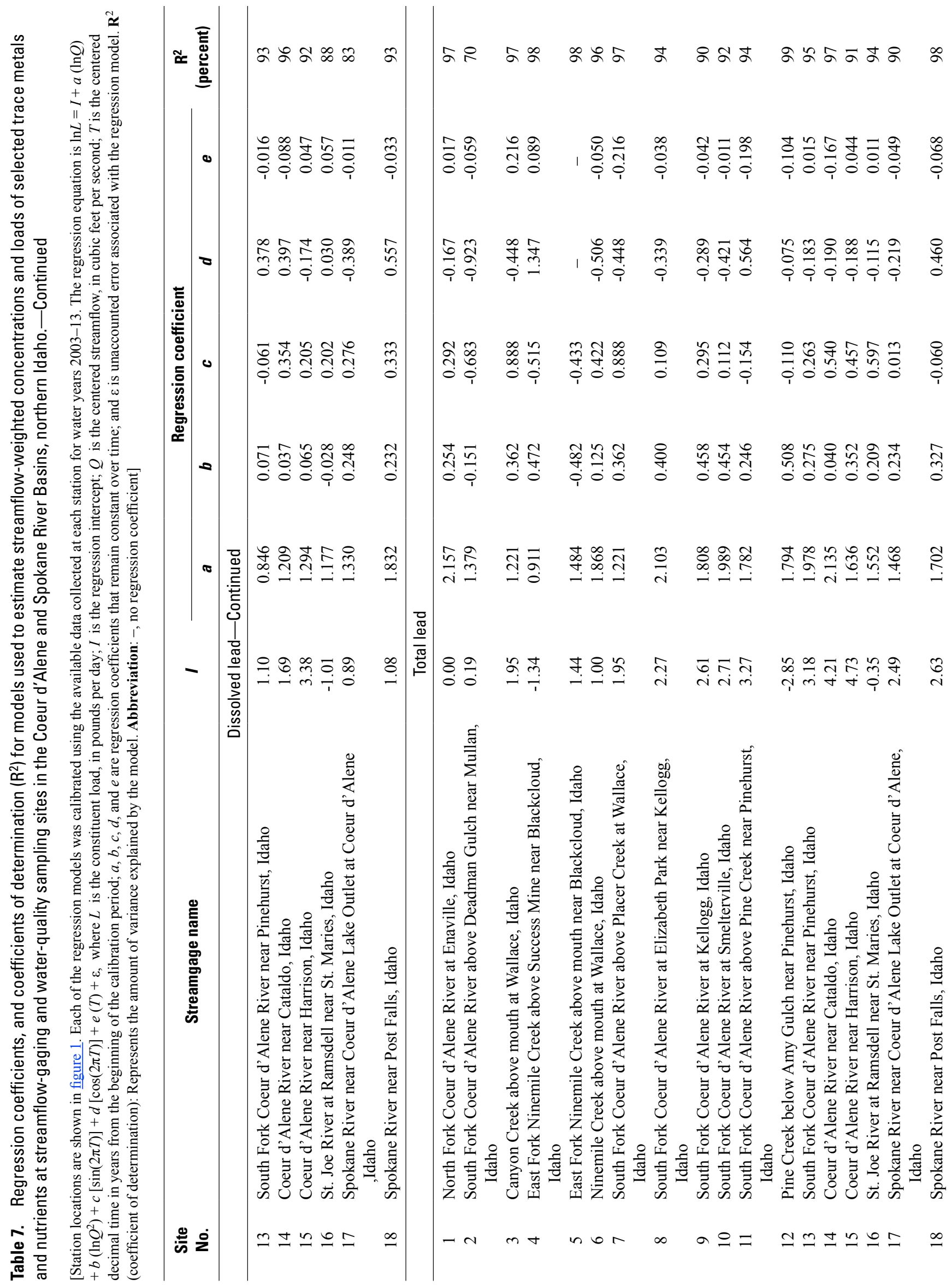


Table 7

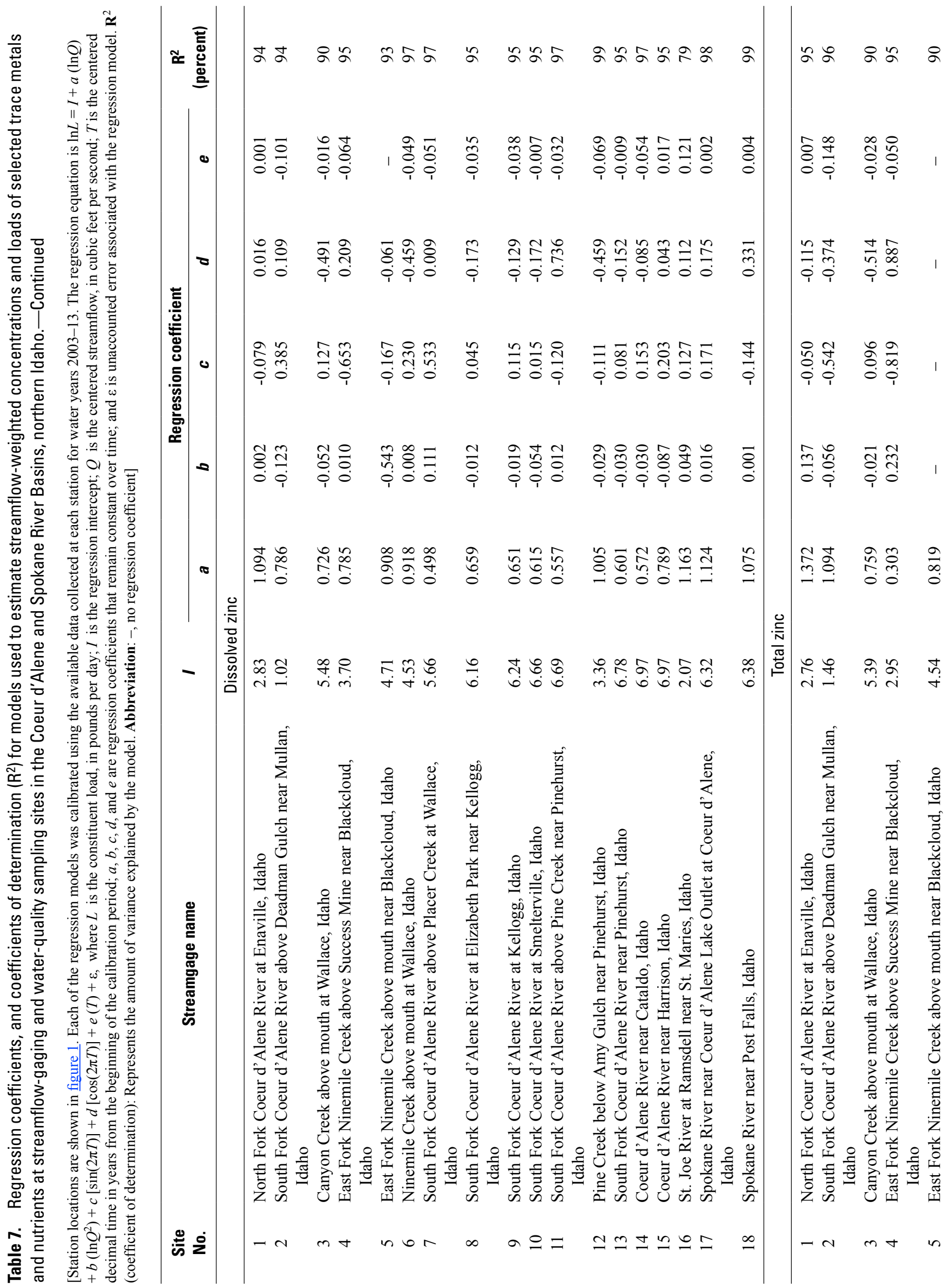




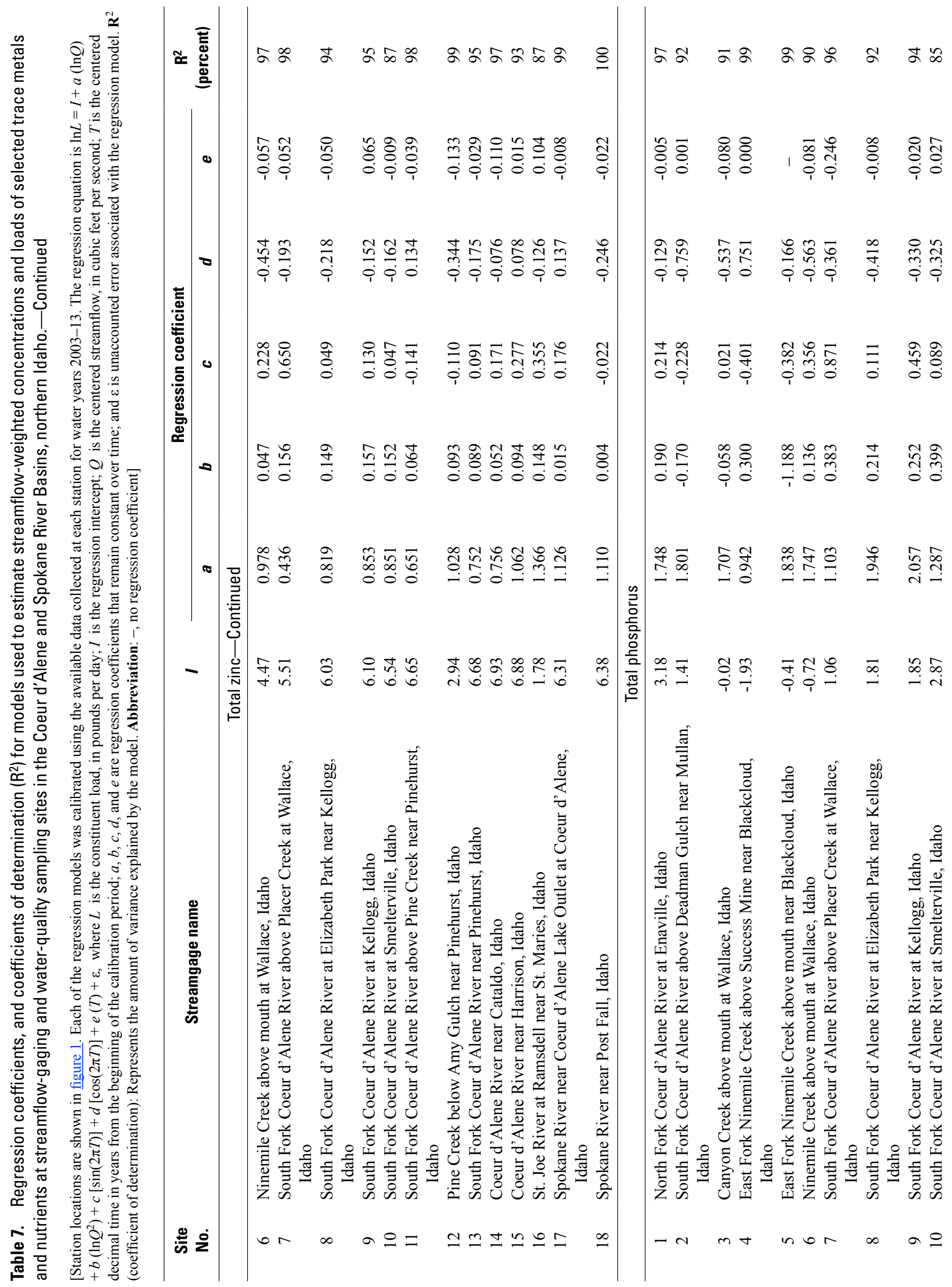




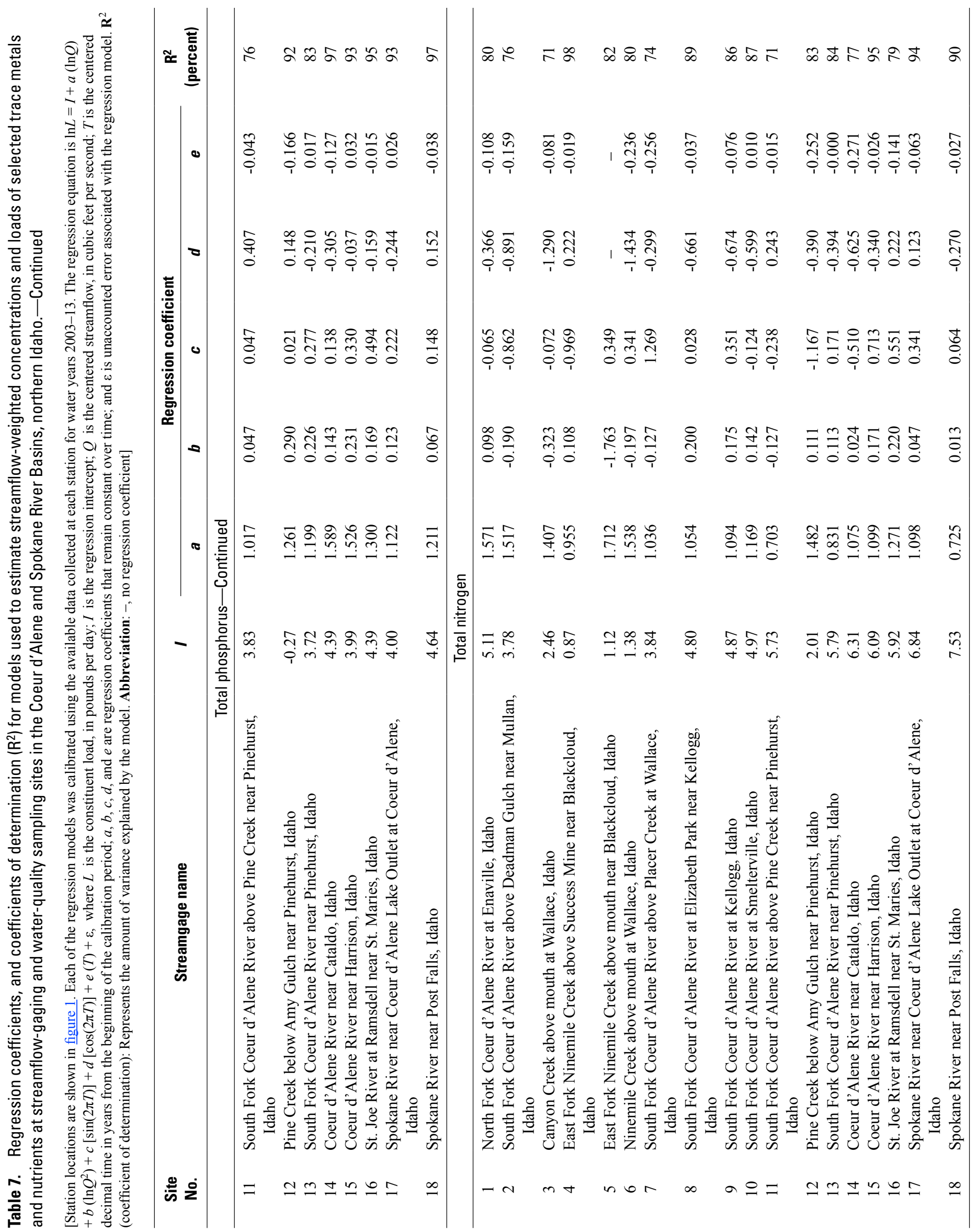


Table 8. Annual loads of dissolved and total cadmium, lead, and zinc and 95-percent confidence intervals for streamflow-gaging and water-quality sampling sites in the Coeur d'Alene and Spokane River Basins, northern Idaho, water years 2009-13.

[Locations sites are shown in figure 1. Abbreviations: ton/yr, ton per year; C.I., confidence interval; NFCDR, North Fork Coeur d'Alene River; SFCDR, South Fork Coeur d'Alene River; CDR, Coeur d'Alene River; EF, East Fork; ID, Idaho]

\begin{tabular}{|c|c|c|c|c|c|c|c|c|c|c|}
\hline \multirow{3}{*}{$\begin{array}{l}\text { Site } \\
\text { No. }\end{array}$} & \multirow{3}{*}{ Streamgage name } & \multicolumn{9}{|c|}{ Water year 2009} \\
\hline & & \multicolumn{3}{|c|}{ Dissolved cadmium (ton/yr) } & \multicolumn{3}{|c|}{ Total cadmium (ton/yr) } & \multicolumn{3}{|c|}{ Dissolved lead (ton/yr) } \\
\hline & & $\begin{array}{l}\text { Estimated } \\
\text { load }\end{array}$ & $\begin{array}{l}\text { Lower } \\
\text { 95-percent } \\
\text { C.I. }\end{array}$ & $\begin{array}{c}\text { Upper } \\
\text { 95-percent } \\
\text { C.I. }\end{array}$ & $\begin{array}{l}\text { Estimated } \\
\text { load }\end{array}$ & $\begin{array}{l}\text { Lower } \\
\text { 95-percent } \\
\text { C.I. }\end{array}$ & $\begin{array}{c}\text { Upper } \\
\text { 95-percent } \\
\text { C.I. }\end{array}$ & $\begin{array}{l}\text { Estimated } \\
\text { load }\end{array}$ & $\begin{array}{c}\text { Lower } \\
\text { 95-percent } \\
\text { C.I. }\end{array}$ & $\begin{array}{c}\text { Upper } \\
\text { 95-percent } \\
\text { C.I. }\end{array}$ \\
\hline 1 & NFCDR at Enaville ID & 0.042 & 0.026 & 0.064 & 0.079 & 0.041 & 0.139 & 0.177 & 0.114 & 0.265 \\
\hline 3 & $\begin{array}{l}\text { Canyon Creek above mouth } \\
\text { at Wallace ID }\end{array}$ & 0.385 & 0.322 & 0.457 & 0.386 & 0.319 & 0.463 & 0.507 & 0.446 & 0.574 \\
\hline 4 & $\begin{array}{l}\text { EF Ninemile Creek above } \\
\text { Success Mine near } \\
\text { Blackcloud ID }\end{array}$ & 0.056 & 0.037 & 0.082 & 0.064 & 0.036 & 0.111 & 0.078 & 0.063 & 0.095 \\
\hline 6 & $\begin{array}{l}\text { Ninemile Creek above } \\
\text { mouth at Wallace ID }\end{array}$ & 0.184 & 0.159 & 0.211 & 0.189 & 0.160 & 0.222 & 0.286 & 0.257 & 0.317 \\
\hline 7 & $\begin{array}{l}\text { SFCDR above Placer Creek } \\
\text { at Wallace ID }\end{array}$ & 0.716 & 0.556 & 0.908 & 0.806 & 0.654 & 0.984 & 0.665 & 0.465 & 0.924 \\
\hline 8 & $\begin{array}{l}\text { SFCDR at Elizabeth Park } \\
\text { near Kellogg ID }\end{array}$ & 0.938 & 0.846 & 1.04 & 1.06 & 0.921 & 1.22 & 0.714 & 0.588 & 0.858 \\
\hline 9 & SFCDR at Kellogg ID & 1.00 & 0.896 & 1.12 & 1.15 & 0.977 & 1.35 & 0.977 & 0.792 & 1.19 \\
\hline 10 & SFCDR at Smelterville ID & 1.72 & 1.52 & 1.91 & 2.22 & 1.64 & 2.93 & 1.07 & 0.890 & 1.27 \\
\hline 11 & $\begin{array}{l}\text { SFCDR above Pine Creek } \\
\text { near Pinehurst ID }\end{array}$ & 1.87 & 1.63 & 2.15 & 2.11 & 1.90 & 2.34 & 1.32 & 0.984 & 1.74 \\
\hline 16 & $\begin{array}{l}\text { St. Joe River at Ramsdell } \\
\text { near St. Maries ID }\end{array}$ & 0.025 & 0.012 & 0.047 & 0.030 & 0.012 & 0.065 & 0.269 & 0.184 & 0.379 \\
\hline 17 & $\begin{array}{l}\text { Spokane River near Coeur } \\
\text { d'Alene Lake Outlet at } \\
\text { Coeur d'Alene ID }\end{array}$ & 1.17 & 0.983 & 1.39 & 1.38 & 1.18 & 1.60 & 3.98 & 2.24 & 6.58 \\
\hline 18 & $\begin{array}{l}\text { Spokane River near } \\
\text { Post Falls ID }\end{array}$ & 1.01 & 0.802 & 1.26 & 1.39 & 1.19 & 1.61 & 3.00 & 1.79 & 4.72 \\
\hline
\end{tabular}


Table 8. Annual loads of dissolved and total cadmium, lead, and zinc and 95-percent confidence intervals for streamflow-gaging and water-quality sampling sites in the Coeur d'Alene and Spokane River Basins, northern Idaho, water years 2009-13.—Continued

[Locations of sites are shown in figure 1. Abbreviations: ton/yr, ton per year; C.I., confidence interval; NFCDR, North Fork Coeur d'Alene River; SFCDR, South Fork Coeur d'Alene River; CDR, Coeur d'Alene River; EF, East Fork; ID, Idaho]

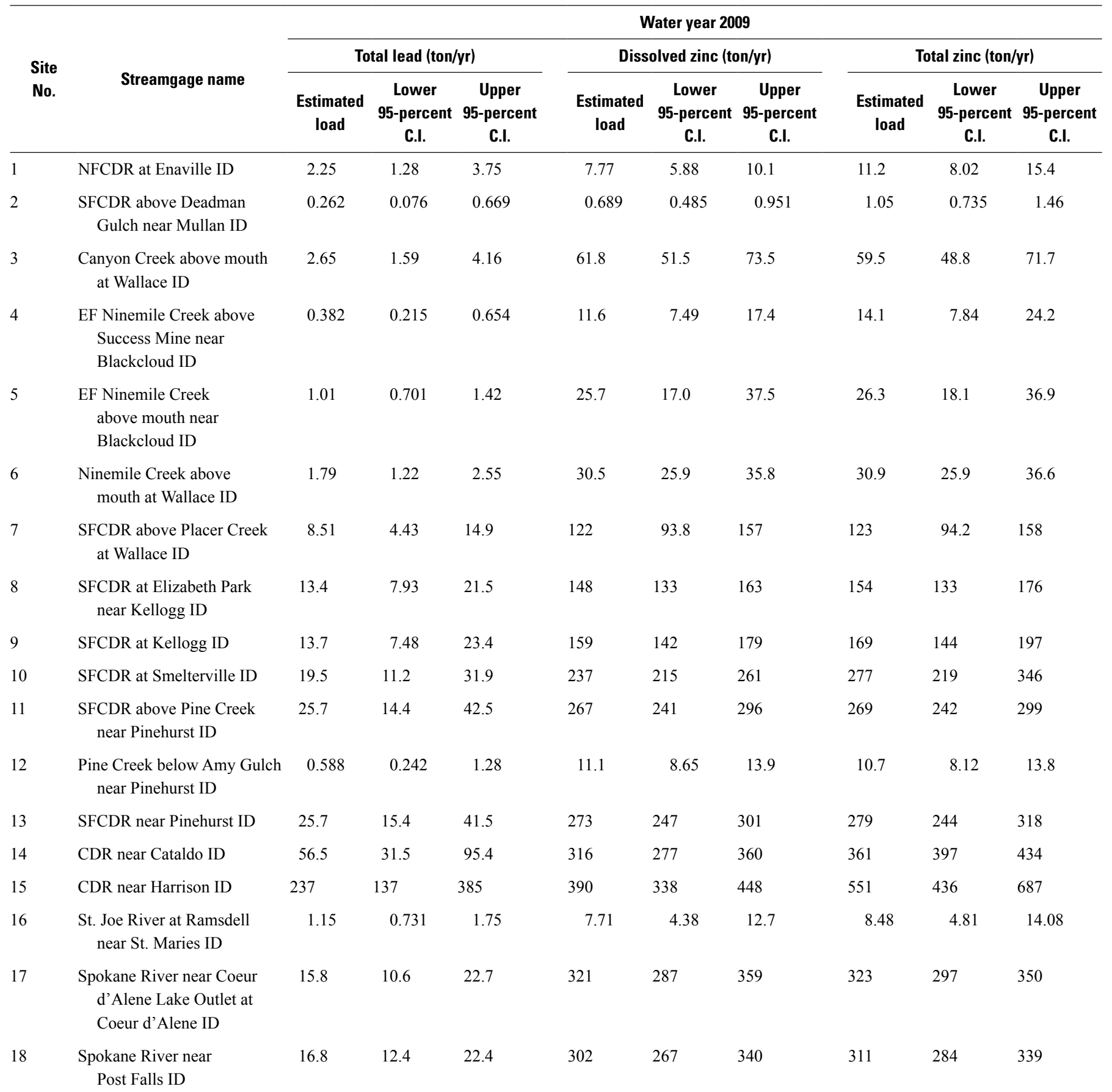


Table 8. Annual loads of dissolved and total cadmium, lead, and zinc and 95-percent confidence intervals for streamflow-gaging and water-quality sampling sites in the Coeur d'Alene and Spokane River Basins, northern Idaho, water years 2009-13.—Continued

[Locations of sites are shown in figure 1. Abbreviations: ton/yr, ton per year; C.I., confidence interval; NFCDR, North Fork Coeur d'Alene River; SFCDR, South Fork Coeur d'Alene River; CDR, Coeur d'Alene River; EF, East Fork; ID, Idaho]

\begin{tabular}{|c|c|c|c|c|c|c|c|c|c|c|}
\hline \multirow{3}{*}{$\begin{array}{l}\text { Site } \\
\text { No. }\end{array}$} & \multirow{3}{*}{ Streamgage name } & \multicolumn{9}{|c|}{ Water year 2010} \\
\hline & & \multicolumn{3}{|c|}{ Dissolved cadmium (ton/yr) } & \multicolumn{3}{|c|}{ Total cadmium (ton/yr) } & \multicolumn{3}{|c|}{ Dissolved lead (ton/yr) } \\
\hline & & $\begin{array}{l}\text { Estimated } \\
\text { load }\end{array}$ & $\begin{array}{l}\text { Lower } \\
\text { 95-percent } \\
\text { C.I. }\end{array}$ & $\begin{array}{c}\text { Upper } \\
\text { 95-percent } \\
\text { C.I. }\end{array}$ & $\begin{array}{l}\text { Estimated } \\
\text { load }\end{array}$ & $\begin{array}{l}\text { Lower } \\
\text { 95-percent } \\
\text { C.I. }\end{array}$ & $\begin{array}{c}\text { Upper } \\
\text { 95-percent } \\
\text { C.I. }\end{array}$ & $\begin{array}{l}\text { Estimated } \\
\text { load }\end{array}$ & $\begin{array}{l}\text { Lower } \\
\text { 95-percent } \\
\text { C.I. }\end{array}$ & $\begin{array}{c}\text { Upper } \\
\text { 95-percent } \\
\text { C.I. }\end{array}$ \\
\hline 1 & NFCDR at Enaville ID & 0.033 & 0.021 & 0.064 & 0.045 & 0.024 & 0.078 & 0.123 & 0.079 & 0.182 \\
\hline 3 & $\begin{array}{l}\text { Canyon Creek above mouth } \\
\text { at Wallace ID }\end{array}$ & 0.304 & 0.249 & 0.369 & 0.300 & 0.242 & 0.368 & 0.416 & 0.363 & 0.475 \\
\hline 4 & $\begin{array}{l}\text { EF Ninemile Creek above } \\
\text { Success Mine near } \\
\text { Blackcloud ID }\end{array}$ & 0.380 & 0.023 & 0.060 & 0.049 & 0.023 & 0.099 & 0.059 & 0.048 & 0.073 \\
\hline 6 & $\begin{array}{l}\text { Ninemile Creek above } \\
\text { mouth at Wallace ID }\end{array}$ & 0.112 & 0.096 & 0.130 & 0.107 & 0.089 & 0.126 & 0.177 & 0.159 & 0.197 \\
\hline 7 & $\begin{array}{l}\text { SFCDR above Placer Creek } \\
\text { at Wallace ID }\end{array}$ & 0.595 & 0.454 & 0.771 & 0.650 & 0.517 & 0.809 & 0.536 & 0.392 & 0.720 \\
\hline 8 & $\begin{array}{l}\text { SFCDR at Elizabeth Park } \\
\text { near Kellogg ID }\end{array}$ & 0.735 & 0.655 & 0.823 & 0.747 & 0.635 & 0.873 & 0.524 & 0.425 & 0.639 \\
\hline 9 & SFCDR at Kellogg ID & 0.784 & 0.690 & 0.888 & 0.787 & 0.653 & 0.940 & 0.729 & 0.579 & 0.905 \\
\hline 10 & SFCDR at Smelterville ID & 1.36 & 1.19 & 1.54 & 1.56 & 1.13 & 2.11 & 0.774 & 0.636 & 0.933 \\
\hline 11 & $\begin{array}{l}\text { SFCDR above Pine Creek } \\
\text { near Pinehurst ID }\end{array}$ & 1.49 & 1.29 & 1.71 & 1.55 & 1.39 & 1.79 & 0.835 & 0.630 & 1.09 \\
\hline 16 & $\begin{array}{l}\text { St. Joe River at Ramsdell } \\
\text { near St. Maries ID }\end{array}$ & 0.013 & 0.006 & 0.024 & 0.013 & 0.005 & 0.026 & 0.169 & 0.114 & 0.240 \\
\hline 17 & $\begin{array}{l}\text { Spokane River near Coeur } \\
\text { d'Alene Lake Outlet at } \\
\text { Coeur d'Alene ID }\end{array}$ & 0.742 & 0.621 & 0.881 & 0.874 & 0.748 & 1.02 & 1.86 & 1.05 & 3.07 \\
\hline 18 & $\begin{array}{l}\text { Spokane River near } \\
\text { Post Falls ID }\end{array}$ & 0.649 & 0.520 & 0.800 & 0.809 & 0.702 & 0.929 & 1.50 & 0.940 & 2.26 \\
\hline
\end{tabular}


Table 8. Annual loads of dissolved and total cadmium, lead, and zinc and 95-percent confidence intervals for streamflow-gaging and water-quality sampling sites in the Coeur d'Alene and Spokane River Basins, northern Idaho, water years 2009-13.—Continued

[Locations of sites are shown in figure 1. Abbreviations: ton/yr, ton per year; C.I., confidence interval; NFCDR, North Fork Coeur d'Alene River; SFCDR, South Fork Coeur d'Alene River; CDR, Coeur d'Alene River; EF, East Fork; ID, Idaho]

\begin{tabular}{|c|c|c|c|c|c|c|c|c|c|c|}
\hline \multirow{3}{*}{$\begin{array}{l}\text { Site } \\
\text { No. }\end{array}$} & \multirow{3}{*}{ Streamgage name } & \multicolumn{9}{|c|}{ Water year 2010} \\
\hline & & \multicolumn{3}{|c|}{ Total lead (ton/yr) } & \multicolumn{3}{|c|}{ Dissolved zinc (ton/yr) } & \multicolumn{3}{|c|}{ Total zinc (ton/yr) } \\
\hline & & $\begin{array}{l}\text { Estimated } \\
\text { load }\end{array}$ & $\begin{array}{l}\text { Lower } \\
\text { 95-percent } \\
\text { C.I. }\end{array}$ & $\begin{array}{l}\text { Upper } \\
\text { 95-percent } \\
\text { C.I. }\end{array}$ & $\begin{array}{l}\text { Estimated } \\
\text { load }\end{array}$ & $\begin{array}{c}\text { Lower } \\
\text { 95-percent } \\
\text { C.I. }\end{array}$ & $\begin{array}{c}\text { Upper } \\
\text { 95-percent } \\
\text { C.I. }\end{array}$ & $\begin{array}{c}\text { Estimated } \\
\text { load }\end{array}$ & $\begin{array}{c}\text { Lower } \\
\text { 95-percent } \\
\text { C.I. }\end{array}$ & $\begin{array}{l}\text { Upper } \\
\text { 95-percent } \\
\text { C.I. }\end{array}$ \\
\hline 1 & NFCDR at Enaville ID & 0.706 & 0.443 & 1.07 & 6.20 & 4.65 & 8.10 & 6.77 & 4.91 & 9.10 \\
\hline 3 & $\begin{array}{l}\text { Canyon Creek above mouth } \\
\text { at Wallace ID }\end{array}$ & 1.64 & 0.980 & 2.59 & 48.8 & 39.8 & 59.4 & 46.4 & 37.1 & 57.3 \\
\hline 4 & $\begin{array}{l}\text { EF Ninemile Creek above } \\
\text { Success Mine near } \\
\text { Blackcloud ID }\end{array}$ & 0.248 & 0.132 & 0.462 & 7.48 & 4.61 & 11.790 & 10.3 & 4.84 & 21.2 \\
\hline 6 & $\begin{array}{l}\text { Ninemile Creek above } \\
\text { mouth at Wallace ID }\end{array}$ & 0.454 & 0.309 & 0.644 & 17.1 & 14.3 & 20.3 & 16.5 & 13.6 & 19.8 \\
\hline 7 & $\begin{array}{l}\text { SFCDR above Placer Creek } \\
\text { at Wallace ID }\end{array}$ & 3.78 & 2.05 & 6.59 & 98.5 & 74.2 & 129 & 103 & 76.9 & 137 \\
\hline 8 & $\begin{array}{l}\text { SFCDR at Elizabeth Park } \\
\text { near Kellogg ID }\end{array}$ & 3.62 & 2.24 & 5.55 & 112 & 99.9 & 126 & 106 & 90.8 & 124 \\
\hline 9 & SFCDR at Kellogg ID & 4.52 & 2.54 & 7.47 & 121 & 106 & 138 & 114 & 95.3 & 136 \\
\hline 10 & SFCDR at Smelterville ID & 5.74 & 3.49 & 8.90 & 190 & 171 & 212 & 199 & 154 & 253 \\
\hline 11 & $\begin{array}{l}\text { SFCDR above Pine Creek } \\
\text { near Pinehurst ID }\end{array}$ & 7.81 & 4.64 & 12.4 & 214 & 193 & 238 & 206 & 185 & 230 \\
\hline 16 & $\begin{array}{l}\text { St. Joe River at Ramsdell } \\
\text { near St. Maries ID }\end{array}$ & 0.367 & 0.253 & 0.517 & 5.09 & 2.89 & 8.33 & 4.00 & 2.36 & 6.35 \\
\hline 17 & $\begin{array}{l}\text { Spokane River near Coeur } \\
\text { d'Alene Lake Outlet at } \\
\text { Coeur d'Alene ID }\end{array}$ & 7.09 & 4.78 & 10.1 & 197 & 176 & 220 & 196 & 180 & 213 \\
\hline 18 & $\begin{array}{l}\text { Spokane River near } \\
\text { Post Falls ID }\end{array}$ & 7.56 & 5.77 & 9.72 & 185 & 164 & 208 & 186 & 172 & 202 \\
\hline
\end{tabular}


Table 8. Annual loads of dissolved and total cadmium, lead, and zinc and 95-percent confidence intervals for streamflow-gaging and water-quality sampling sites in the Coeur d'Alene and Spokane River Basins, northern Idaho, water years 2009-13.-Continued

[Locations of sites are shown in figure 1. Abbreviations: ton/yr, ton per year; C.I., confidence interval; NFCDR, North Fork Coeur d'Alene River; SFCDR, South Fork Coeur d'Alene River; CDR, Coeur d'Alene River; EF, East Fork; ID, Idaho]

\begin{tabular}{|c|c|c|c|c|c|c|c|c|c|c|}
\hline \multirow{3}{*}{$\begin{array}{l}\text { Site } \\
\text { No. }\end{array}$} & \multirow{3}{*}{ Streamgage name } & \multicolumn{9}{|c|}{ Water year 2011} \\
\hline & & \multicolumn{3}{|c|}{ Dissolved cadmium (ton/yr) } & \multicolumn{3}{|c|}{ Total cadmium (ton/yr) } & \multicolumn{3}{|c|}{ Dissolved lead (ton/yr) } \\
\hline & & $\begin{array}{l}\text { Estimated } \\
\text { load }\end{array}$ & $\begin{array}{l}\text { Lower } \\
\text { 95-percent } \\
\text { C.I. }\end{array}$ & $\begin{array}{c}\text { Upper } \\
\text { 95-percent } \\
\text { C.I. }\end{array}$ & $\begin{array}{l}\text { Estimated } \\
\text { load }\end{array}$ & $\begin{array}{l}\text { Lower } \\
\text { 95-percent } \\
\text { C.I. }\end{array}$ & $\begin{array}{c}\text { Upper } \\
\text { 95-percent } \\
\text { C.I. }\end{array}$ & $\begin{array}{l}\text { Estimated } \\
\text { load }\end{array}$ & $\begin{array}{c}\text { Lower } \\
\text { 95-percent } \\
\text { C.I. }\end{array}$ & $\begin{array}{c}\text { Upper } \\
\text { 95-percent } \\
\text { C.I. }\end{array}$ \\
\hline 1 & NFCDR at Enaville ID & 0.086 & 0.500 & 0.138 & 0.166 & 0.078 & 0.315 & 0.406 & 0.241 & 0.648 \\
\hline 3 & $\begin{array}{l}\text { Canyon Creek above mouth } \\
\text { at Wallace ID }\end{array}$ & 0.476 & 0.391 & 0.575 & 0.481 & 0.389 & 0.587 & 0.773 & 0.669 & 0.890 \\
\hline 4 & $\begin{array}{l}\text { EF Ninemile Creek above } \\
\text { Success Mine near } \\
\text { Blackcloud ID }\end{array}$ & 0.070 & 0.045 & 0.104 & 0.068 & 0.041 & 0.110 & 0.414 & 0.114 & 0.173 \\
\hline 6 & $\begin{array}{l}\text { Ninemile Creek above } \\
\text { mouth at Wallace ID }\end{array}$ & 0.248 & 0.215 & 0.286 & 0.258 & 0.217 & 0.305 & 0.445 & 0.399 & 0.495 \\
\hline 7 & $\begin{array}{l}\text { SFCDR above Placer Creek } \\
\text { at Wallace ID }\end{array}$ & 0.766 & 0.652 & 0.894 & 0.830 & 0.726 & 0.946 & 1.04 & 0.829 & 1.30 \\
\hline 8 & $\begin{array}{l}\text { SFCDR at Elizabeth Park } \\
\text { near Kellogg ID }\end{array}$ & 1.15 & 1.03 & 1.29 & 1.45 & 1.23 & 1.69 & 1.14 & 0.913 & 1.40 \\
\hline 9 & SFCDR at Kellogg ID & 1.23 & 1.08 & 1.38 & 1.51 & 1.25 & 1.80 & 1.42 & 1.13 & 1.78 \\
\hline 10 & SFCDR at Smelterville ID & 2.20 & 1.93 & 2.49 & 3.49 & 2.48 & 4.79 & 1.51 & 1.23 & 1.83 \\
\hline 11 & $\begin{array}{l}\text { SFCDR above Pine Creek } \\
\text { near Pinehurst ID }\end{array}$ & 2.21 & 1.95 & 2.49 & 2.59 & 2.36 & 2.84 & 1.68 & 1.29 & 2.16 \\
\hline 16 & $\begin{array}{l}\text { St. Joe River at Ramsdell } \\
\text { near St. Maries ID }\end{array}$ & 0.044 & 0.019 & 0.085 & 0.068 & 0.023 & 0.158 & 0.491 & 0.319 & 0.722 \\
\hline 17 & $\begin{array}{l}\text { Spokane River near Coeur } \\
\text { d'Alene Lake Outlet at } \\
\text { Coeur d'Alene ID }\end{array}$ & 2.01 & 1.65 & 2.43 & 2.21 & 1.86 & 2.61 & 8.00 & 4.15 & 14.0 \\
\hline 18 & $\begin{array}{l}\text { Spokane River near } \\
\text { Post Falls ID }\end{array}$ & 1.95 & 1.53 & 2.43 & 5.20 & 2.15 & 2.90 & 8.19 & 4.72 & 13.3 \\
\hline
\end{tabular}


Table 8. Annual loads of dissolved and total cadmium, lead, and zinc and 95-percent confidence intervals for streamflow-gaging and water-quality sampling sites in the Coeur d'Alene and Spokane River Basins, northern Idaho, water years 2009-13. - Continued

[Locations of sites are shown in figure 1. Abbreviations: ton/yr, ton per year; C.I., confidence interval; NFCDR, North Fork Coeur d'Alene River; SFCDR, South Fork Coeur d'Alene River; CDR, Coeur d'Alene River; EF, East Fork; ID, Idaho]

\begin{tabular}{|c|c|c|c|c|c|c|c|c|c|c|}
\hline \multirow{3}{*}{$\begin{array}{l}\text { Site } \\
\text { No. }\end{array}$} & \multirow{3}{*}{ Streamgage name } & \multicolumn{9}{|c|}{ Water year 2011} \\
\hline & & \multicolumn{3}{|c|}{ Total lead (ton/yr) } & \multicolumn{3}{|c|}{ Dissolved zinc (ton/yr) } & \multicolumn{3}{|c|}{ Total zinc (ton/yr) } \\
\hline & & $\begin{array}{l}\text { Estimated } \\
\text { load }\end{array}$ & $\begin{array}{l}\text { Lower } \\
\text { 95-percent } \\
\text { C.I. }\end{array}$ & $\begin{array}{l}\text { Upper } \\
\text { 95-percent } \\
\text { C.I. }\end{array}$ & $\begin{array}{l}\text { Estimated } \\
\text { load }\end{array}$ & $\begin{array}{c}\text { Lower } \\
\text { 95-percent } \\
\text { C.I. }\end{array}$ & $\begin{array}{c}\text { Upper } \\
\text { 95-percent } \\
\text { C.I. }\end{array}$ & $\begin{array}{l}\text { Estimated } \\
\text { load }\end{array}$ & $\begin{array}{l}\text { Lower } \\
\text { 95-percent } \\
\text { C.I. }\end{array}$ & $\begin{array}{l}\text { Upper } \\
\text { 95-percent } \\
\text { C.I. }\end{array}$ \\
\hline 1 & NFCDR at Enaville ID & 10.7 & 5.19 & 20.2 & 14.6 & 10.6 & 19.5 & 27.7 & 18.5 & 40.2 \\
\hline 3 & $\begin{array}{l}\text { Canyon Creek above mouth } \\
\text { at Wallace ID }\end{array}$ & 1.80 & 2.69 & 7.96 & 79.0 & 95.6 & 86.9 & 75.1 & 60.4 & 92.3 \\
\hline 4 & $\begin{array}{l}\text { EF Ninemile Creek above } \\
\text { Success Mine near } \\
\text { Blackcloud ID }\end{array}$ & 0.855 & 0.481 & 1.42 & 14.8 & 9.35 & 22.6 & 14.0 & 8.36 & 22.6 \\
\hline 6 & $\begin{array}{l}\text { Ninemile Creek above } \\
\text { mouth at Wallace ID }\end{array}$ & 3.93 & 2.43 & 6.04 & 40.8 & 34.5 & 48.0 & 42.1 & 35.0 & 50.1 \\
\hline 7 & $\begin{array}{l}\text { SFCDR above Placer Creek } \\
\text { at Wallace ID }\end{array}$ & 10.6 & 6.76 & 16.0 & 132 & 111 & 155 & 129 & 109 & 152 \\
\hline 8 & $\begin{array}{l}\text { SFCDR at Elizabeth Park } \\
\text { near Kellogg ID }\end{array}$ & 42.1 & 21.7 & 76.2 & 185 & 165 & 207 & 209 & 178 & 244 \\
\hline 9 & SFCDR at Kellogg ID & 38.7 & 18.0 & 75.4 & 198 & 174 & 224 & 225 & 188 & 268 \\
\hline 10 & SFCDR at Smelterville ID & 67.4 & 33.4 & 126 & 307 & 276 & 342 & 421 & 322 & 540 \\
\hline 11 & $\begin{array}{l}\text { SFCDR above Pine Creek } \\
\text { near Pinehurst ID }\end{array}$ & 47.7 & 26.0 & 81.6 & 322 & 295 & 352 & 338 & 307 & 370 \\
\hline 16 & $\begin{array}{l}\text { St. Joe River at Ramsdell } \\
\text { near St. Maries ID }\end{array}$ & 2.93 & 1.75 & 4.66 & 17.4 & 9.16 & 30.2 & 22.3 & 11.6 & 39.3 \\
\hline 17 & $\begin{array}{l}\text { Spokane River near Coeur } \\
\text { d'Alene Lake Outlet at } \\
\text { Coeur d'Alene ID }\end{array}$ & 31.9 & 20.1 & 48.1 & 530 & 467 & 599 & 521 & 475 & 571 \\
\hline 18 & $\begin{array}{l}\text { Spokane River near } \\
\text { Post Falls ID }\end{array}$ & 42.7 & 31.2 & 57.0 & 496 & 437 & 559 & 495 & 454 & 538 \\
\hline
\end{tabular}


Table 8. Annual loads of dissolved and total cadmium, lead, and zinc and 95-percent confidence intervals for streamflow-gaging and water-quality sampling sites in the Coeur d'Alene and Spokane River Basins, northern Idaho, water years 2009-13.—Continued

[Locations of sites are shown in figure 1. Abbreviations: ton/yr, ton per year; C.I., confidence interval; NFCDR, North Fork Coeur d'Alene River; SFCDR, South Fork Coeur d'Alene River; CDR, Coeur d'Alene River; EF, East Fork; ID, Idaho]

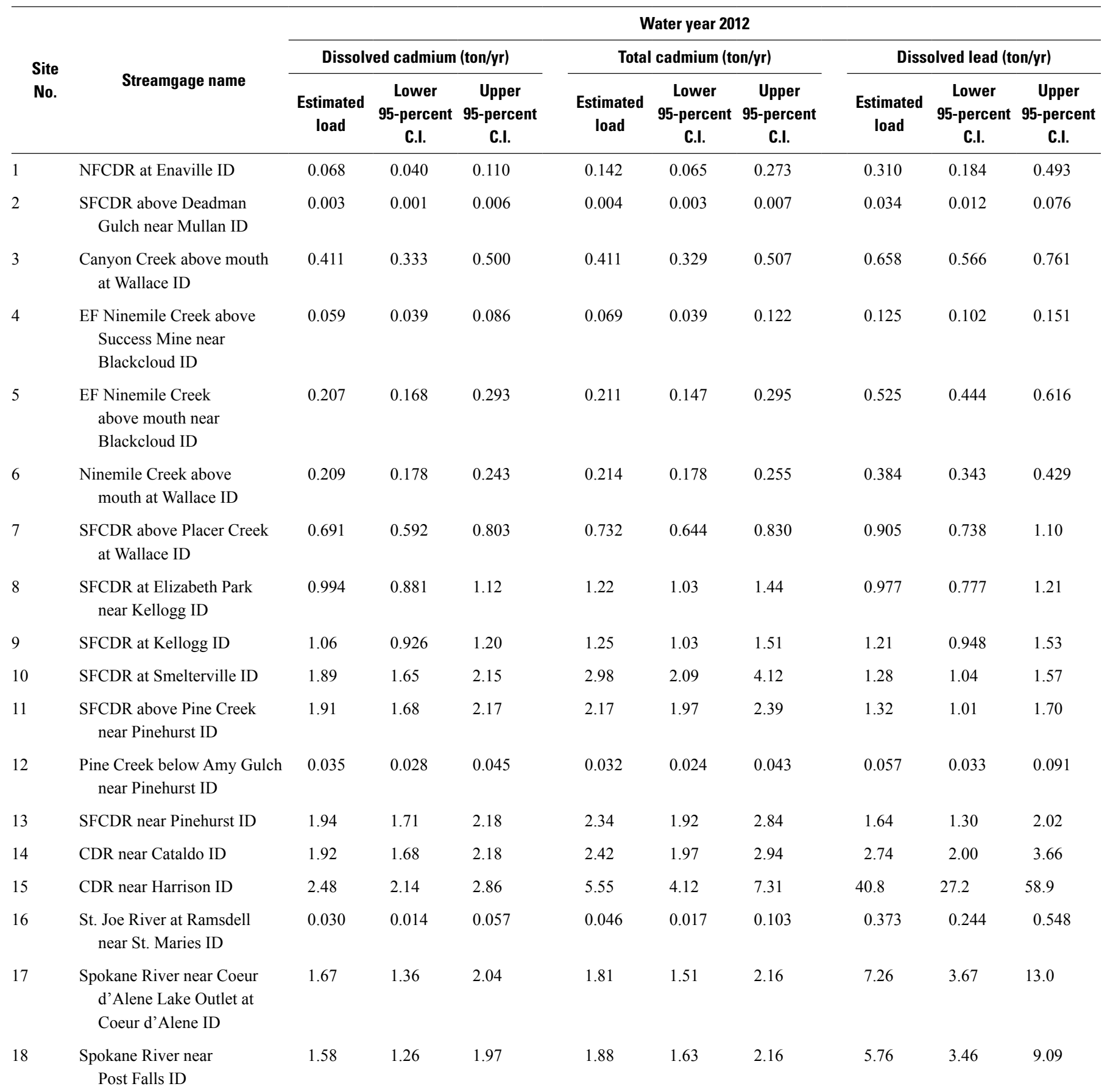


Table 8. Annual loads of dissolved and total cadmium, lead, and zinc and 95-percent confidence intervals for streamflow-gaging and water-quality sampling sites in the Coeur d'Alene and Spokane River Basins, northern Idaho, water years 2009-13.—Continued

[Locations of sites are shown in figure 1. Abbreviations: ton/yr, ton per year; C.I., confidence interval; NFCDR, North Fork Coeur d'Alene River; SFCDR, South Fork Coeur d'Alene River; CDR, Coeur d'Alene River; EF, East Fork; ID, Idaho]

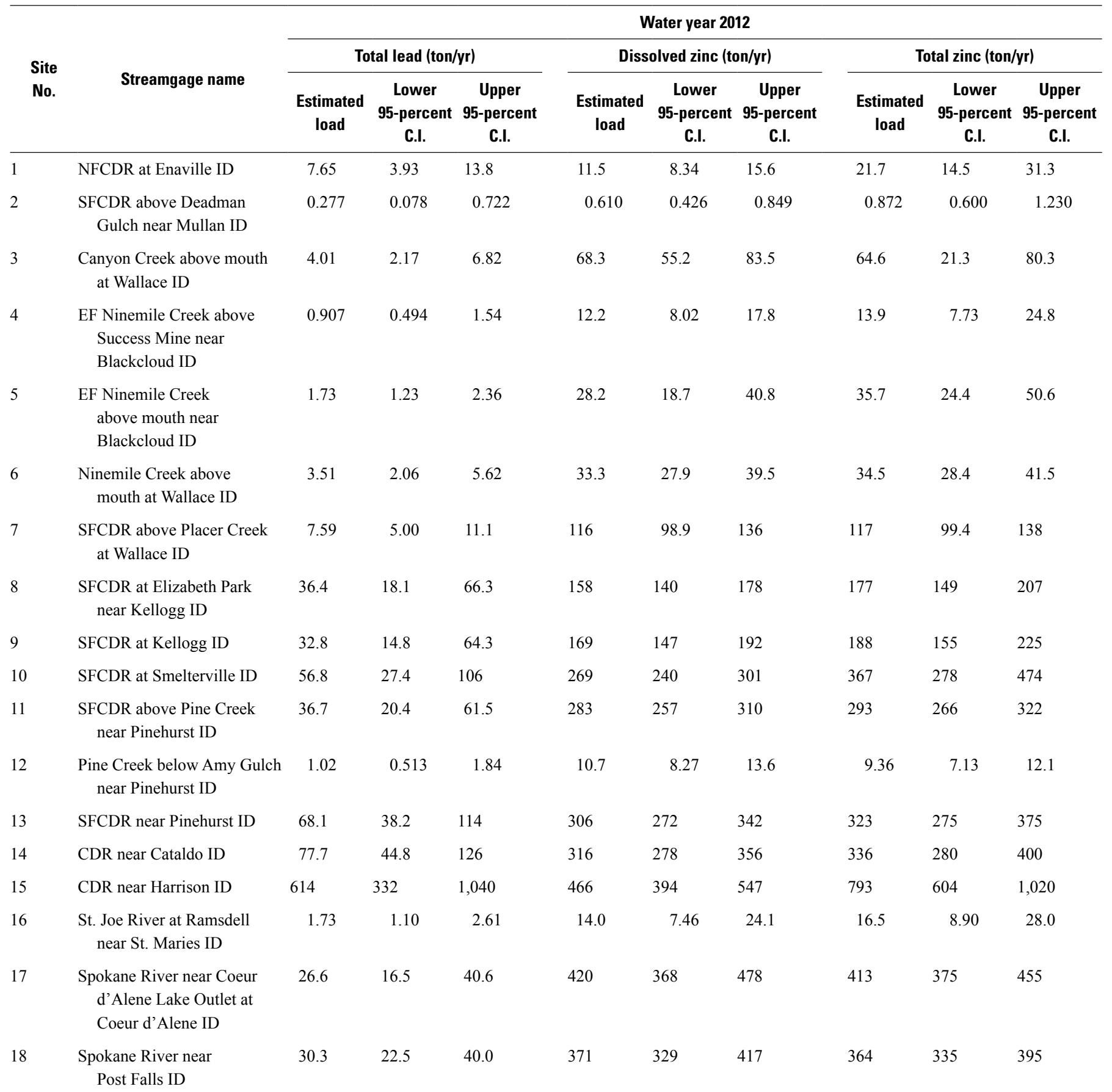


Table 8. Annual loads of dissolved and total cadmium, lead, and zinc and 95-percent confidence intervals for streamflow-gaging and water-quality sampling sites in the Coeur d'Alene and Spokane River Basins, northern Idaho, water years 2009-13.-Continued

[Locations of sites are shown in figure 1. Abbreviations: ton/yr, ton per year; C.I., confidence interval; NFCDR, North Fork Coeur d'Alene River; SFCDR, South Fork Coeur d'Alene River; CDR, Coeur d'Alene River; EF, East Fork; ID, Idaho]

\begin{tabular}{|c|c|c|c|c|c|c|c|c|c|c|}
\hline \multirow{3}{*}{$\begin{array}{l}\text { Site } \\
\text { No. }\end{array}$} & \multirow{3}{*}{ Streamgage name } & \multicolumn{9}{|c|}{ Water year 2013} \\
\hline & & \multicolumn{3}{|c|}{ Dissolved cadmium (ton/yr) } & \multicolumn{3}{|c|}{ Total cadmium (ton/yr) } & \multicolumn{3}{|c|}{ Dissolved lead (ton/yr) } \\
\hline & & $\begin{array}{l}\text { Estimated } \\
\text { load }\end{array}$ & $\begin{array}{l}\text { Lower } \\
\text { 95-percent } \\
\text { C.I. }\end{array}$ & $\begin{array}{c}\text { Upper } \\
\text { 95-percent } \\
\text { C.I. }\end{array}$ & $\begin{array}{l}\text { Estimated } \\
\text { load }\end{array}$ & $\begin{array}{l}\text { Lower } \\
\text { 95-percent } \\
\text { C.I. }\end{array}$ & $\begin{array}{c}\text { Upper } \\
\text { 95-percent } \\
\text { C.I. }\end{array}$ & $\begin{array}{l}\text { Estimated } \\
\text { load }\end{array}$ & $\begin{array}{c}\text { Lower } \\
\text { 95-percent } \\
\text { C.I. }\end{array}$ & $\begin{array}{c}\text { Upper } \\
\text { 95-percent } \\
\text { C.I. }\end{array}$ \\
\hline 1 & NFCDR at Enaville ID & 0.047 & 0.027 & 0.078 & 0.066 & 0.031 & 0.123 & 0.178 & 0.104 & 0.285 \\
\hline 3 & $\begin{array}{l}\text { Canyon Creek above mouth } \\
\text { at Wallace ID }\end{array}$ & 0.391 & 0.310 & 0.487 & 0.379 & 0.295 & 0.479 & 0.509 & 0.429 & 0.598 \\
\hline 4 & $\begin{array}{l}\text { EF Ninemile Creek above } \\
\text { Success Mine near } \\
\text { Blackcloud ID }\end{array}$ & 0.051 & 0.031 & 0.081 & 0.056 & 0.029 & 0.101 & 0.098 & 0.076 & 0.124 \\
\hline 6 & $\begin{array}{l}\text { Ninemile Creek above } \\
\text { mouth at Wallace ID }\end{array}$ & 0.162 & 0.136 & 0.193 & 0.150 & 0.123 & 0.183 & 0.278 & 0.244 & 0.315 \\
\hline 7 & $\begin{array}{l}\text { SFCDR above Placer Creek } \\
\text { at Wallace ID }\end{array}$ & 0.607 & 0.504 & 0.725 & 0.615 & 0.528 & 0.714 & 0.778 & 0.594 & 1.00 \\
\hline 8 & $\begin{array}{l}\text { SFCDR at Elizabeth Park } \\
\text { near Kellogg ID }\end{array}$ & 0.909 & 0.797 & 1.03 & 0.938 & 0.779 & 1.12 & 0.717 & 0.560 & 0.905 \\
\hline 9 & SFCDR at Kellogg ID & 0.967 & 0.834 & 1.12 & 0.940 & 0.759 & 1.15 & 0.884 & 0.671 & 1.14 \\
\hline 10 & SFCDR at Smelterville ID & 1.89 & 1.63 & 2.18 & 2.36 & 1.62 & 3.34 & 0.938 & 0.747 & 1.16 \\
\hline 11 & $\begin{array}{l}\text { SFCDR above Pine Creek } \\
\text { near Pinehurst ID }\end{array}$ & 1.73 & 1.48 & 2.00 & 1.82 & 1.63 & 2.04 & 0.831 & 0.608 & 1.11 \\
\hline 16 & $\begin{array}{l}\text { St. Joe River at Ramsdell } \\
\text { near St. Maries ID }\end{array}$ & 0.021 & 0.009 & 0.041 & 0.021 & 0.008 & 0.044 & 0.285 & 0.183 & 0.425 \\
\hline 17 & $\begin{array}{l}\text { Spokane River near Coeur } \\
\text { d'Alene Lake Outlet at } \\
\text { Coeur d'Alene ID }\end{array}$ & 1.04 & 0.848 & 1.27 & 1.12 & 0.930 & 1.33 & 2.29 & 1.36 & 4.51 \\
\hline 18 & $\begin{array}{l}\text { Spokane River near } \\
\text { Post Falls ID }\end{array}$ & 1.06 & 0.843 & 1.32 & 1.13 & 0.966 & 1.31 & 1.62 & 1.00 & 2.50 \\
\hline
\end{tabular}


Table 8. Annual loads of dissolved and total cadmium, lead, and zinc and 95-percent confidence intervals for streamflow-gaging and water-quality sampling sites in the Coeur d'Alene and Spokane River Basins, northern Idaho, water years 2009-13.—Continued

[Locations of sites are shown in figure 1. Abbreviations: ton/yr, ton per year; C.I., confidence interval; NFCDR, North Fork Coeur d'Alene River; SFCDR, South Fork Coeur d'Alene River; CDR, Coeur d'Alene River; EF, East Fork; ID, Idaho]

\begin{tabular}{|c|c|c|c|c|c|c|c|c|c|c|}
\hline \multirow{3}{*}{$\begin{array}{l}\text { Site } \\
\text { No. }\end{array}$} & \multirow{3}{*}{ Streamgage name } & \multicolumn{9}{|c|}{ Water year 2013} \\
\hline & & \multicolumn{3}{|c|}{ Total lead (ton/yr) } & \multicolumn{3}{|c|}{ Dissolved zinc (ton/yr) } & \multicolumn{3}{|c|}{ Total zinc (ton/yr) } \\
\hline & & $\begin{array}{c}\text { Estimated } \\
\text { load }\end{array}$ & $\begin{array}{c}\text { Lower } \\
\text { 95-percent } \\
\text { C.I. }\end{array}$ & $\begin{array}{c}\text { Upper } \\
\text { 95-percent } \\
\text { C.I. }\end{array}$ & $\begin{array}{c}\text { Estimated } \\
\text { load }\end{array}$ & $\begin{array}{l}\text { Lower } \\
\text { 95-percent } \\
\text { C.I. }\end{array}$ & $\begin{array}{c}\text { Upper } \\
\text { 95-percent } \\
\text { C.I. }\end{array}$ & $\begin{array}{c}\text { Estimated } \\
\text { load }\end{array}$ & $\begin{array}{c}\text { Lower } \\
\text { 95-percent } \\
\text { C.I. }\end{array}$ & $\begin{array}{l}\text { Upper } \\
\text { 95-percent } \\
\text { C.I. }\end{array}$ \\
\hline 1 & NFCDR at Enaville ID & 2.11 & 1.15 & 3.58 & 8.47 & 5.99 & 11.7 & 11.9 & 8.01 & 17.0 \\
\hline 3 & $\begin{array}{l}\text { Canyon Creek above mouth } \\
\text { at Wallace ID }\end{array}$ & 2.51 & 1.30 & 4.39 & 66.6 & 52.5 & 83.3 & 60.8 & 47.0 & 77.4 \\
\hline 4 & $\begin{array}{l}\text { EF Ninemile Creek above } \\
\text { Success Mine near } \\
\text { Blackcloud ID }\end{array}$ & 0.600 & 0.296 & 1.10 & 10.7 & 6.31 & 17.1 & 11.2 & 5.82 & 20.2 \\
\hline 6 & $\begin{array}{l}\text { Ninemile Creek above } \\
\text { mouth at Wallace ID }\end{array}$ & 1.14 & 0.711 & 1.74 & 25.2 & 20.6 & 30.6 & 24.0 & 19.4 & 29.5 \\
\hline 7 & $\begin{array}{l}\text { SFCDR above Placer Creek } \\
\text { at Wallace ID }\end{array}$ & 3.77 & 2.37 & 5.74 & 102 & 83.8 & 123 & 99.5 & 82.0 & 120 \\
\hline 8 & $\begin{array}{l}\text { SFCDR at Elizabeth Park } \\
\text { near Kellogg ID }\end{array}$ & 11.5 & 6.27 & 19.5 & 144 & 156 & 164 & 136 & 114 & 162 \\
\hline 9 & SFCDR at Kellogg ID & 11.8 & 5.69 & 21.7 & 154 & 132 & 178 & 140 & 114 & 171 \\
\hline 10 & SFCDR at Smelterville ID & 18.7 & 9.92 & 32.1 & 261 & 230 & 295 & 287 & 213 & 378 \\
\hline 11 & $\begin{array}{l}\text { SFCDR above Pine Creek } \\
\text { near Pinehurst ID }\end{array}$ & 13.3 & 7.34 & 22.2 & 254 & 227 & 283 & 249 & 221 & 278 \\
\hline 16 & $\begin{array}{l}\text { St. Joe River at Ramsdell } \\
\text { near St. Maries ID }\end{array}$ & 0.760 & 0.492 & 1.12 & 10.1 & 5.32 & 17.6 & 9.27 & 5.08 & 15.6 \\
\hline 17 & $\begin{array}{l}\text { Spokane River near Coeur } \\
\text { d'Alene Lake Outlet at } \\
\text { Coeur d'Alene ID }\end{array}$ & 8.81 & 5.61 & 13.2 & 282 & 247 & 320 & 271 & 245 & 298 \\
\hline 18 & $\begin{array}{l}\text { Spokane River near } \\
\text { Post Falls ID }\end{array}$ & 7.88 & 5.94 & 10.3 & 271 & 239 & 306 & 248 & 227 & 271 \\
\hline
\end{tabular}


Table 8. Annual loads of dissolved and total cadmium, lead, and zinc and 95-percent confidence intervals for streamflow-gaging and water-quality sampling sites in the Coeur d'Alene and Spokane River Basins, northern Idaho, water years 2009-13.—Continued

[Locations of sites are shown in figure 1. Abbreviations: ton/yr, ton per year; C.I., confidence interval; NFCDR, North Fork Coeur d'Alene River; SFCDR, South Fork Coeur d'Alene River; CDR, Coeur d'Alene River; EF, East Fork; ID, Idaho]

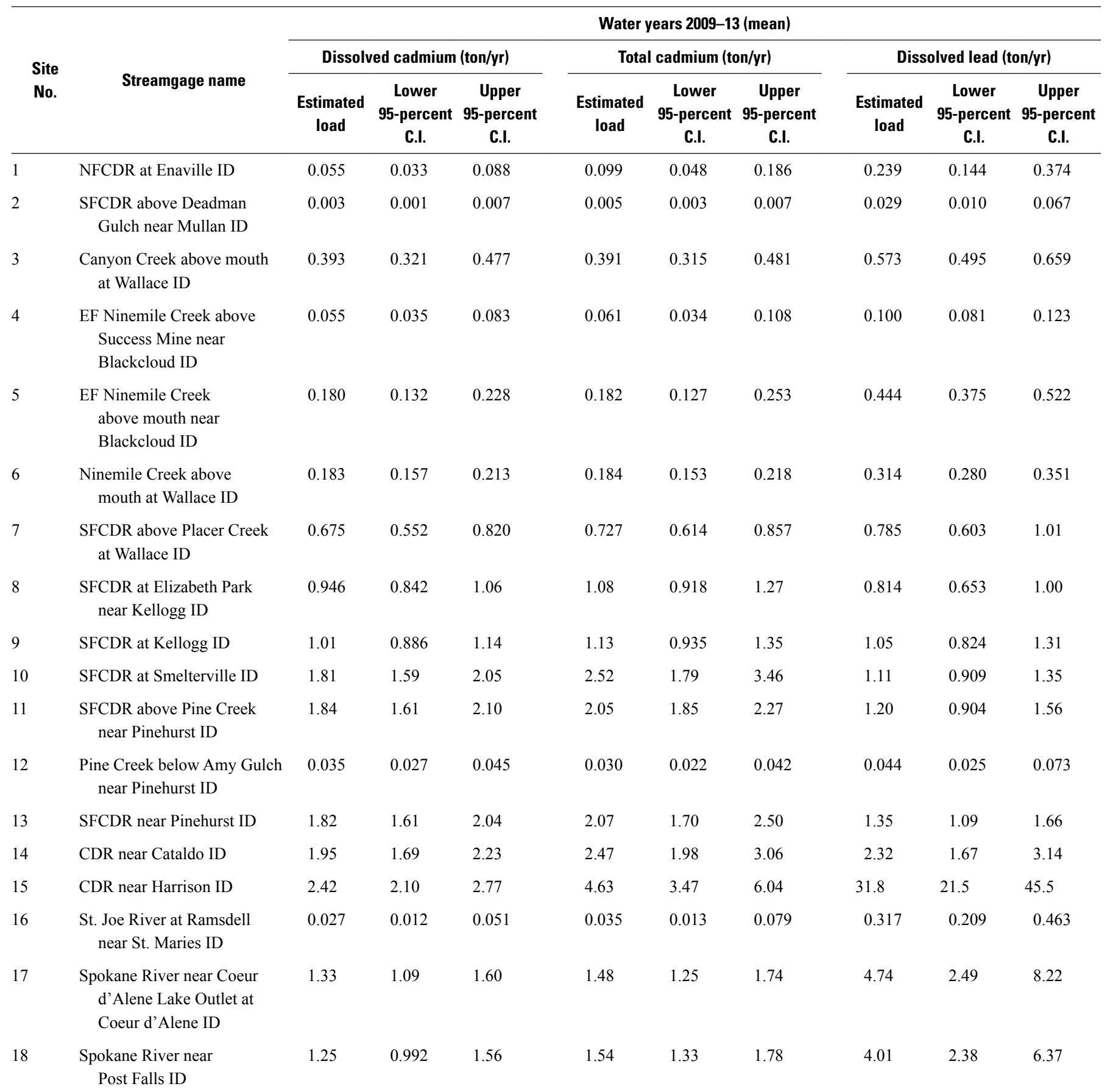


Table 8. Annual loads of dissolved and total cadmium, lead, and zinc and 95-percent confidence intervals for streamflow-gaging and water-quality sampling sites in the Coeur d'Alene and Spokane River Basins, northern Idaho, water years 2009-13. - Continued

[Locations of sites are shown in figure 1. Abbreviations: ton/yr, ton per year; C.I., confidence interval; NFCDR, North Fork Coeur d'Alene River; SFCDR, South Fork Coeur d'Alene River; CDR, Coeur d'Alene River; EF, East Fork; ID, Idaho]

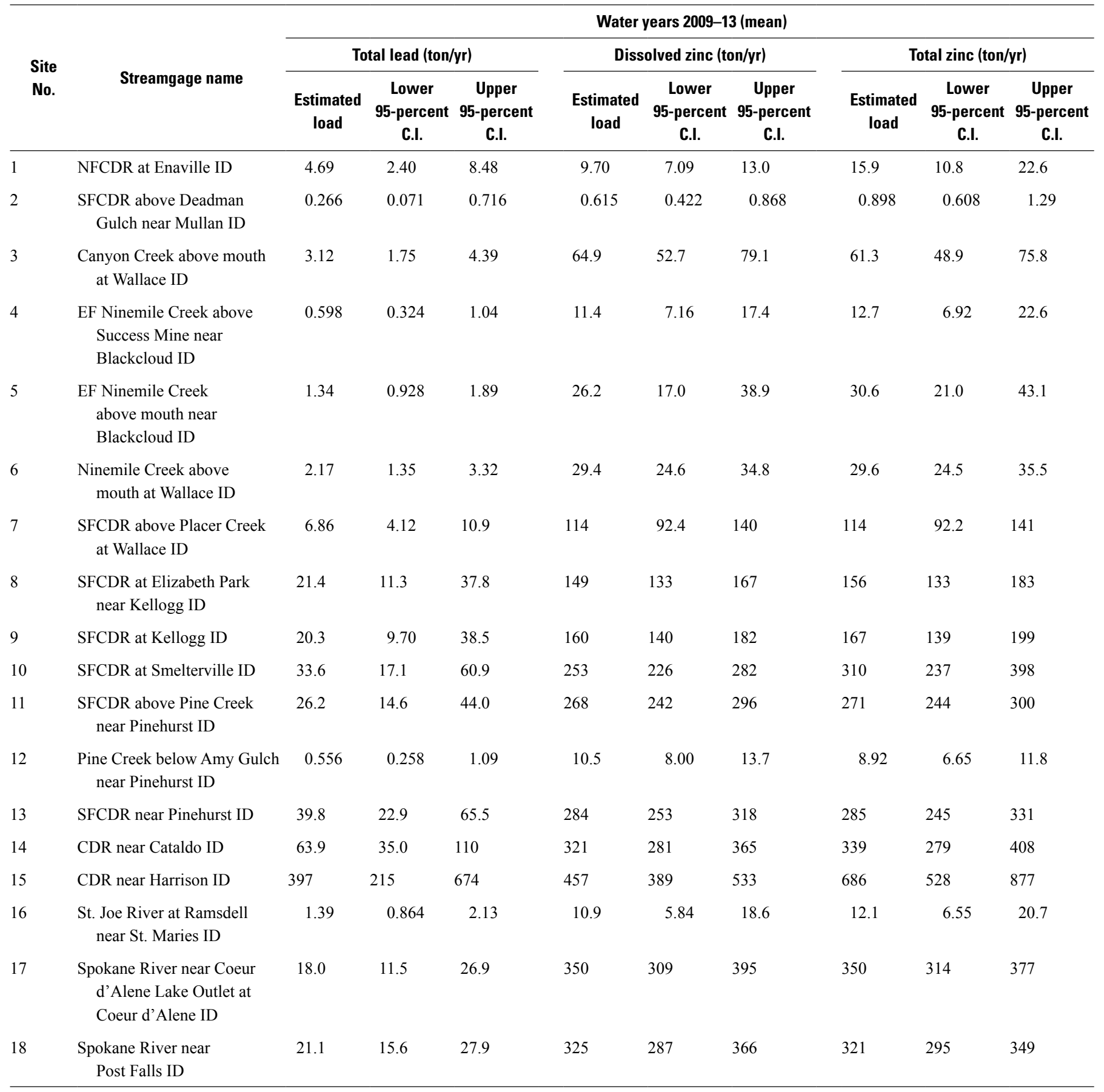



Publishing support provided by the U.S. Geological Survey Science Publishing Network, Tacoma Publishing Service Center

For more information concerning the research in this report, contact the Director, Idaho Water Science Center

U.S. Geological Survey

230 Collins Road

Boise, Idaho 83702

http://id.water.usgs.gov 


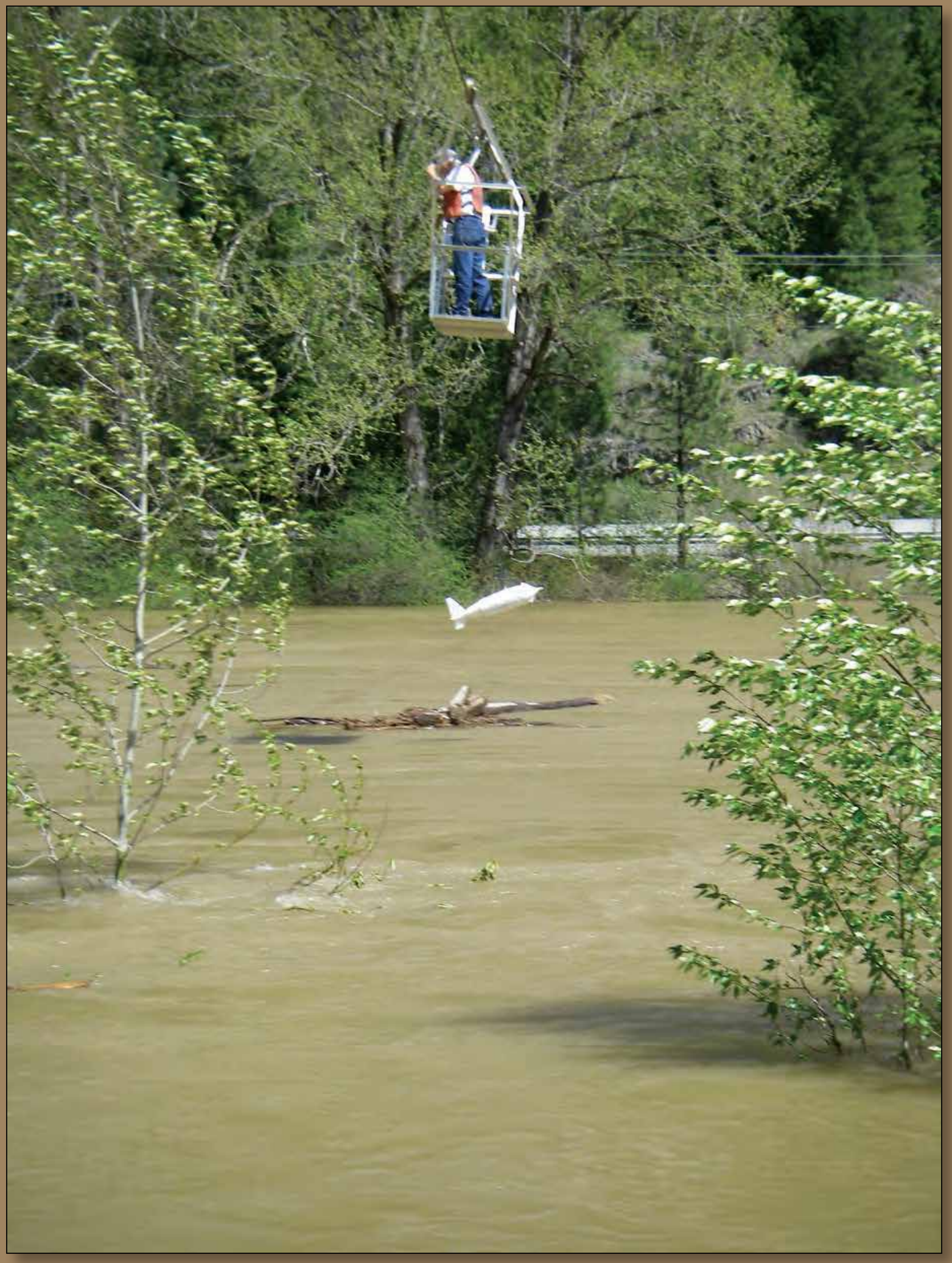

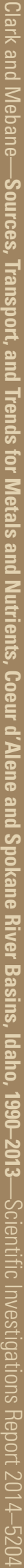

